\title{
5. SITE 497: MIDDLE AMERICA TRENCH UPPER SLOPE ${ }^{1}$
}

\author{
Shipboard Scientific Party ${ }^{2}$
}

\section{HOLE 497}

Date occupied: 1 June 1979

Date departed: 5 June 1979

Time on hole: 92.6 hours

Position: $12^{\circ} 59.23^{\prime} \mathrm{N}$; $90^{\circ} 49.68^{\prime} \mathrm{W}$

Water depth (sea level; corrected m, echo-sounding): 2347

Water depth (rig floor; corrected m, echo-sounding): 2357

Bottom felt (m, drill pipe): 2358

Penetration (m): 396.5

Number of cores: 42

Total length of cored section (m): 396.5

Total core recovered (m): 224.57

Core recovery $(\%): 56.6$

Oldest sediment cored:

Depth sub-bottom (m): 396.5

Nature: Nannofossil mudstone

Age: Early Pliocene

Basement: Not reached

Principal results: As at Site 496, Site 497 was also abandoned about 500 meters short of the primary objective because of gas hydrates. Once again that objective was a landward-dipping reflector thought to represent an imbricate thrust slice. As at Site 496, Quaternary olive gray diatomaceous mud overlies a section of Pliocene sand, pebbly mud, limestone, and mudstone, and near-vertical, darkcolored veinlets occur in the lower, more lithified unit. The Pliocene section, however, is much thicker at Site 497 than at Site 496.

Quaternary and Pliocene microfossils are abundant at Site 497, and there are no unusual age discrepancies. The pebbly mudstones of the lower unit correspond to times of rapid sedimentation. Physical properties distinguish the three lithologic units cored at this site.

\footnotetext{
${ }^{1}$ Aubouin, J., von Huene, R., et al., Inits. Repts. DSDP, 67: Washington (U.S. Govt. Printing Office).

2 Roland von Huene (Co-Chief Scientist), U.S. Geological Survey, Menlo Park, California; Jean Aubouin (Co-Chief Scientist), Départment de Géologie Structurale, Université Pierre et Marie Curie, Paris, France: Jacques Azéma, Départment de Géologie Structurale. Université Pierre et Marie Curie, Paris, France; Grant Blackinton, Hawaii Institute of Geophysics, University of Hawaii, Honolulu, Hawaii; Jerry A. Carter, Hawaii Institute of Geo physics, University of Hawaii, Honolulu, Hawaii; William T. Coulbourn, Deep Sea Drilling Project, Scripps Institution of Oceanography, La Jolla, California; Darrel S. Cowan, Department of Geological Sciences, University of Washington, Seatle, Washington: Joseph A. Curi-

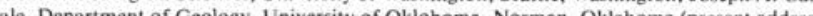
ale, Department of Geolo Union Oil Company of California, P.O. Box 76, Brea, Ca.): Carlos A. Dengo, Department of Geology and Tectonophysics, Texas A\&M University, College Station. Texas; Richard W Faas, Department of Geology. Lafayette College, Easton, Pennsylvania; William Harrison, Department of Geology, University of Oklahoma, Norman, Oklahoma (present address: Union Oil Company of California, P.O. Box 76, Brea, Ca.); Reinhard Hesse, Lehrstuhl fiir Geologie, Technische Universität, Münich, Federal Republic of Germany, and Department of Geological Sciences, McGill University, Montreal, Quebec, Canada: Donald M. Hussong, Hawaii Institute of Geophysies, University of Hawaii, Honolulu, Hawaiis John W. Ladd. The

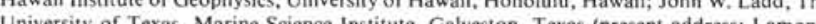
Universily of Texas, Marine Scicice Institute, Galveston, Texas (present address: Doherty Geological Observatory, Palisades, New York): Nikita Muzylöv, Geological Institute, U.S.S.R. Academy of Sciences, Moscow, U.S.S.R.; Tsunemasa Shiki, Department of Geology and Mineralogy, Faculty of Science, Kyoto University, Kyoto, Japan; Peter R. Thompson, Lamont-Doherty Geological Observatory, Palisades, New York; and Jean Westberg, Geological Research Division, Scripps Institution of Oceanography, La Jolla, California,
}

Gas hydrates necessitated that the site be abandoned. The methane/ethane ratio in pieces of frozen vitric sand were higher than at equivalent depths at Site 496. Variation of this ratio between sites and the variation of trace amounts of heavier hydrocarbons indicate local variability of hydrocarbon composition.

\section{BACKGROUND AND OBJECTIVES}

Site 497 is situated in the upper trench slope in about 2350 meters of water, 3650 meters above and $42 \mathrm{~km}$ from the trench axis (Fig. 1). The site was selected during the voyage to achieve objectives not met at Site 496, specifically the sampling of a landward-dipping horizon masking a high-velocity substance at depth. A similar landward-dipping reflection recorded in seismic record GUA-13 at about 1000 meters sub-bottom depth at Site 497 is thought to represent a horizon immediately overlying the target represented at Site 496. At no other locale along the Guatemala transect is the landward-dipping reflection within reach of the Glomar Challenger capability. In addition, it appears that the part of the slope apron not recovered at 496 is present at a shallower depth at 497 . In short, the objectives at Site 497 were to document the chronology of development of the margin and to determine the rock and sediment types of which this margin is composed, to obtain well logs that might refine the interpretation of seismic reflection records, and to link the geology on land to the geology of the trench slope.

\section{OPERATIONS}

Glomar Challenger departed Site 496 on June 1 at 1455. Permission had been granted by radio only a few hours earlier to occupy Site 497 . The beacon was dropped at 1642 during the first pass over Site 497. The drill string was lowered, and the first core was recovered on June 2 at 0136 (Table 1).

After coring to a sub-bottom depth of 396.5 meters, this hole was abandoned because of gas hydrate. Logging was partially successful; formation density and caliper and temperature logs were obtained. The hole was cemented prior to departure.

\section{LITHOSTRATIGRAPHY}

\section{Introduction}

Site 497 , located $8 \mathrm{~km}$ seaward of Site 496 , is on the midslope in water 2350 meters deep. Drilling penetrated 396.5 meters of lower Pliocene to Quaternary sediments. On the basis of the sedimentary characteristics, three units can be distinguished (Fig. 2). These units roughly correspond to the first unit drilled at Site 496. 


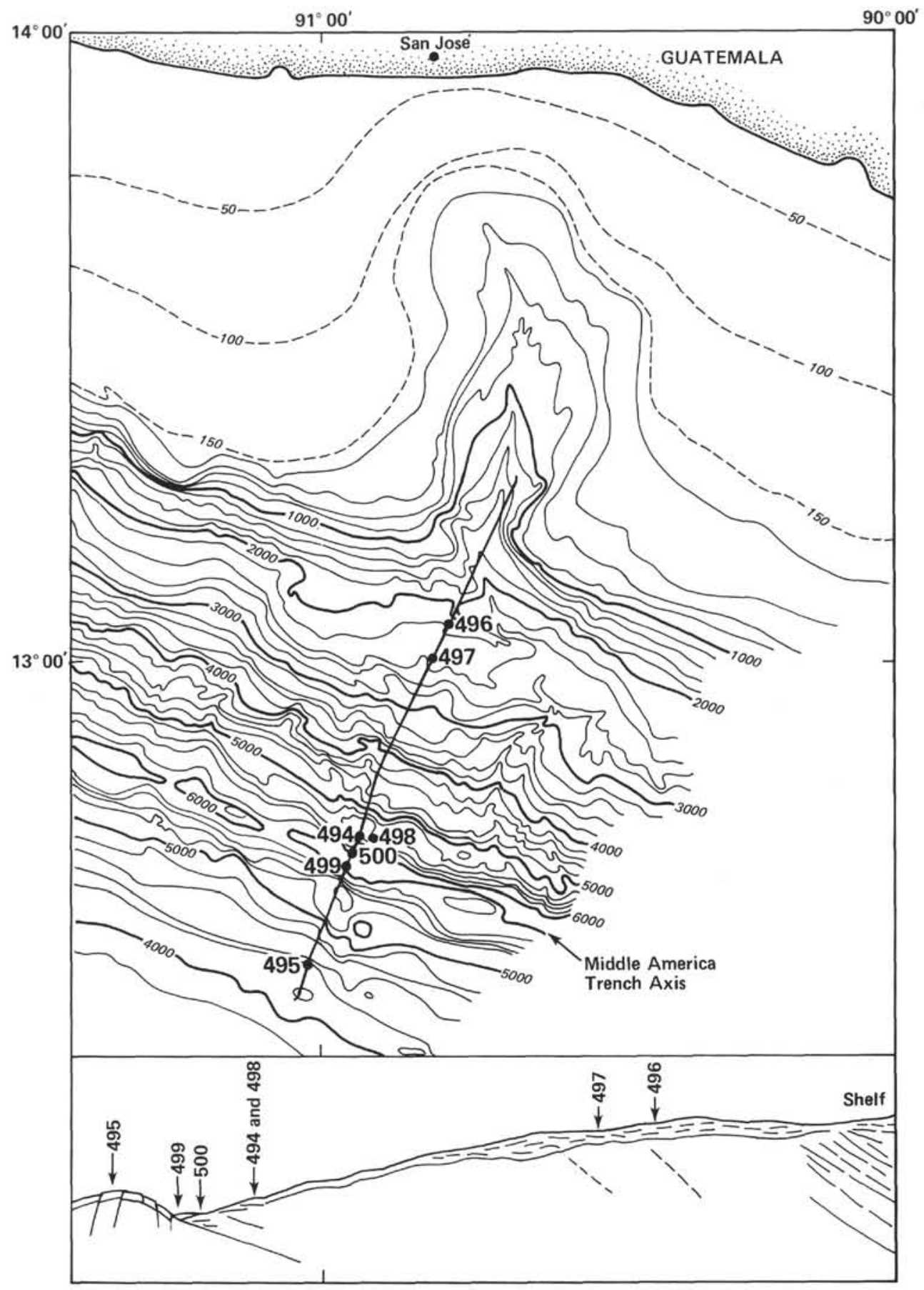

Figure 1. Location map and cross section showing position of Site 497.

\section{Unit 1 (Cores 1 to $16 ; 0.0-149.5 \mathrm{~m}$ sub-bottom depth; Quaternary)}

The sediments of Unit 1 are predominantly olive gray (5Y 3/2) mud with some lighter-shaded (5Y 4/2) parts and are soft enough throughout to have been swirled by drilling. Clay minerals and minor volcanic glass are the terrigenous and eolian components; nannofossils, diatoms, and other microfossils make up the biogenic component and may attain proportions up to $45 \%$. The lighter-colored part seems slightly more glassy or diatoma- ceous and poor in clay minerals. Thin layers $(0.5-2 \mathrm{~cm})$ and patches (1-3 cm in size) of dark colored (N5, 5Y $2.5 / 1$ ) ash, many deformed into irregular blobs by drilling, as well as glassy sand and glauconitic sand are interbedded in some cores (Cores 7, 9, 13, 14). Small spots $(0.5-2 \mathrm{~cm})$ of white, pale gray, or olive gray ash are also present in many of the cores of this unit. Shell fragments were found in mud of Cores 2, 7, and 9, a scaphopod (5 $\mathrm{cm}$ long) in Core 1, and a wood fragment in Core 15 .

Disturbed sedimentary features are characteristic; the sediment is soupy in many cores, especially those cores 
Table 1. Coring summary for Hole 497

\begin{tabular}{|c|c|c|c|c|c|c|c|}
\hline Core No. & $\begin{array}{c}\text { Date } \\
\text { (June, 1979) }\end{array}$ & $\begin{array}{l}\text { Local Time } \\
\text { (L) }\end{array}$ & $\begin{array}{l}\text { Depth from } \\
\text { Drill Floor } \\
\text { (m; top-bottom) }\end{array}$ & $\begin{array}{c}\text { Sub-bottom } \\
\text { Depth } \\
\text { (m; top-bottom) }\end{array}$ & $\begin{array}{l}\text { Length } \\
\text { Cored } \\
\text { (m) }\end{array}$ & $\begin{array}{l}\text { Length } \\
\text { Recovered } \\
\text { (m) }\end{array}$ & $\begin{array}{c}\text { Recovery } \\
(\%)\end{array}$ \\
\hline 1 & 2 & 0136 & $2358.0-2365.0$ & $0.0-7.0$ & 7.0 & 6.65 & 95 \\
\hline 2 & 2 & 0229 & $2365.0-2374.5$ & $7.0-16.5$ & 9.5 & 9.02 & 95 \\
\hline 3 & 2 & 0313 & $2374.5-2384.0$ & $16.6-26.0$ & 9.5 & 4.05 & 43 \\
\hline 4 & 2 & 0405 & $2384.0-2393.5$ & $26.0-35.5$ & 9.5 & 1.38 & 14 \\
\hline 5 & 2 & 0454 & $2393.5-2403.0$ & $35.5-45.0$ & 9.5 & 4.64 & 49 \\
\hline 6 & 2 & 0543 & $2403.0-2412.5$ & $45.0-54.5$ & 9.5 & 0.69 & 7 \\
\hline 7 & 2 & 0638 & $2412.5-2422.0$ & $54.5-64.0$ & 9.5 & 7.95 & 84 \\
\hline 8 & 2 & 0808 & $2422.0-2431.5$ & $64.0-73.5$ & 9.5 & 0.05 & $>1$ \\
\hline 9 & 2 & 0904 & $2431.5-2441.0$ & $73.5-83,0$ & 9.5 & 5.85 & 55 \\
\hline 10 & 2 & 1005 & $2441.0-2450.5$ & $83.0-92.5$ & 9.5 & 5.25 & 50 \\
\hline 11 & 2 & 1058 & $2450.5-2460.0$ & $92.5-102.0$ & 9.5 & 3.70 & 39 \\
\hline 12 & 2 & 1154 & $2460.0-2469.5$ & $102.0-111.5$ & 9.5 & 8.46 & 89 \\
\hline 13 & 2 & 1256 & $2469.5-2479.0$ & $111.5-121.0$ & 9.5 & 7.76 & 82 \\
\hline 14 & 2 & 1400 & $2479.0-2488.5$ & $121.0-130.5$ & 9.5 & 3.16 & 33 \\
\hline 15 & 2 & 1500 & $2488.5-2498.0$ & $130.5-140.0$ & 9.5 & 8.75 & 92 \\
\hline 16 & 2 & 1607 & $2498.0-2507.5$ & $140.0-149.5$ & 9.5 & 9.25 & 97 \\
\hline 17 & 2 & 1709 & $2507.5-2517.0$ & $149.5-159.0$ & 9.5 & 3.94 & 41 \\
\hline 18 & 2 & 1814 & $2517.0-2526.0$ & $159.0-168.5$ & 9.5 & 6.21 & 65 \\
\hline 19 & 2 & 1913 & $2526.0-2536.0$ & $168.5-178.0$ & 9.5 & 5.88 & 62 \\
\hline 20 & 2 & 2015 & $2536.0-2545.5$ & $178.0-187.5$ & 9.5 & 5.18 & 54 \\
\hline 21 & 2 & 2115 & $2545.5-2555.0$ & $187.5-197.0$ & 9.5 & 0.0 & 0 \\
\hline 22 & 2 & 2220 & $2555.0-2564.5$ & $197.0-206.5$ & 9.5 & 0.0 & 0 \\
\hline 23 & 2 & 2323 & $2564.5-2574.0$ & $206.5-216.0$ & 9.5 & 3.73 & 39 \\
\hline 24 & 3 & 0047 & $2574.0-2583.5$ & $216.0-225.5$ & 9.5 & 5.00 & 53 \\
\hline 25 & 3 & 0154 & $2583.5-2593.0$ & $225.5-235.0$ & 9.5 & 4.26 & 45 \\
\hline 26 & 3 & 0305 & $2593.0-2602.5$ & $235.0-244.5$ & 9.5 & 3.94 & 41 \\
\hline 27 & 3 & 0402 & $2602.5-2612.0$ & $244.5-254.0$ & 9.5 & 3.39 & 36 \\
\hline 28 & 3 & 0508 & $2612.0-2621.5$ & $254.0-263.5$ & 9.5 & 7.96 & 84 \\
\hline 29 & 3 & 0610 & $2621.5-2631.0$ & $263.5-273.0$ & 9.5 & 9.75 & 100 \\
\hline 30 & 3 & 0719 & $2631.0-2640.5$ & $273.0-282.5$ & 9.5 & 10.03 & 100 \\
\hline 31 & 3 & 0816 & $2640.5-2650.0$ & $282.5-292.0$ & 9.5 & 8.55 & 90 \\
\hline 32 & 3 & 0923 & $2650.0-2659.5$ & $292.0-301.5$ & 9.5 & 1.49 & 16 \\
\hline 33 & 3 & 1024 & $2659.5-2669.0$ & $301.5-311.0$ & 9.5 & 0.15 & 2 \\
\hline 34 & 3 & 1149 & $2669.0-2678.5$ & $311.0-320.5$ & 9.5 & 3.90 & 41 \\
\hline 35 & 3 & 1249 & $2678.5-2688.0$ & $320.5-330.0$ & 9.5 & 7.68 & 81 \\
\hline 36 & 3 & 1416 & $2688.0-2697.5$ & $330.0-339.5$ & 9.5 & 8.42 & 89 \\
\hline 37 & 3 & 1528 & $2697.5-2707.0$ & $339.5-349.0$ & 9.5 & 5.86 & 62 \\
\hline 38 & 3 & 1640 & $2707.0-2716.5$ & $349.0-358.5$ & 9.5 & 7,40 & 78 \\
\hline 39 & 3 & 1806 & $2716.5-2726.0$ & $358.5-368.0$ & 9.5 & 7.34 & 77 \\
\hline 40 & 3 & 1907 & $2726.0-2735.5$ & $368.0-377.5$ & 9.5 & 6.82 & 72 \\
\hline 41 & 3 & 2024 & $2735.5-2745.0$ & $377.5-387.0$ & 9.5 & 4.20 & 44 \\
\hline 42 & 3 & 2145 & $2745.0-2754.5$ & $387.0-396.5$ & 9.5 & 6.91 & 73 \\
\hline
\end{tabular}

from the upper part of this unit. Laminations and mottling are discernable. Degassing phenomena, such as bubbling and small tension cracks, are common on sliced surfaces of the cores, especially in the middle part of this unit.

\section{Unit 2 (Cores 17 to 24, Section 1; 149.5-217 m sub- bottom depth; upper Pliocene and/or Quaternary)}

This unit can be distinguished from Unit 1 by frequent intercalation of sandy and pebbly layers, higher induration of the muddy sediments recovered, and the appearance of veinlets.

Intraformational pebbly mud, more than 2 meters thick, is present in Core 23 . That mud includes variably shaped clasts up to $4 \mathrm{~cm}$ in diameter. Drilling fragments of olive gray (5Y 4/2) semifirm mudstone are abundant in the much softer matrix of dark olive gray (5Y $3 / 2)$ mud. Some clasts are prolate and are well-rounded. A similar intraformational pebbly mud was recovered in Core 24 , and the base of the pebbly mud layer is selected as the base of Unit 2. Pebbly mudstone may have been lost from Cores 21 and 22; both were recovered entirely void.

Coarse-grained sand layers include pecten valves, scaphopods, microgastropods, benthic foraminifers, pumice fragments, quartz grains, and pyrite. Benthic fossils contained in these sand layers, together with pebbly muds, indicate rapid transportation of terrigenous sediments from a shallow-water environment.

The muddy sediments of Units 1 and 2 are similar in color and constituents, except that nannofossil-rich sediments were not found in Unit 2, and the upper part of this unit is somewhat diatomaceous. Spots or small patches of white and light gray ash, and a black spot, rich in opaque minerals, occur in Unit 2. Core 19 includes a pebble of very fine-grained, altered, felsic, gray, volcanic rock, composed of K-feldspar, quartz, sericitic mica, and pyrite.

The character of disturbance in Unit 2 is somewhat different from that in Unit 1 because Unit 2 sediment is more indurated. Veinlets, features identical to those in Cores 30-37 of Site 496, first occur in Core 17, the uppermost core of Unit 2. Biscuits of dark olive gray (5Y $3 / 2$ ) mudstone with anastomosing darker veinlets appear in Cores 17, 18,19,20, and 23, though some of them are poorly formed.

Unit 3 (Core 24, Section 1-Core 42; 217-396.5 m subbottom depth; lower to upper Pliocene)

The absence of coarse-grained layers distinguishes Unit 3 from Unit 2. This unit is dominated by a dark olive gray (5Y 3/2) and olive gray (5Y 4/2) semi-indurated mudstone that resembles mud of Units 1 and 2 in color and constituents. The mudstones in this unit are generally poor in fossils, but in some parts (Cores 26-29 and $40-42$ ) are nannofossiliferous and somewhat lighter colored.

A variety of components are scattered throughout the unit. A hard, white to pale gray or pale olive gray (5Y $8 / 1$ ), micritic limestone is intercalated in the upper and the lower parts of this unit (Cores 26 and 36). Several

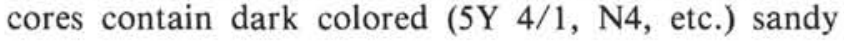




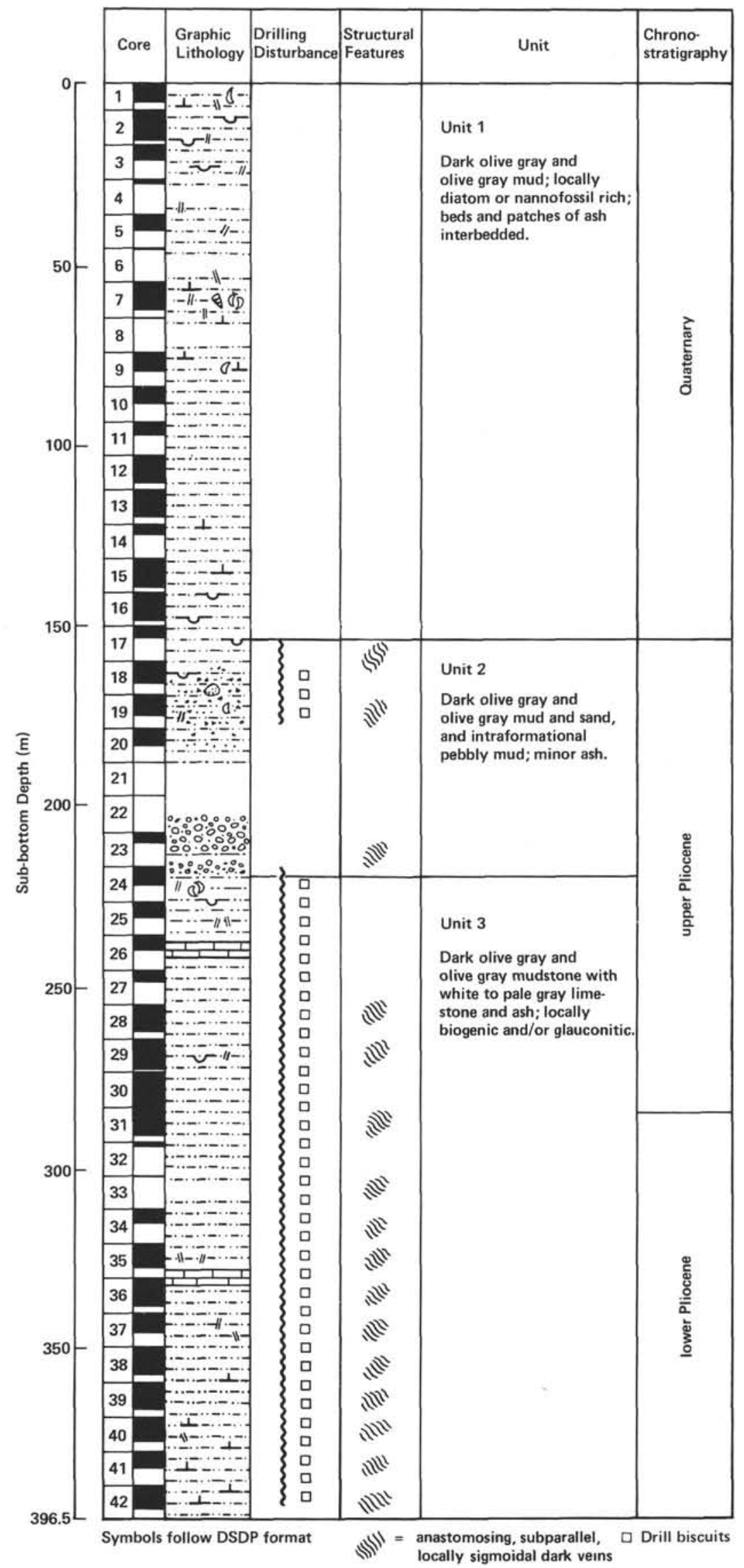

Figure 2. Summary lithologic column for Site 497. 
layers, volcanic sand layers, and white patches of vitric ash. A few layers attain more than $10-\mathrm{cm}$ thickness. The light color and layers and pebbly mud characteristic of Unit 2 are not found in Unit 3, except for local thin layers of very fine sand observed in some drilling biscuits. Other minor constituents include fragments of brown fibrous wood $(2 \times 3 \mathrm{~cm})$ in Core 38 and scattered glauconite grains in the lowermost part of Unit 3 (Cores 35, 40, 41, and 42).

\section{Summary}

The dominant lithology of the cores at Site 497 is dark olive gray to olive gray hemipelagic to hemiterrigenous mud and mudstone, containing various microfossil groups. Three lithologic units are distinguished on the basis of the coarse-grained sediments in the middle part of the sequence.

Unit 1 is Quaternary; Unit 3 is lower to upper Pliocene, and Unit 2 is a product of rapid sedimentation in a very short period around the boundary between the Pliocene and Pleistocene.

Sets of parallel and sigmoidal dark veins, analogous to structure at Site 496, are abundant in and below Section 1 of Core 25 . These are interpreted as dewatering conduits, and their consistent, approximately vertical orientation suggests they formed in a nonhydrostatic stress field.

\section{PHYSICAL PROPERTIES}

\section{Bulk Density and Water Content}

Bulk density (Fig. 3) generally increases with depth, with greatest variability in the gas-charged interval between 60 to 270 meters. Large numbers of voids and fissures indicate disturbance by the expansion of gas upon removal from in situ pressures and temperatures.

Bulk density reaches its maximum at 290 meters (Core 30 ) and remains relatively constant at $1.60 \mathrm{Mg} / \mathrm{m}^{3}$ to the base of the hole. That maximum might mark a different sedimentary unit, however, the generalized stratigraphy indicates that a lithologic break occurs in Core 24, Section 1 at about 220 meters (Fig. 2). The position of this latter boundary is not clearly observed in the mass properties.

Water content decreases sharply from the surface down to 60 meters and then more gradually to the base of the hole. Considerable variation was seen in this parameter, generally attributable to the disturbing effects of the gas expansion in the sediment while in the core barrel.

The general effect of the gas was the creation of a wider variation in these bulk properties than normally attributable to lithologic changes and/or drilling disturbance. The "blurring" effect was especially noticeable on GRAPE records, causing difficulty in selecting a "best-fit" line of average density.

\section{Sound Velocity}

Although numerous attempts were made to measure sound velocity at the site, efforts were unsuccessful until

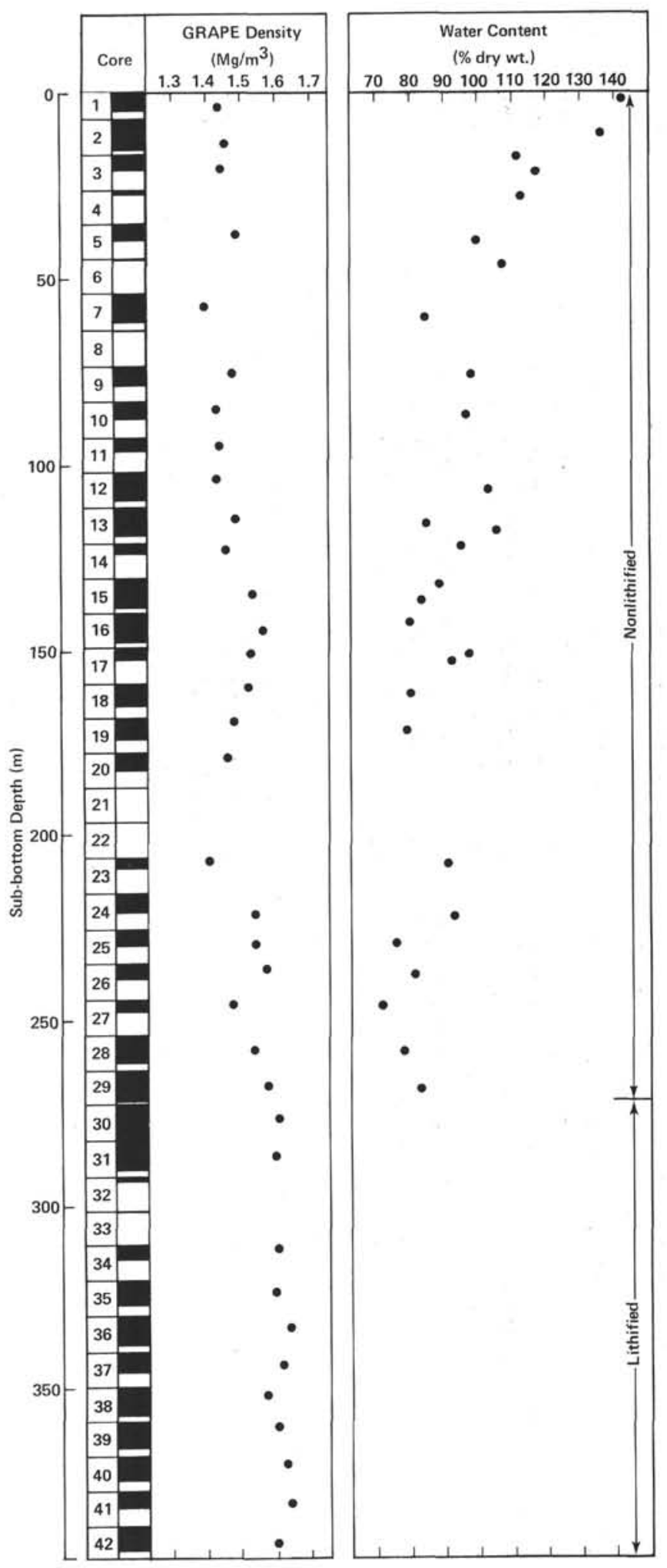

Figure 3. GRAPE density and water content profile for Site 497. 
lithified rock was encountered. Four velocity measurements indicated the following:

\begin{tabular}{cccc}
\hline Core & Section & Interval $(\mathrm{cm})$ & $V_{p}(\mathrm{~km} / \mathrm{s})$ \\
\hline 31 & 2 & 16 & 1.72 \\
34 & 3 & 110 & 1.60 \\
35 & 5 & 42 & 1.47 \\
36 & 4 & 132 & 1.60 \\
\hline
\end{tabular}

The above velocities are considered typical for the depth and sediment type.

The difficulty in obtaining velocity measurements is attributed to: (1) the gassy state of the sediments, particularly in the unlithified section, and (2) the fracturing and fissuring of the more lithified portion of the sediment column.

\section{Shear Strength}

Figure 4 shows that shear strength increases gradually with depth. The scatter of values is expected inasmuch as the interval from Core $10(90 \mathrm{~m})$ to Core $29(275 \mathrm{me}$ ters) included highly gas-charged sediments.

Three zones are observed. Zone 1 (mud line to $90 \mathrm{~m}$ shows low shear strength (average $8.92 \mathrm{kPa}$ ) and little variation $(s=4.09)$. A gradual increase from $5.0 \mathrm{kPa}$ to $15 \mathrm{kPa}$ is observed. Zone $2(90-274 \mathrm{~m})$ shows an abrupt increase in shear strength (average $28.91 \mathrm{kPa}$ ) and considerable variation $(s=17.37)$. Zone $3(285-315 \mathrm{~m})$ resulted in a six-fold increase in shear strength (average $=323.2 \mathrm{kPa} ; s=45.81$ ) associated with a sharp increase in lithification. Below 315 meters, measurements were no longer possible.

Table 2 summarizes Site 497 physical properties.

\section{GEOPHYSICS}

We drilled at Site 497 to achieve some of the objectives not met at Site 496, which was abandoned for safety reasons. The principal target at Site 496, a landward dipping reflector at the top of a presumed slab of igneous rock, is not present at Site 497. However, an equivalent of the rock immediately overlying the igneous body appears to occur at Site 497 at a depth shallow enough to be readily drilled by the Glomar Challenger. Study of seismic records suggests that the Miocene and older units would be shallower at Site 497 than at Site 496 .

The seismic line made by the Challenger from Sites 496 to 497 shows a lower reflective sequence apparently continuous from one site to the other (Fig. 5; reflector [X]). The section above this sequence is much thinner at 497 than at 496 . The Miocene section drilled at 496 should have been penetrated within 240 meters at 497 , however, at Site 497, we bottomed at 397 meters still in Pliocene rock, 157 meters beyond the seismically determined Miocene boundary. ${ }^{3}$

\section{BIOSTRATIGRAPHY}

At Site 497, 200 meters (Cores 1-22) of biogenic and hemiterrigenous mud and 170 meters (lower part of Core

\footnotetext{
${ }^{3}$ Since this report was written, the record has been reprocessed; the dark boundary appears to be a reflection from the base of the gas hydrate zone at least to point $\mathrm{X}$.
}

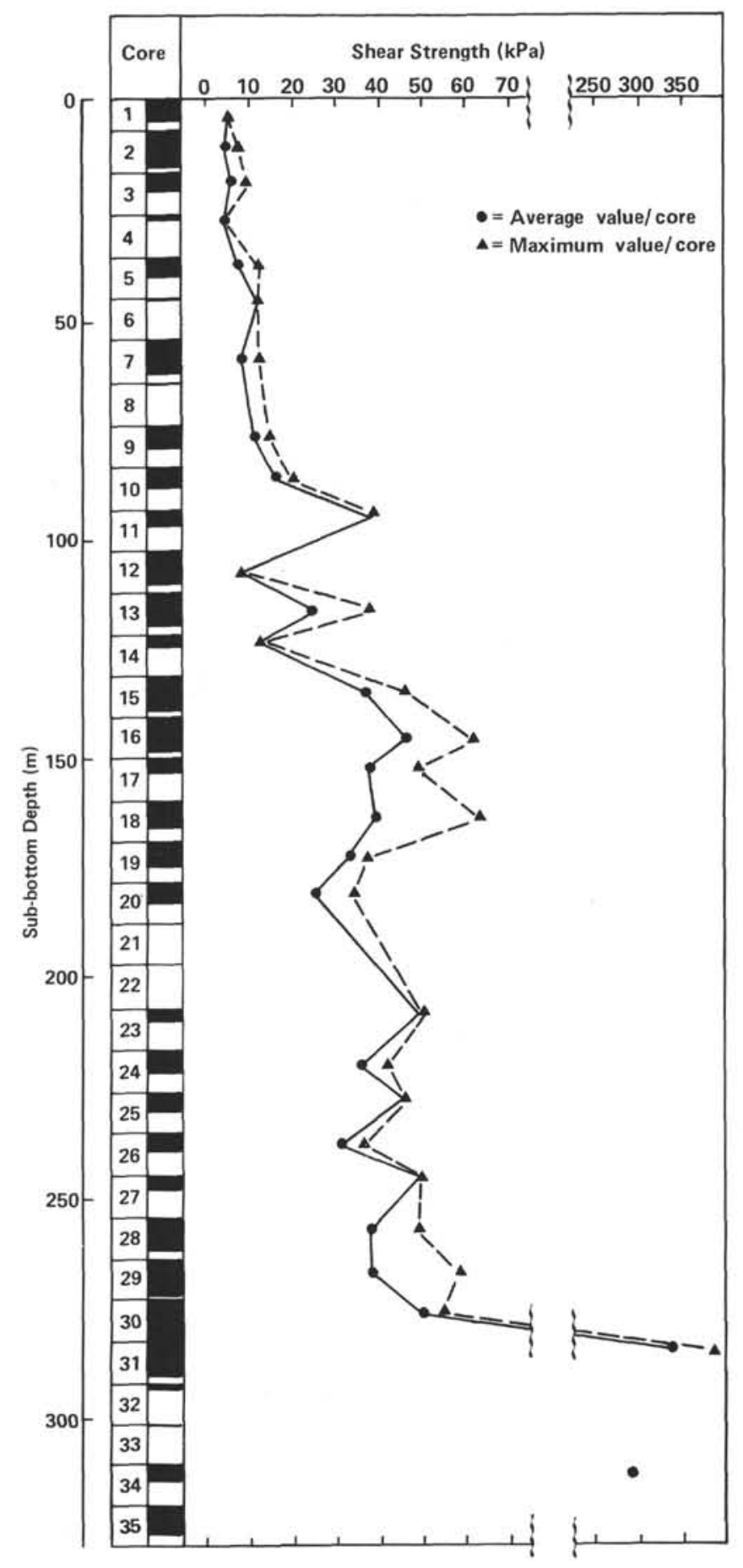

Figure 4. Shear strength of sediments at Site 497.

24-Core 42) of biogenic mudstone were cored, with about 15 meters of pebbly mudstone (Cores 23 and the top of Core 24) separating the upper from the lower unit. Both major sediment types are rich in microfossils, including diatoms, radiolarians, calcareous nannoplankton, and planktonic and benthic foraminifers; fecal pellets occur down to Core 19, and ostracodes were observed occasionally down to Core 10 .

Biostratigraphic markers delineating late Pleistocene through Pliocene (ca. 4.0 Ma) are common throughout the cores, and no unusual age discrepancies were ob- 
Table 2. Physical properties, Site 497.

\begin{tabular}{|c|c|c|c|c|c|c|}
\hline $\begin{array}{c}\text { Sample } \\
\text { (core-section, } \\
\text { interval }[\mathrm{cm}] \text { ) }\end{array}$ & $\begin{array}{l}\text { GRAPE } \\
\text { Wet-Bulk } \\
\text { Density } \\
\left(\mathrm{Mg} / \mathrm{m}^{3}\right)\end{array}$ & $\begin{array}{l}\text { P. Wave } \\
\text { Velocity } \\
(\mathrm{km} / \mathrm{s})\end{array}$ & $\begin{array}{c}\text { Acoustic } \\
\text { Impedance } \\
\left(\times 10^{5} \mathrm{~g} / \mathrm{cm}^{2} \cdot \mathrm{s}\right)\end{array}$ & $\begin{array}{l}\text { Shear } \\
\text { Strength } \\
(\mathrm{kPa})\end{array}$ & $\begin{array}{c}\text { Water } \\
\text { Content } \\
\text { (\%\% dry wt.) }\end{array}$ & $\begin{array}{l}\text { Porosity } \\
\text { (vol. \%) }\end{array}$ \\
\hline $1-1,98-102$ & 1.44 & - & - & 5.55 & 142.4 & 78.6 \\
\hline $1-4,48-50$ & - & - & - & 4.60 & - & - \\
\hline $2-1,138-140$ & - & - & - & 5.74 & 136.5 & 77.9 \\
\hline $2-4,115-118$ & 1.43 & - & - & 5.74 & - & - \\
\hline $2-6,112-114$ & - & - & - & 6.32 & 111.5 & 74.3 \\
\hline $3-3,60-64$ & 1.42 & - & - & 6.13 & - & - \\
\hline $3-3,80-82$ & 1.43 & - & - & 6.70 & 116.9 & 75.2 \\
\hline $4-1,110-112$ & - & - & - & 5.27 & 113.0 & 74.5 \\
\hline $5-1,80-84$ & 1.46 & - & - & 11.11 & - & - \\
\hline $5-3,80-84$ & - & - & - & 7.28 & 100.3 & 72.2 \\
\hline $6 \cdot 1,45-47$ & - & - & - & 12.64 & 107.3 & 73.1 \\
\hline $7-1,130-132$ & - & - & - & 6.13 & - & - \\
\hline $7-4,100-102$ & 1.50 & - & - & 12.26 & 85.1 & 73.6 \\
\hline $9-2,14-16$ & 1.50 & - & - & 13.41 & - & - \\
\hline $9-3,20-22$ & - & - & - & 9.19 & 96.8 & 71.5 \\
\hline $10-2,60-62$ & 1.48 & - & - & 13.41 & - & - \\
\hline $10-4,30-32$ & 1.50 & - & - & 18.77 & 96.5 & 71.5 \\
\hline $11-1,142-144$ & - & - & - & 38.30 & - & - \\
\hline $12-6,76-78$ & - & - & - & 35.91 & 103.5 & 72.9 \\
\hline $13-4,92-94$ & 1.43 & - & - & 20.10 & 84.7 & 68.6 \\
\hline $13-7,118-120$ & - & - & - & 36.39 & 105.0 & 73.2 \\
\hline $14-3,63-65$ & 1.48 & - & - & 12.06 & 95.7 & 71.3 \\
\hline $15-1,134-136$ & 1.45 & - & - & 41.17 & - & - \\
\hline $15-2,133-135$ & 1.45 & - & - & 44.05 & 88.8 & 69.8 \\
\hline $15-5,131-133$ & 1.55 & - & - & 28.73 & - & - \\
\hline $15-6,140-142$ & - & - & - & 44.05 & 83.8 & 68.4 \\
\hline $16-2,129-131$ & 1.56 & - & - & 61.29 & 80.0 & 67.4 \\
\hline $16-4,89-91$ & 1.55 & - & - & 33.52 & - & - \\
\hline $16-6,78-80$ & 1.54 & - & - & 54.58 & - & - \\
\hline $16-8,30-32$ & - & - & - & 33.52 & 96.3 & 71.4 \\
\hline $17-1,140-142$ & - & - & - & 38.30 & - & - \\
\hline $17-2,50-52$ & 1.55 & - & - & 47.88 & - & - \\
\hline $17-3,50-52$ & - & - & - & 28.73 & 92.4 & 70.5 \\
\hline $18-1,99-101$ & 1.50 & - & - & 19.15 & - & - \\
\hline $18-3,68-70$ & - & - & - & 62.24 & 80.0 & 66.7 \\
\hline $18-6,40-42$ & - & - & - & 33.52 & - & - \\
\hline $19-2,123-125$ & 1.50 & - & - & 32.56 & - & - \\
\hline $19-4,113-115$ & 1.55 & - & - & 36.39 & 79.6 & 67.3 \\
\hline $20-3,12-14$ & - & - & - & 33.52 & 126.4 & 76.7 \\
\hline $20-5,90-92$ & 1.47 & - & - & 19.15 & - & - \\
\hline $23-3,10-14$ & - & - & - & 49.79 & 90.6 & 70.2 \\
\hline $24-2,70-72$ & 1.55 & - & - & 39.26 & - & - \\
\hline $24-4,50-54$ & 1.56 & - & - & 33.52 & - & - \\
\hline $25-1,90-92$ & 1.51 & - & - & 44.05 & - & - \\
\hline $25-4,32-34$ & - & - & - & 45.96 & - & - \\
\hline $26-1,100-102$ & - & - & - & 33.52 & - & - \\
\hline $26-3,100-102$ & 1.53 & - & - & 28.73 & - & - \\
\hline $27-1,80-82$ & 1.57 & - & - & 49.79 & 72.0 & 65.1 \\
\hline $27-2,130-132$ & 1.55 & - & - & 47.88 & - & - \\
\hline $28-1,130-132$ & 1.50 & - & - & 47.88 & - & - \\
\hline $28-3,130-132$ & 1.52 & - & - & 23.94 & 78.5 & 66.4 \\
\hline $28-5,30-32$ & 1.54 & - & - & 38.30 & - & - \\
\hline $29-2,70-72$ & - & - & - & 57.46 & - & - \\
\hline $29-4,95-97$ & - & - & - & 28.73 & - & - \\
\hline $29-6,68-70$ & 1.58 & - & - & 26.81 & - & - \\
\hline $30-2,80-82$ & - & - & - & 53.62 & - & - \\
\hline $30-4,83-85$ & - & - & - & 51.71 & 84.0 & 67.8 \\
\hline $30-6,123-125$ & 1.60 & - & - & 44.05 & - & - \\
\hline $31-2,98-100$ & - & - & - & 383.04 & - & - \\
\hline $31-4,26-28$ & - & - & - & 335.16 & - & - \\
\hline $31-8,26-28$ & - & - & - & 287.28 & - & - \\
\hline $34-2,129-131$ & - & - & - & 287.28 & - & - \\
\hline
\end{tabular}

served (Fig. 6). The Pliocene/Pleistocene boundary is placed at Core 17 , Section $3,22-30 \mathrm{~cm}$ on the basis of nannofossil evidence.

Radiolarian assemblages below Core 18 through Core 42 all belong to the Pliocene Spongaster pentas Zone. Foraminiferal faunas contain species that range across the Miocene/Pliocene boundary, however, index species of the uppermost Miocene such as Globorotalia plesiotumida are not present. Nannofossils, on the other hand, indicate that the Miocene/Pliocene boundary lies between Cores 36 and 37.

The shape of the sedimentation rate curve is similar to that seen at Site 496-both have very high rates during the Quaternary and both show an inflection at about 220 meters; Site 496 shows a slower rate below this depth for the Pliocene, whereas Site 497 continues at the Quaternary rate (Fig. 7). The accumulation curves vary greatly at sites just 4 miles apart.

\section{Foraminifers}

The foraminifers at Site 497 resemble those seen at 496 , which is not unexpected considering the proximity of the two sites. The planktonic assemblage is composed of abundant Neogloboquadrina ( $N$. eggeri in the Quaternary; its ancestral form $N$. humerosa in the Pliocene) along with common Globerinoides ruber, G. sacculifer, and Orbulina. The benthic foraminiferal fauna includes the lower bathyal (1600-3000 m) taxa Hoeglundina elegans, Globobulimina, Bulimina barbata, B. pagoda, Uvigerina peregrina, U. senticosa, U. hispida, Pyrgo, Sphaeroidina bulloides, Pullenia bulloides, Nodosaria, Stilostomella, Martinottiella, Eggerella, and Melonis. The sequence of benthic assemblages suggests a gradual increase in water depth from the Pliocene to the present day (Fig. 8).

Several planktonic species provide useful biostratigraphic markers. The disappearance of pink-pigmented Globerinoides ruber in Core 3, Section 3 indicates an approximate age of 125,000 yr. for this level. Neogloboquadrina humerosa disappears between Core 11, Section 1 and Core 12, Section 3, a level dated at about 1.1 Ma. Globigerinoides fistulosus becomes extinct in Core 18 , whereas $N$. eggeri appears also in Core 18 , the overlap serving to locate the Pliocene/Pleistocene boundary. The Pliocene extinction of Globoquadrina altispira provides an average date of $2.8 \mathrm{Ma}$. Rare occurrences of Globoquadrina venezuelana, Globigerina nepenthes, and Pulleniatina praepulleniatina in Cores 39 to 41 indicate proximity to the Miocene/Pliocene boundary.

\section{Radiolarians}

Radiolarian assemblages at Site 497 are moderately well preserved but for the most part very diluted with terrigenous sediment. The species present and their abundances change very little throughout the sequence.

The last occurrence of Axoprunum angelinum, which indicates an age of 400,000 years, was noted between Cores 7 and 9 . Although there are some very rare occurrences of Anthocyrtidium angulare (an indicator of the oldest Quaternary zone) in Cores 15, 16 and 18, the Pliocene/Pleistocene boundary cannot be placed with confidence because the marker species, Pterocanium prismatium, does not occur at this site.

The top of the Spongaster pentas Zone, which is marked by the last occurrence of Stichocorys peregrina, is between Cores 25 and 26 . The evolutionary transition between Didymocyrtis penultima and D. avita between Samples $497-36-8,35-37 \mathrm{~cm}$ and $497-35-2,41-43 \mathrm{~cm}$ is an event that also belongs to the Pliocene $S$. pentas Zone. In contrast to the nannofossil evidence that deposition of Cores 38 to 42 took place in the late Miocene, the sparse radiolarian assemblages of Cores 38 and 39 and the more abundant ones of 41 and 42 all belong to the Pliocene $S$. pentas Zone.

\section{Nannoplankton}

A sequence of Quaternary through upper Miocene deposits was recovered from cores at Site 497. Nannoplankton are well preserved and range in abundance from few to common. 


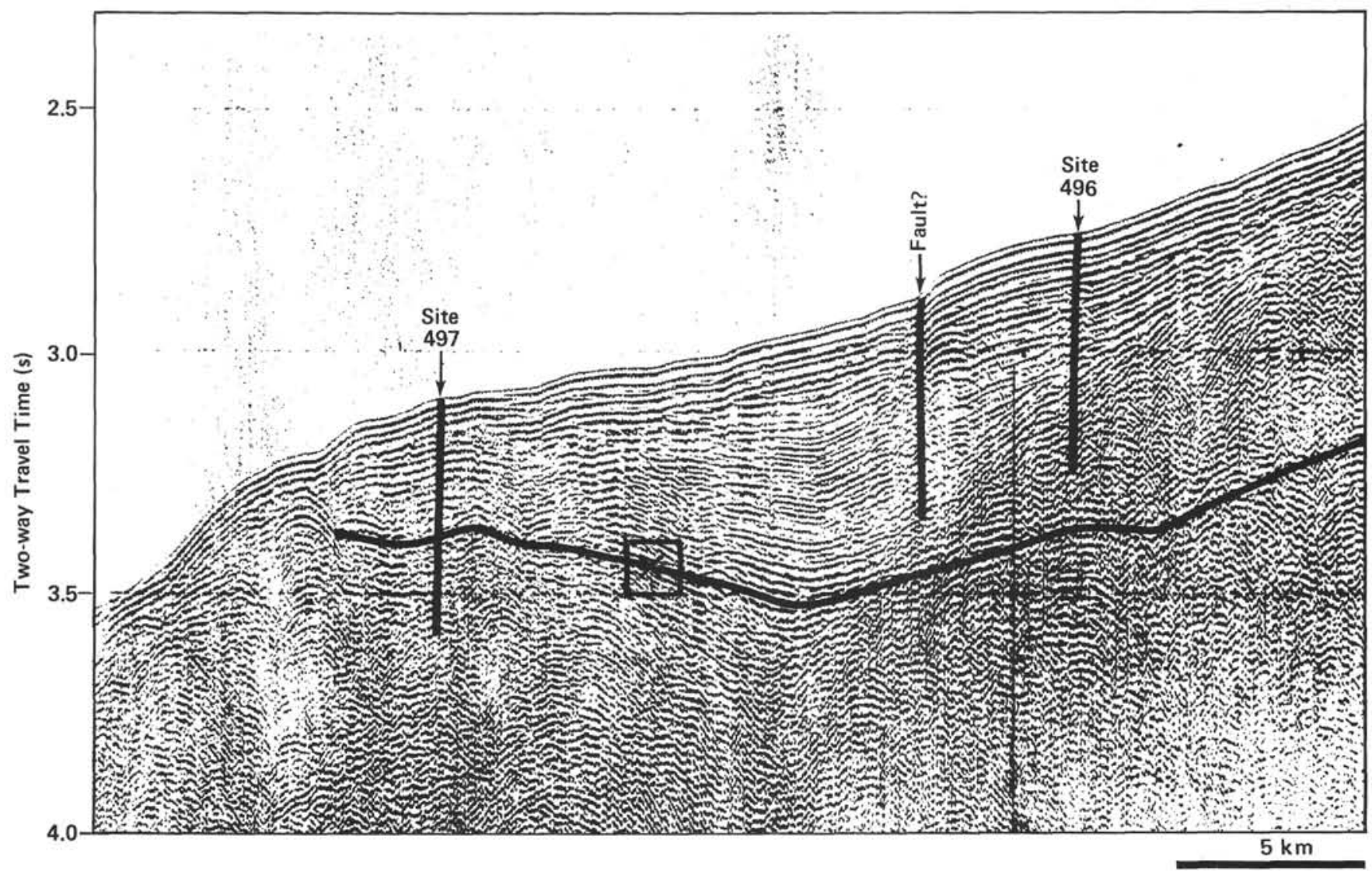

Figure 5. Seismic reflection profile across Site 497.

\begin{tabular}{|c|l|l|l|}
\hline Series & \multicolumn{1}{|c|}{$\begin{array}{c}\text { Sample } \\
\text { (hole-core) }\end{array}$} & $\begin{array}{c}\text { Approximate } \\
\text { Sub-bottom } \\
\text { Depth of } \\
\text { Boundary(m) }\end{array}$ & Basis for Boundary Position \\
\hline Quaternary & $497-1 \rightarrow 17$ & Top of D. brouweri Zone \\
\hline upper Pliocene & $497-18 \rightarrow 30$ & $\begin{array}{l}\text { Top of Sphaeroidinellopsis } \\
\text { Top of } R \text {. pseudoumbilica Zones }\end{array}$ \\
\hline lower Pliocene & $497-31 \rightarrow 37$ & $\begin{array}{l}\text { Radiolarians: Spongaster pentas } \\
\text { Zone to } 497-42\end{array}$ \\
\hline lower Pliocene/ \\
upper Miocene
\end{tabular}

Figure 6. Stratigraphic series at Site 497.

Core 1 to Core 17, Section 3, 30-32 cm, contain Pleistocene nannoplankton. In Core 18 to Sample 497-23,CC very rare specimens of Discoaster brouweri were found together with Gephyrocapsa sp. and other undetermined small coccoliths. This interval may belong to the Pliocene.
Typical upper Pliocene assemblages of the Discoaster brouweri Zone are contained in Sections 497-24-4 to 497-32-1: D. brouweri, D. pentaradiatus, D. asymmetricus, and D. decorus.

Ceratoliths are practically absent in the hole. Nevertheless the occurrence of Ceratolithus acutus in Sample 


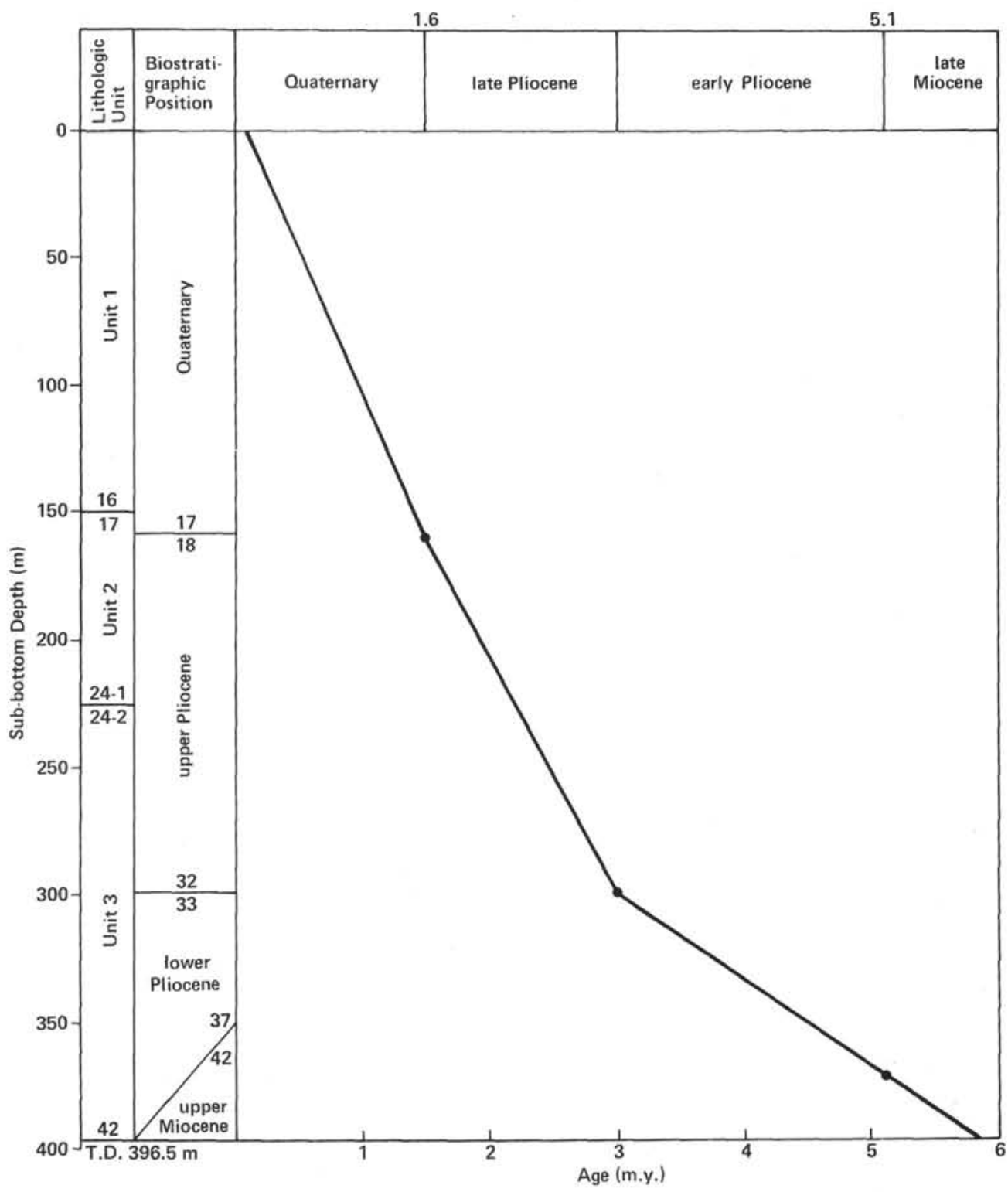

Figure 7. Sedimentation rate at Site 497. (Numbers shown at the boundary lines in the Lithologic Unit and Biostratigraphic Position columns indicate cores and sections of Hole 497.)

497-36-6, 46-48 cm determines its age and the age of underlying samples as not younger than the Ceratolithus acutus Subzone. Amaurolithus amplificus, found in Sample 497-42-2, 25-27 cm, occurs from the Triquetrorhabdulus rugosus Subzone of the Amaurolithus tricorniculatus Zone to the Ceratolithus primus Subzone of the Discoaster quinqueramus Zone. As the zonal form of the last zone was not recorded in the site section, it is most likely that the hole ends in the Amaurolithus tricorniculatus Zone (lower Pliocene to upper Miocene).

\section{GEOCHEMISTRY}

\section{Organic Geochemistry}

Site 497 is situated only about 4 miles from Site 496 and thus was subject to the same hydrocarbon monitoring program. Gas chromatographs, the Imco fluoro- scope, and the Rock-Eval were used as described for Site 496.

Figure 9 shows the progressive decrease in the methane/ethane ratios with depth. Drilling was terminated at about 400 meters because of excessive pressure in the core barrel and because clathrates were being cored and recovered. Several lines of evidence document the presence of clathrates. Temperature data obtained from wireline tools indicate a bottom-hole temperature of about $8^{\circ} \mathrm{C}$; estimates of pressure conditions suggest that pressures are in the 250 to 275 atmosphere range. These $P-T$ (pressure-temperature) conditions are well within the stability field of methane-ethane- $\mathrm{CO}_{2}$ clathrates. The pressure of expanding gas ejected pieces of the ice interbedded with sediment from the core barrel. Finally, pieces of recovered clathrate, allowed to come to ambient temperature in a pressure vessel fitted with a gauge, gen- 


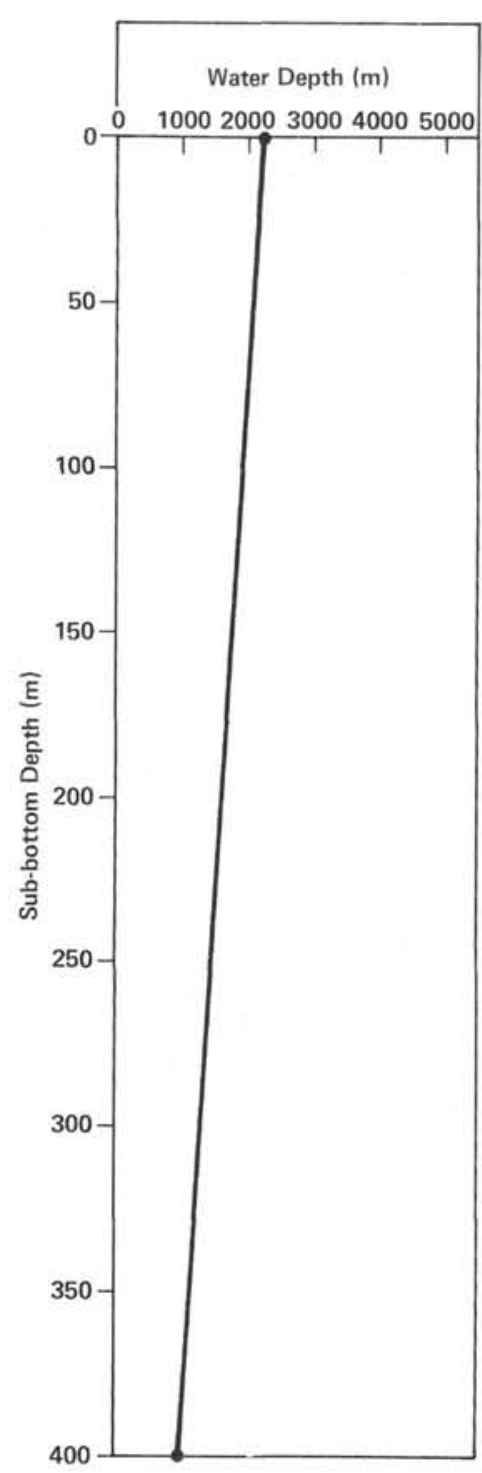

Figure 8. Paleobathymetry at Site 497 based on benthic foraminifers.

erated pressures of 18 to $19 \mathrm{psi}$. These pressures were generated from approximately $4 \mathrm{~cm}^{3}$ of ice and from a mixture of methane with minor amounts of ethane (the minimum $C_{1} / C_{2}$ ratio was 2365). Figure 10 indicates that the estimated and measured $P-T$ conditions in effect at Site 497 are well within the stability field for clathrates.

In Figure 11, methane is shown in volume percent of gas sampled and ethane in ppm. As at previous sites, methane concentrations are fairly uniform over the entire section penetrated, averaging about $78 \%$. Ethane concentrations are less than $50 \mathrm{ppm}$ from 0 to $210 \mathrm{me}$ ters sub-bottom depth (with a single exception of 99 ppm at $166.6 \mathrm{~m}$ ). From 210 meters to T.D. (total depth), ethane concentrations get progressively greater with depth. Higher ethane values in the interval between 360 and 395 meters affected the methane/ethane ratios so that four out of the last five determinations had ratios in the 2300 to 4300 range.

Figure 12 shows the distribution of neopentane and isobutane. Concentrations of isobutane are greater than

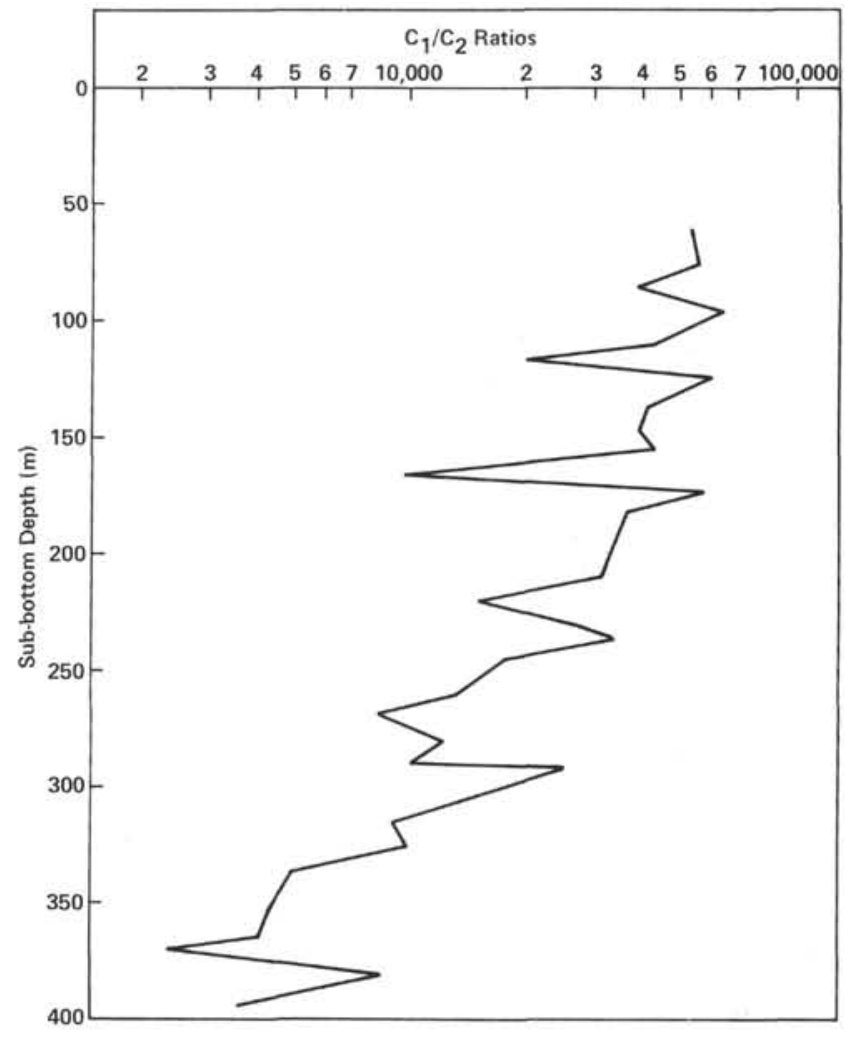

Figure 9. Methane/ethane ratios at Site 497.

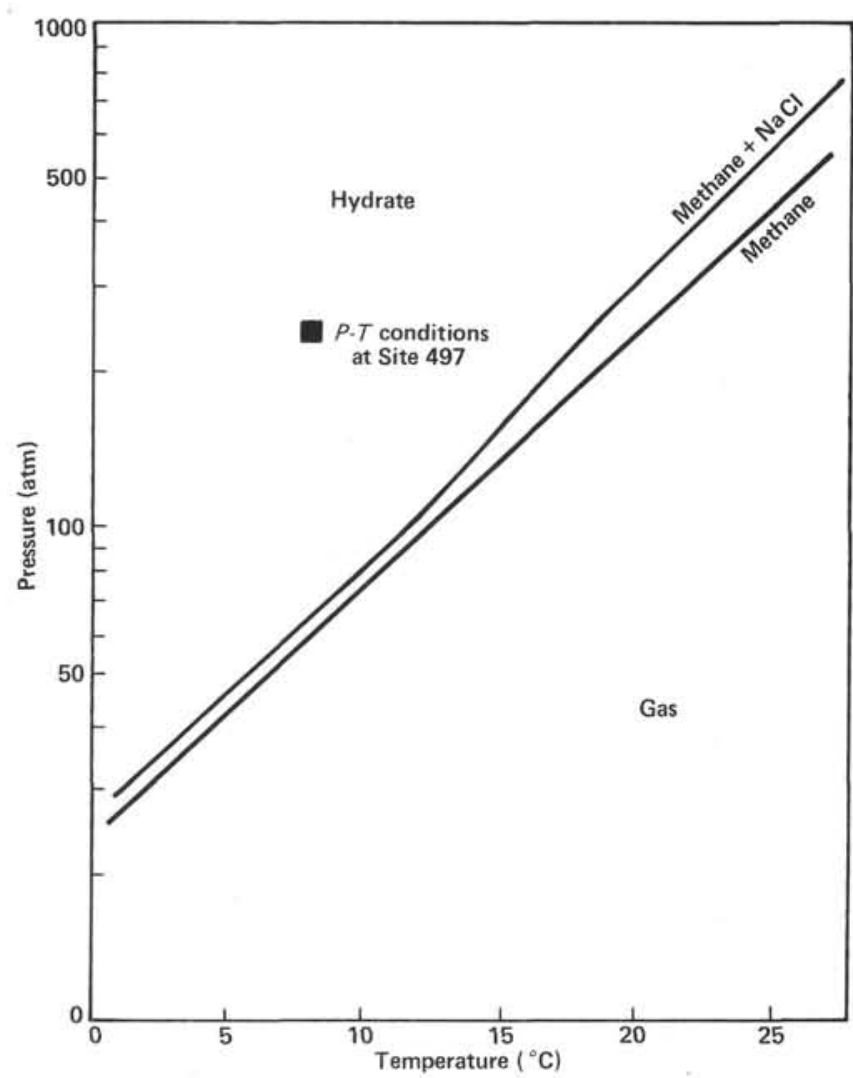

Figure 10. Pressure-temperature $(P-T)$ stability field of hydrates and $P-T$ conditions at Site 497. 


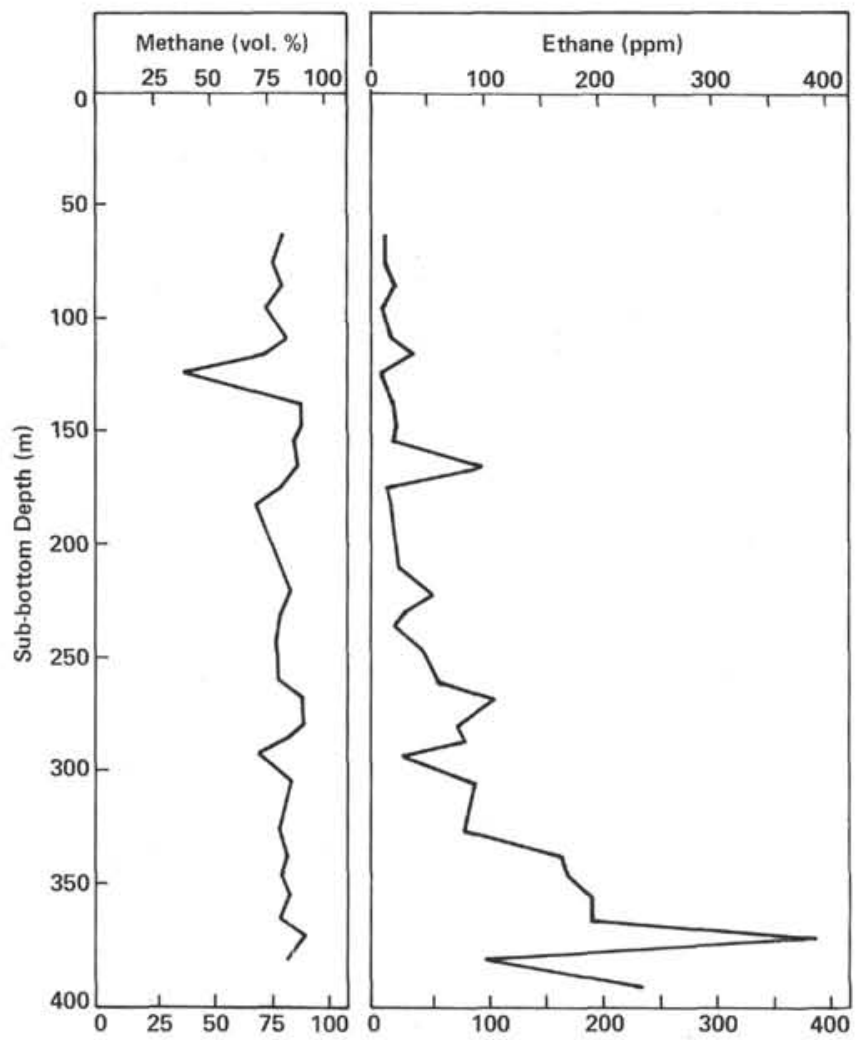

Figure 11. Methane and ethane concentrations at Site 497.

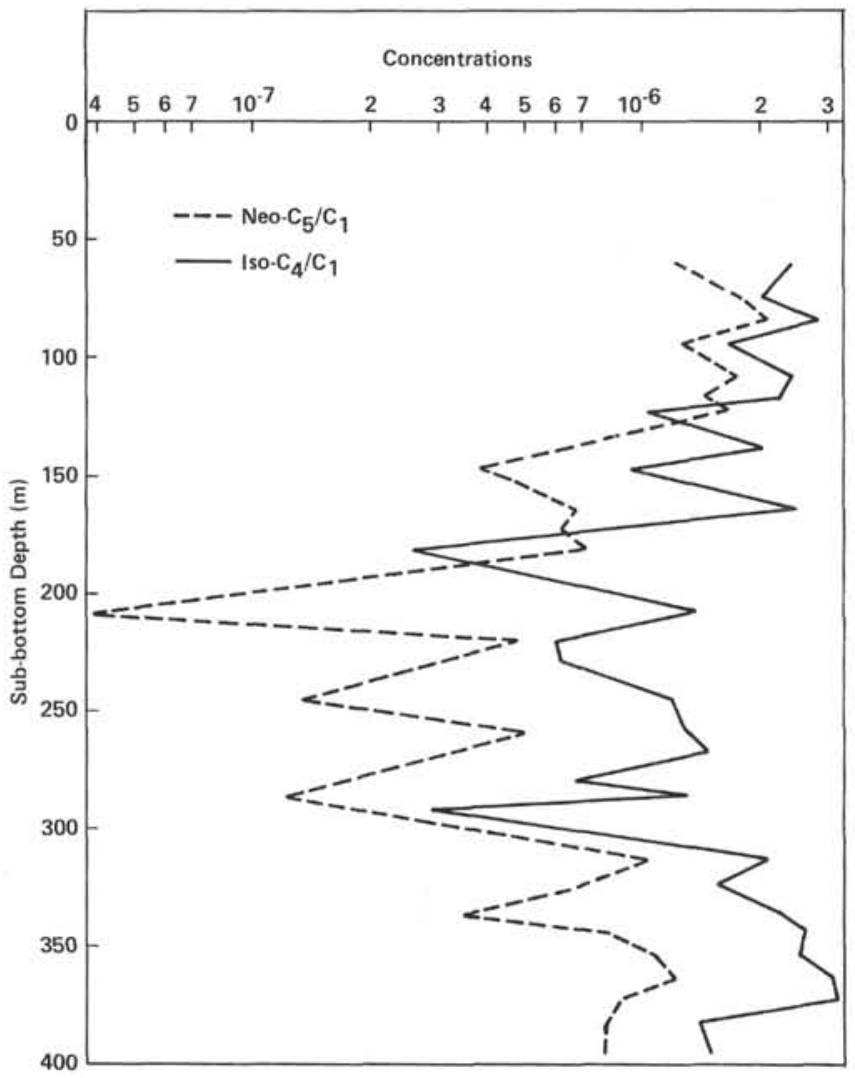

Figure 12. Neopentane and isobutane concentrations at Site 497. those of neopentane in 30 of the 32 samples analyzed. The possible diagenetic relation proposed on the basis of Site 494 data does not appear to be supported by data obtained at other sites.

Results from the shipboard interstitial water program are presented in Figure 13. The data are remarkably similar to that obtained at Site 496. Salinity, chlorinity, and magnesium values all show a regular decrease with increasing depth. The $p \mathrm{H}$ measurements are relatively constant and are in the 7.5 to 8.0 range throughout the entire section penetrated. As at Site 496, alkalinity values increase in the upper part of the penetrated section and then decrease in the lower portion. Calcium values also show the same pattern as that obtained at Site 496. Calcium content decreases in the first two samples and then remains constant to total depth.

\section{SUMMARY AND CONCLUSIONS}

The primary objective of drilling at Site 497 was to sample a landward-dipping reflective horizon that may represent an imbricate slice. However, the site was abandoned about 500 meters short of the primary objective because of gas hydrate. The dominant lithology is olive gray mud, with varying minor biogenic and vitric tuffaceous constituents. A short interval of rapidly deposited sandy mud and pebbly mudstone occurs at 206 to 218 meters. Near-vertical, dark colored veinlets, probably associated with dewatering and synsedimentary tectonism, occur in the lower, more lithified part of the section.

Quaternary and Pliocene microfossils are generally abundant in the section, and there are no unusual age discrepancies. Age increases linearly with depth except in an interval of pebbly mudstone where the rate of deposition was high, and immediately beneath it, where for an interval the rates of deposition were exceptionally low.

Physical properties measurements show a clear difference between the upper soft mud and the lower semilithified mudstone. The effects of gas and perhaps gas hydrates are evident in the small change of void ratio with depth.

Seismic records between Sites 496 and 497 indicate a thinning of the Neogene section toward 497. Drilling shows that the Pleistocene is thinner and the Pliocene much thicker at 497 than at 496 . The unconformity suggested in seismic record GUA-13 may help explain the discrepancy between the seismic interpretation and drilling results. 


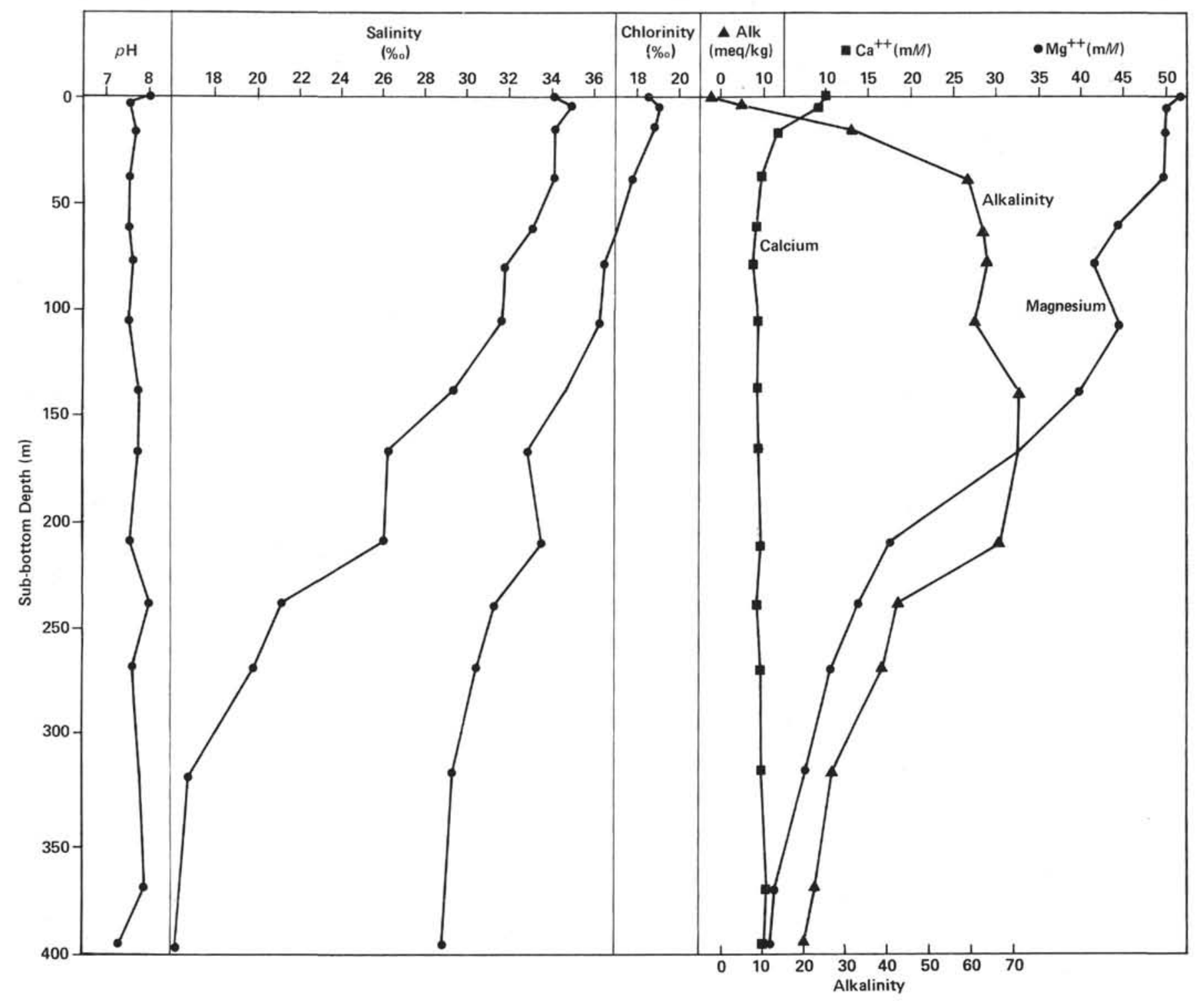

Figure 13. Interstitial water data at Site 497. 

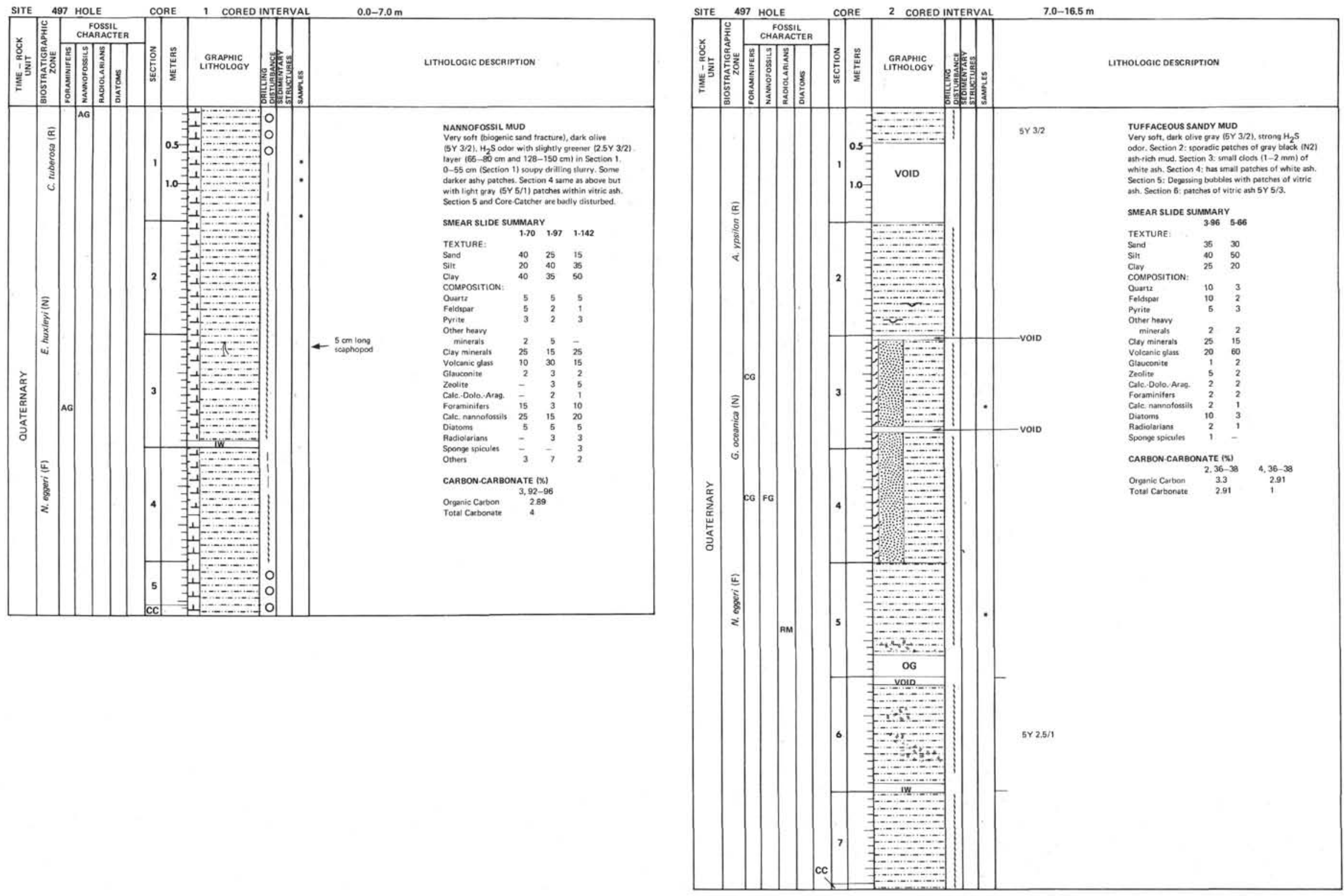


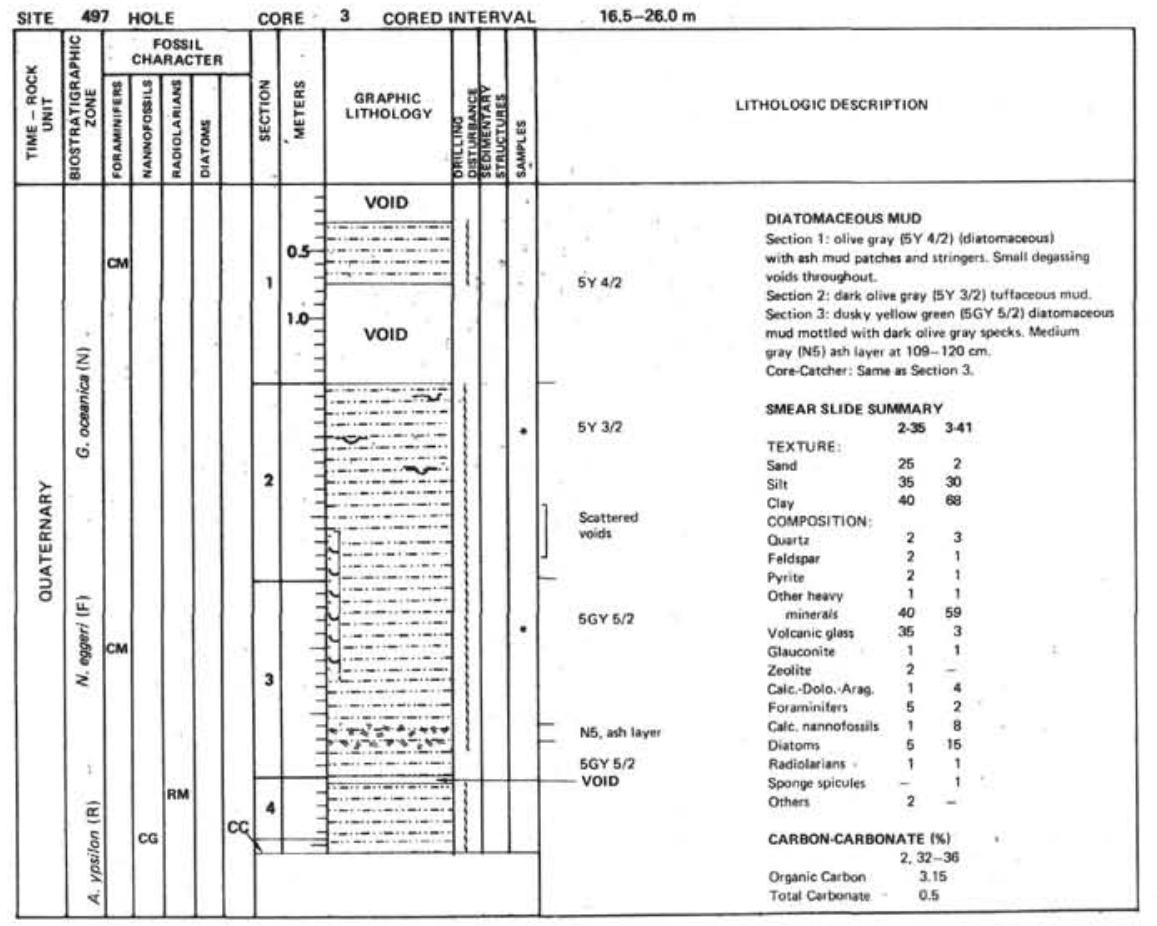

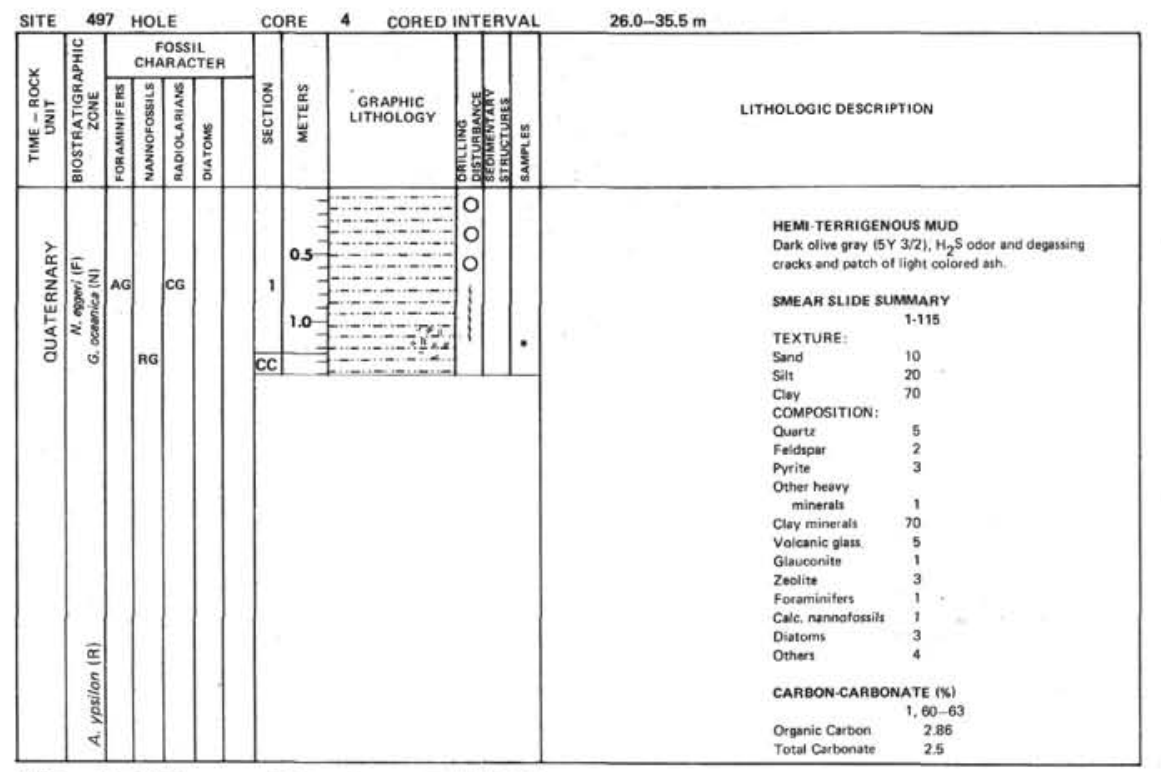

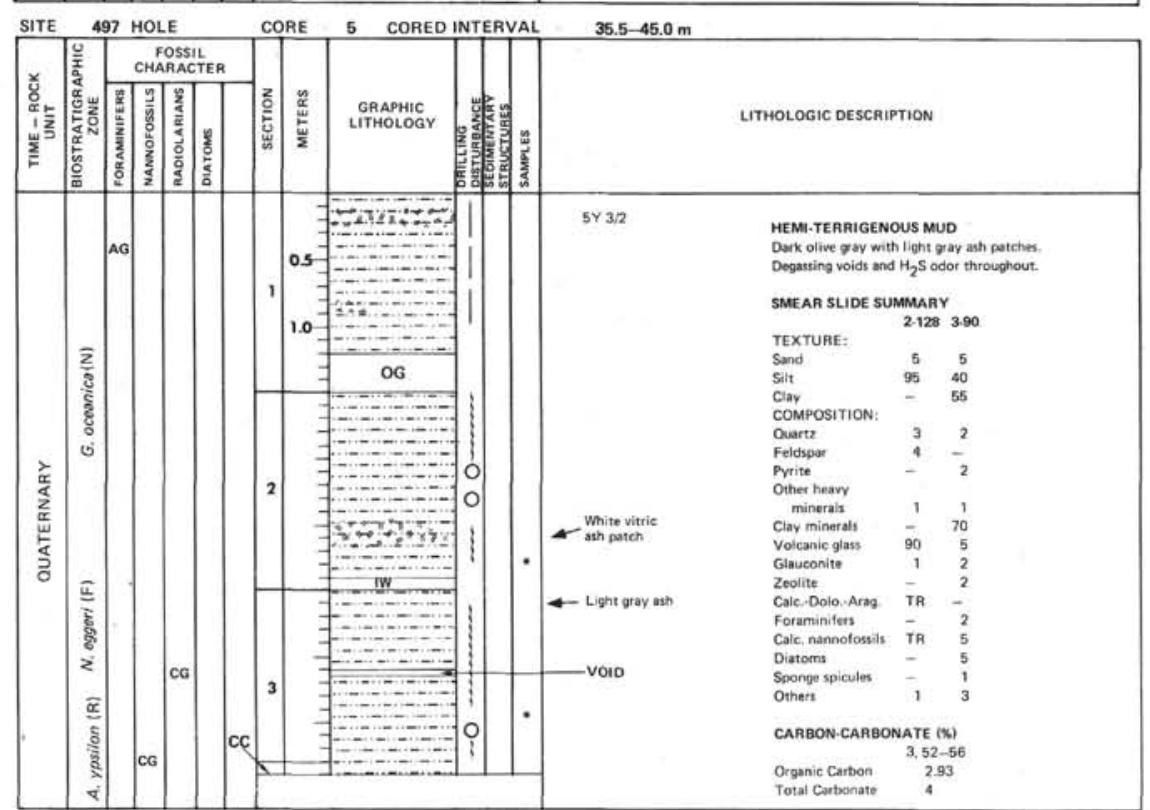



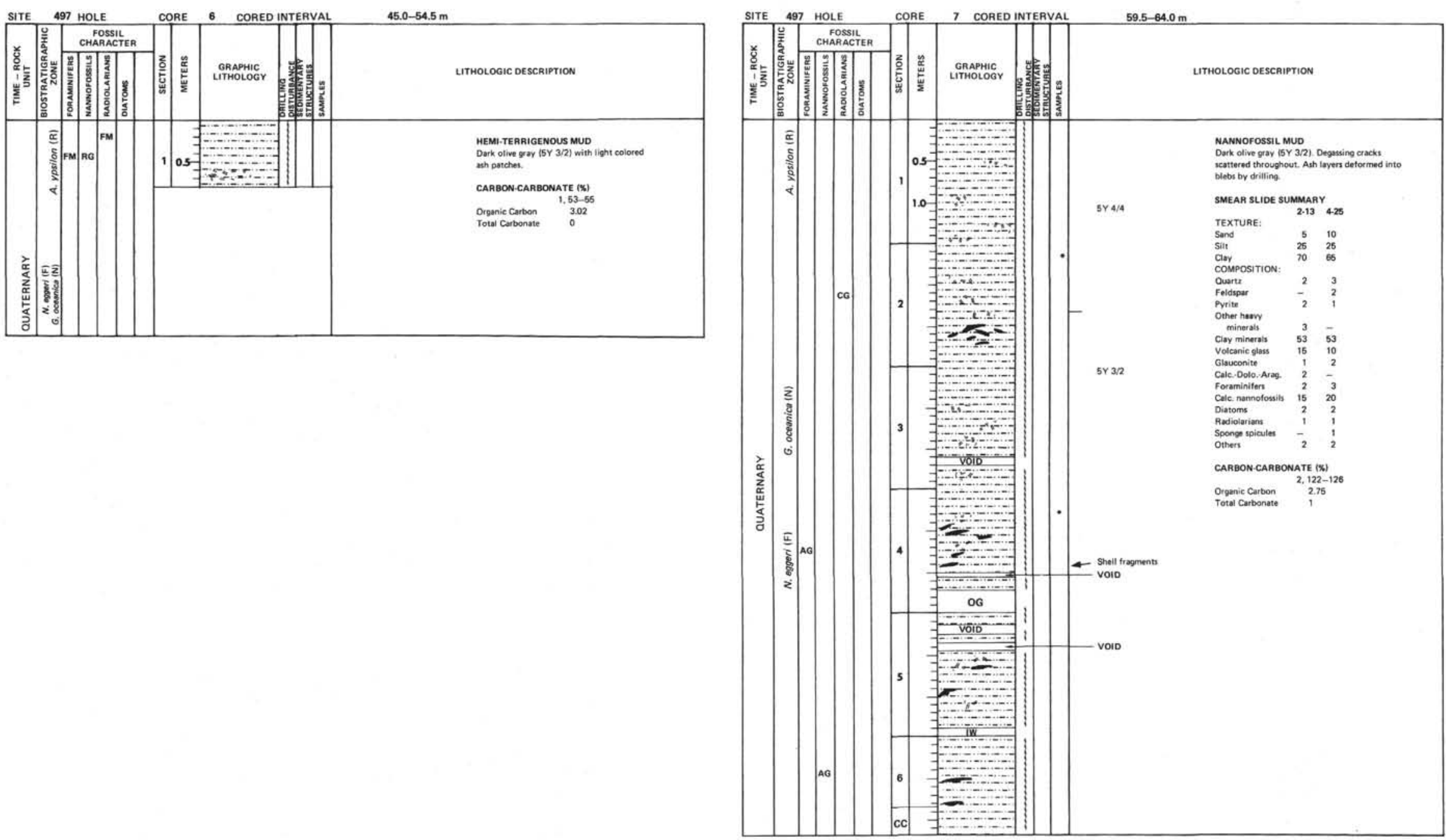

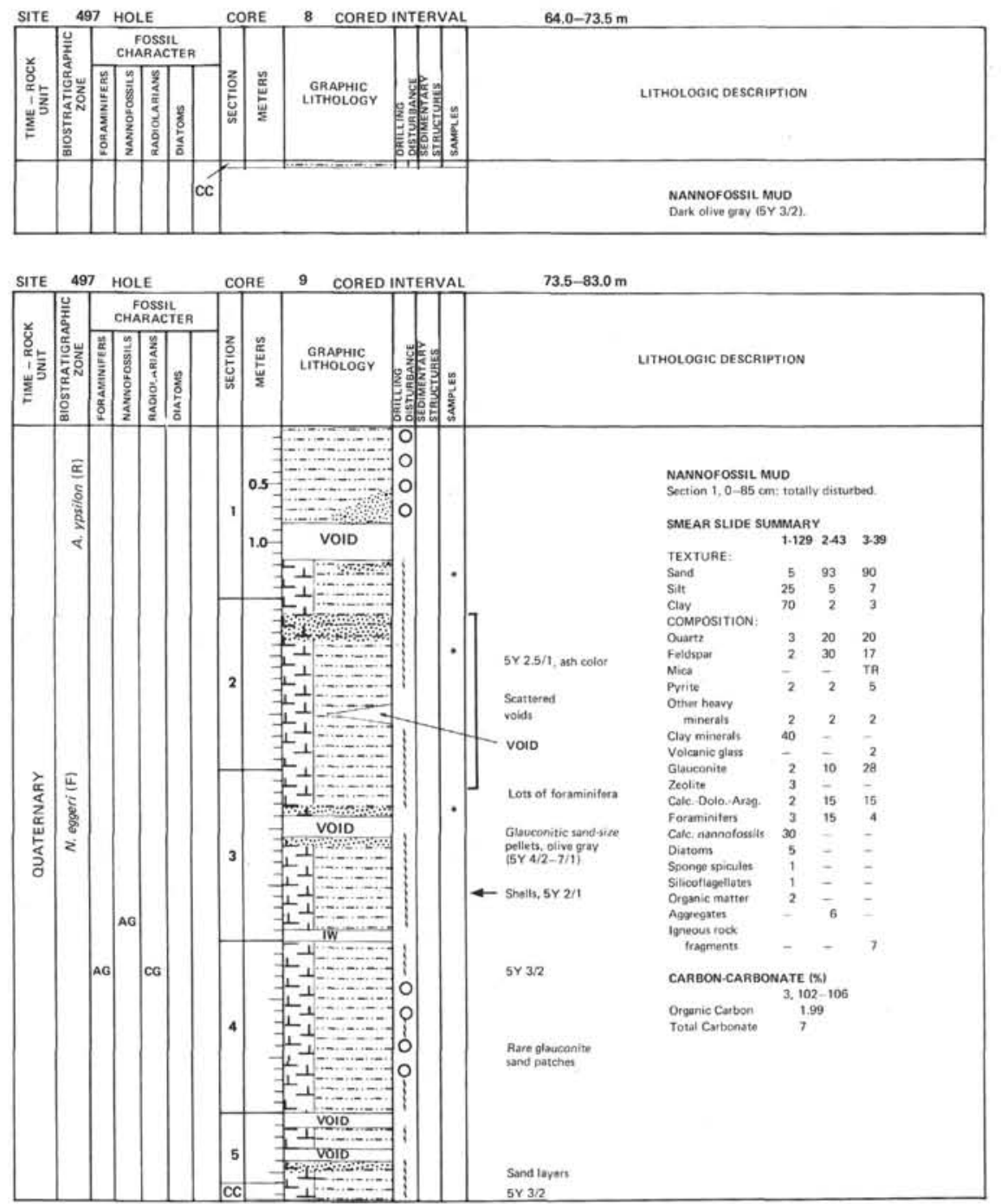

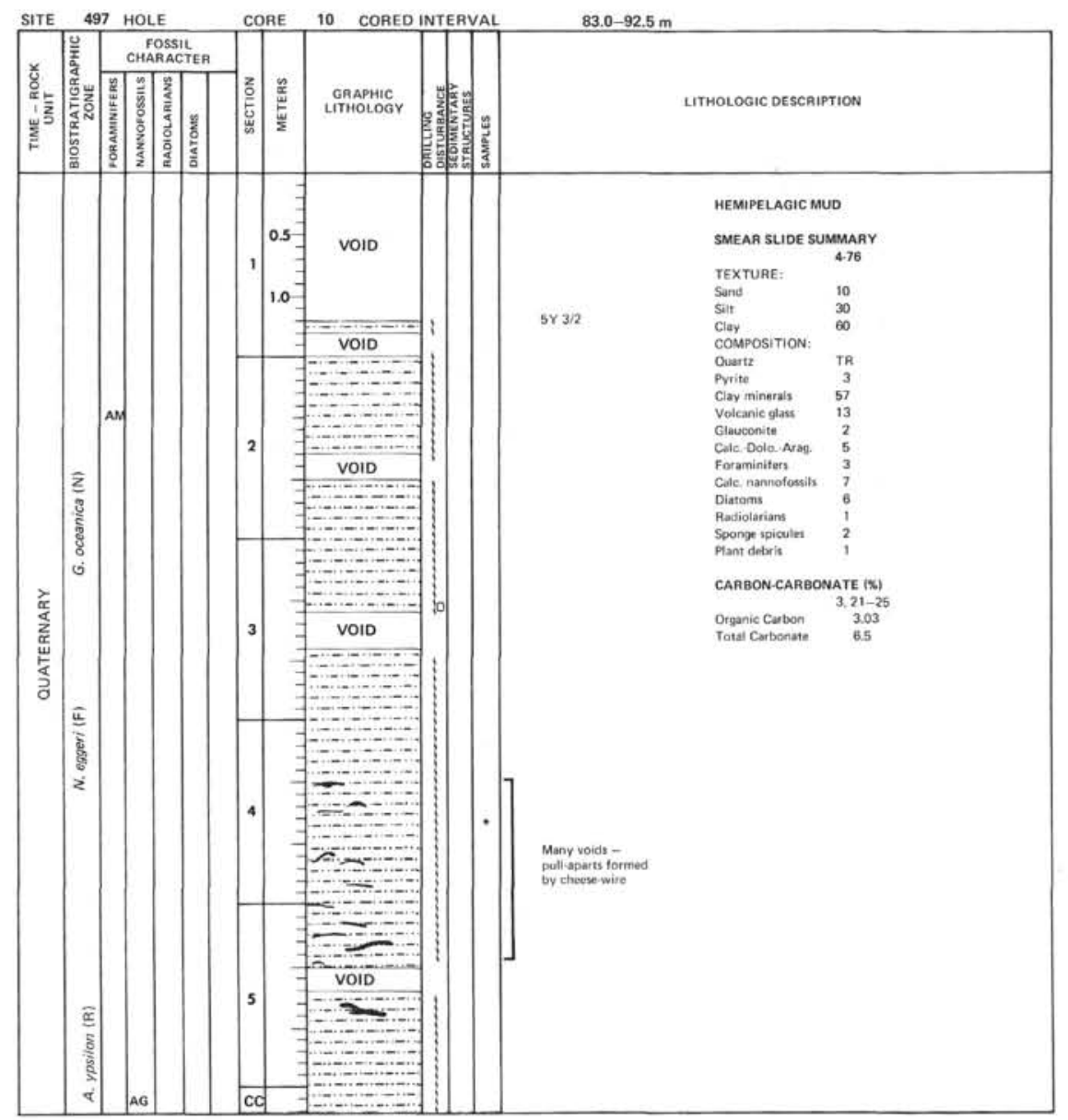



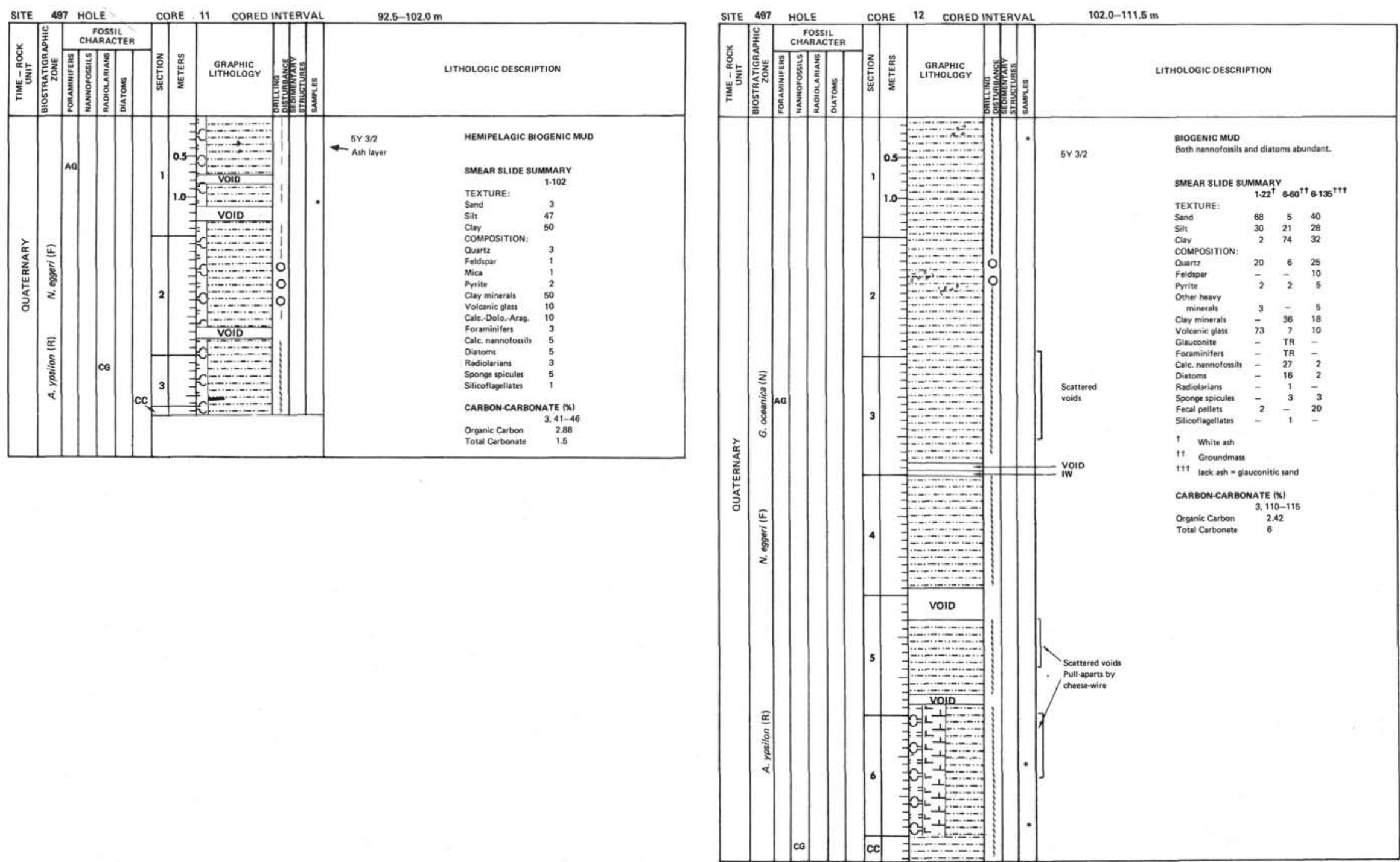


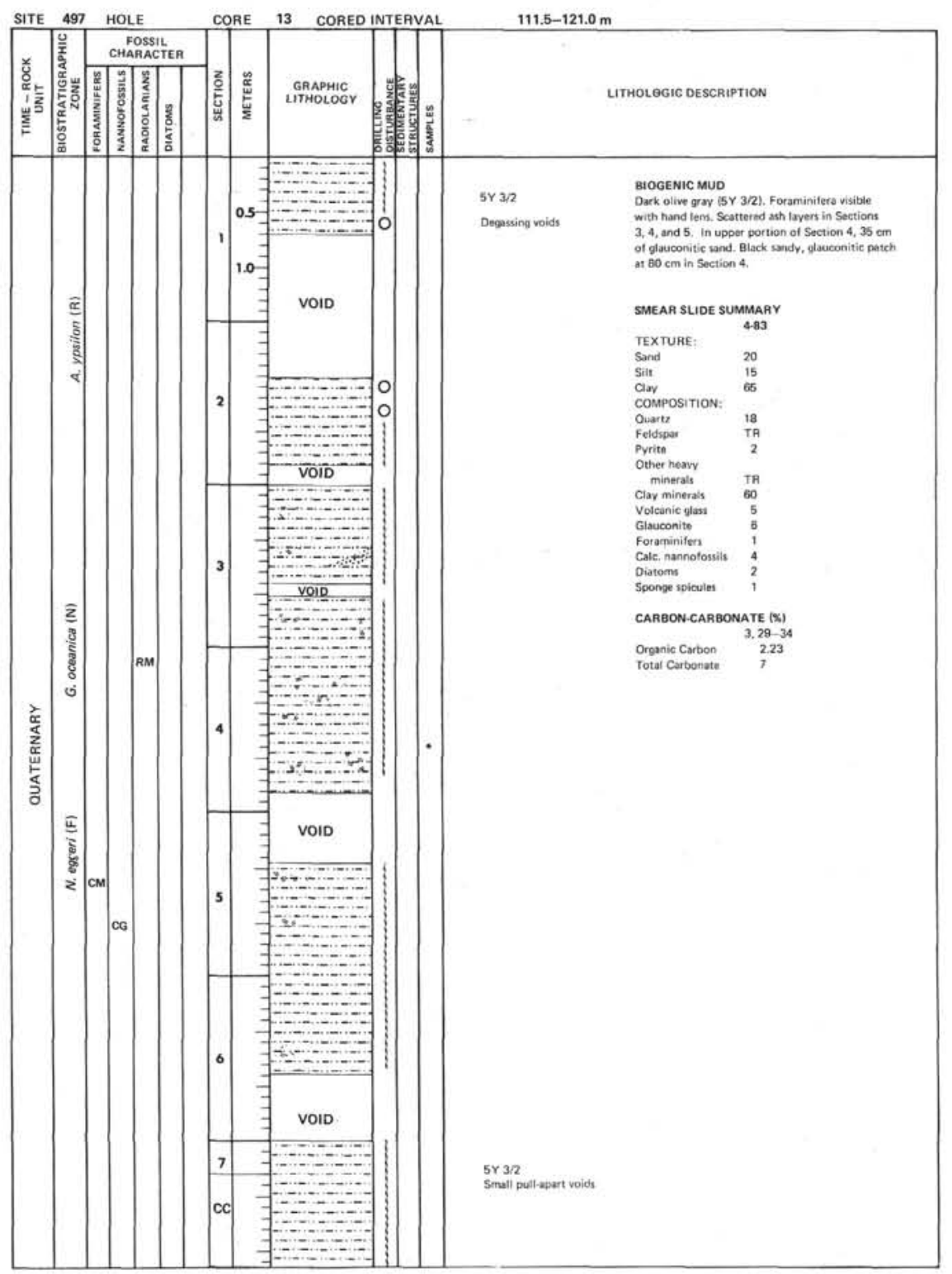

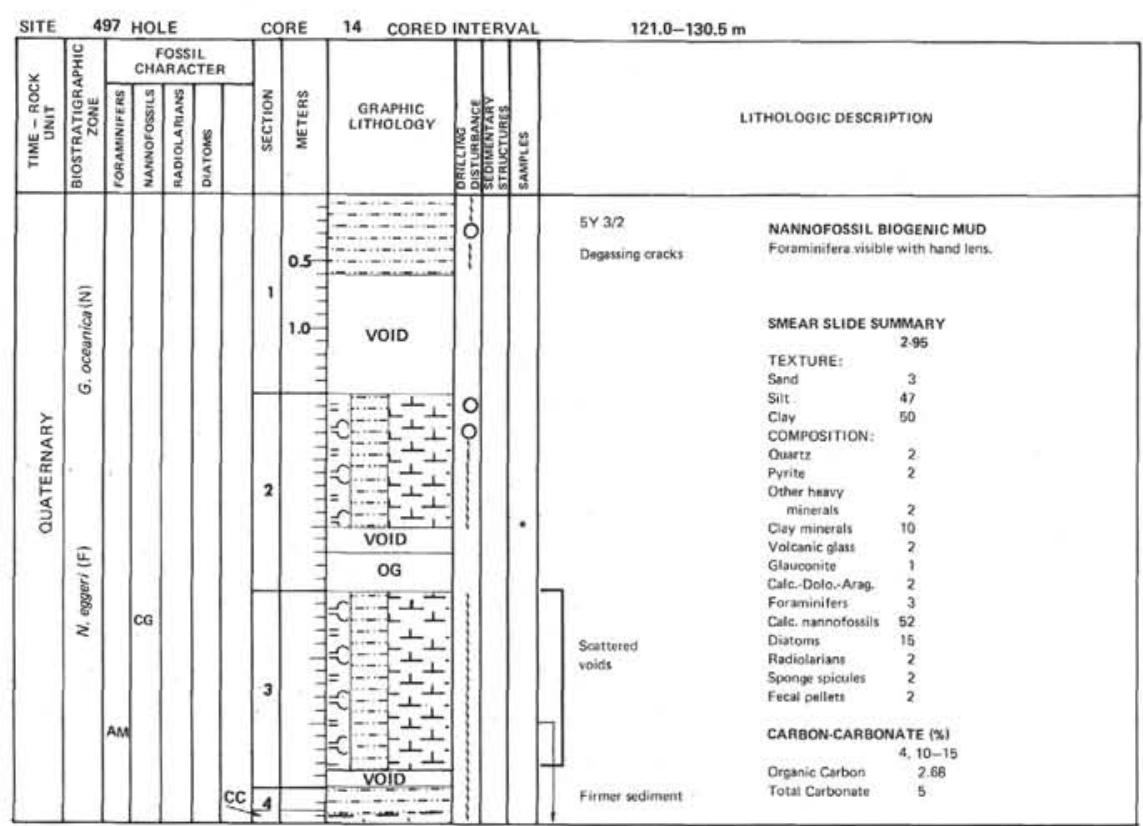



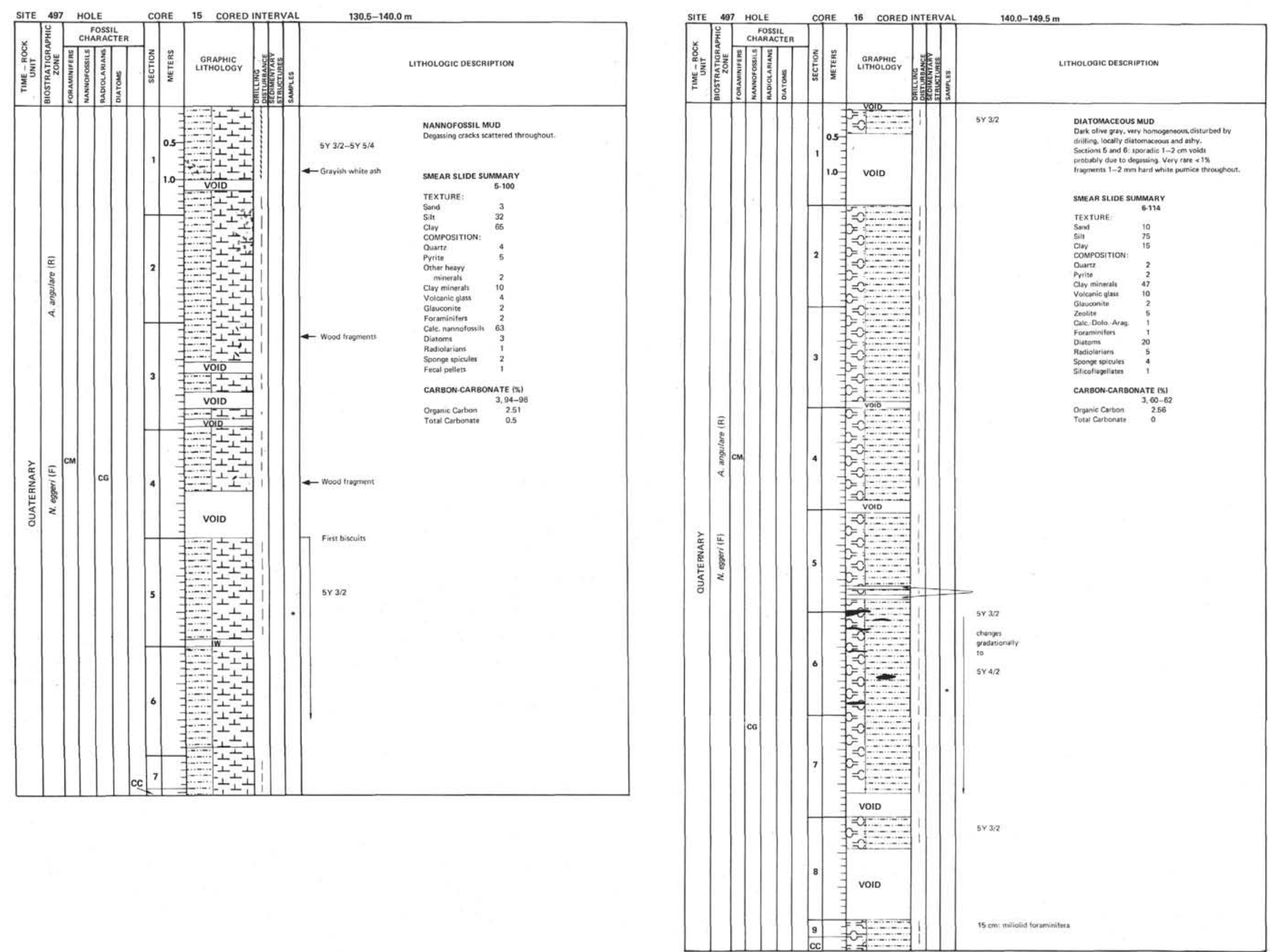

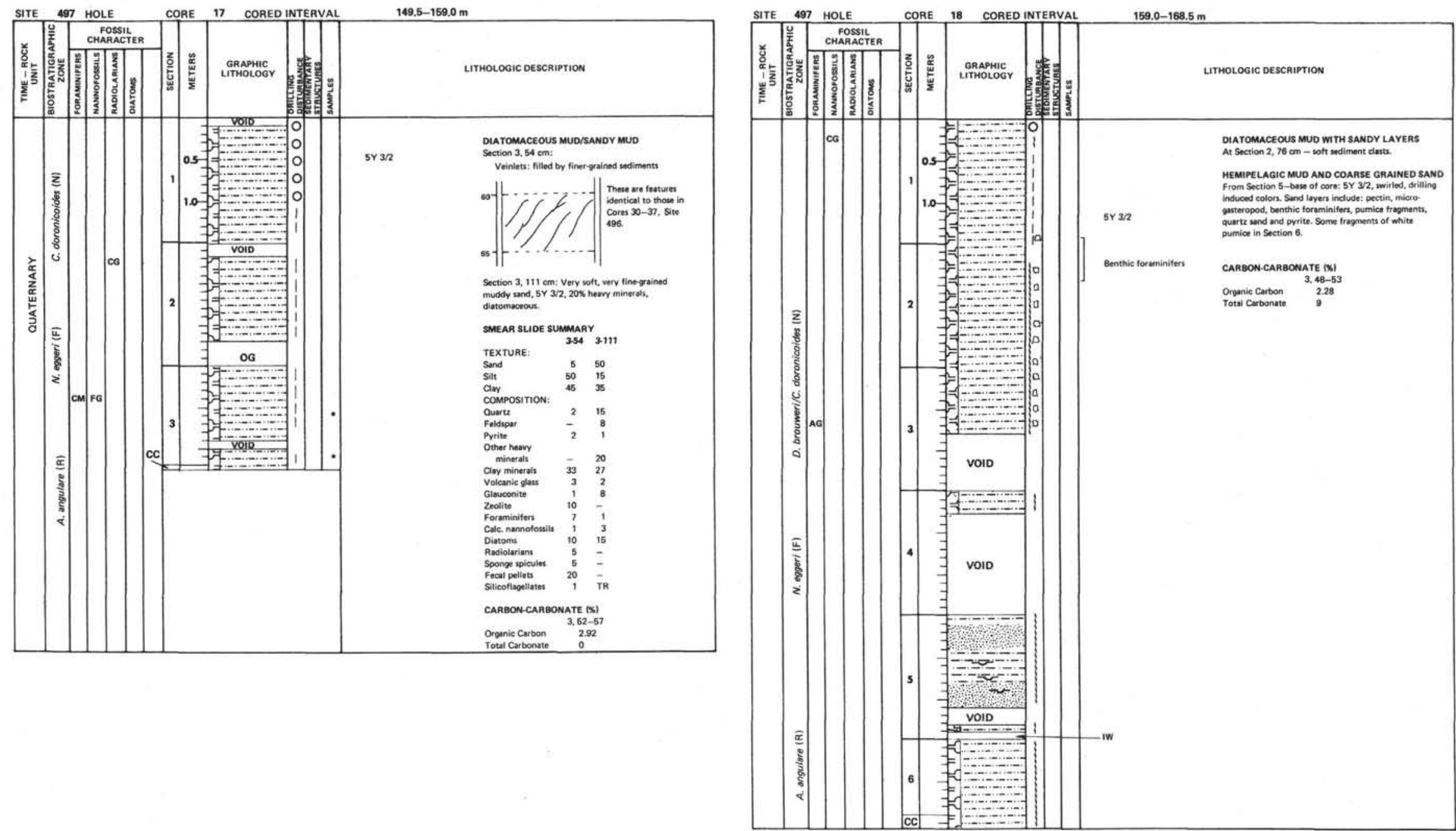

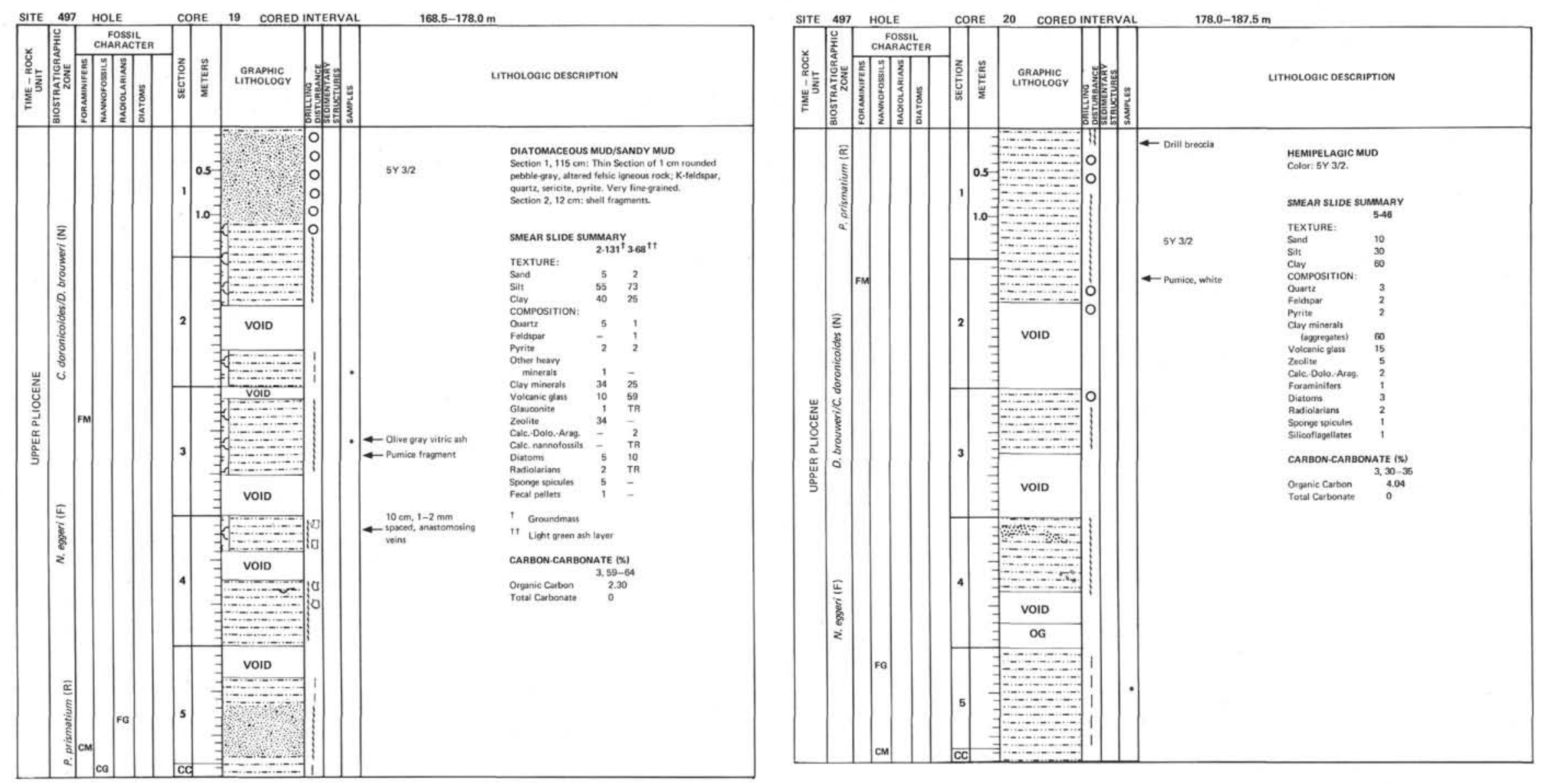

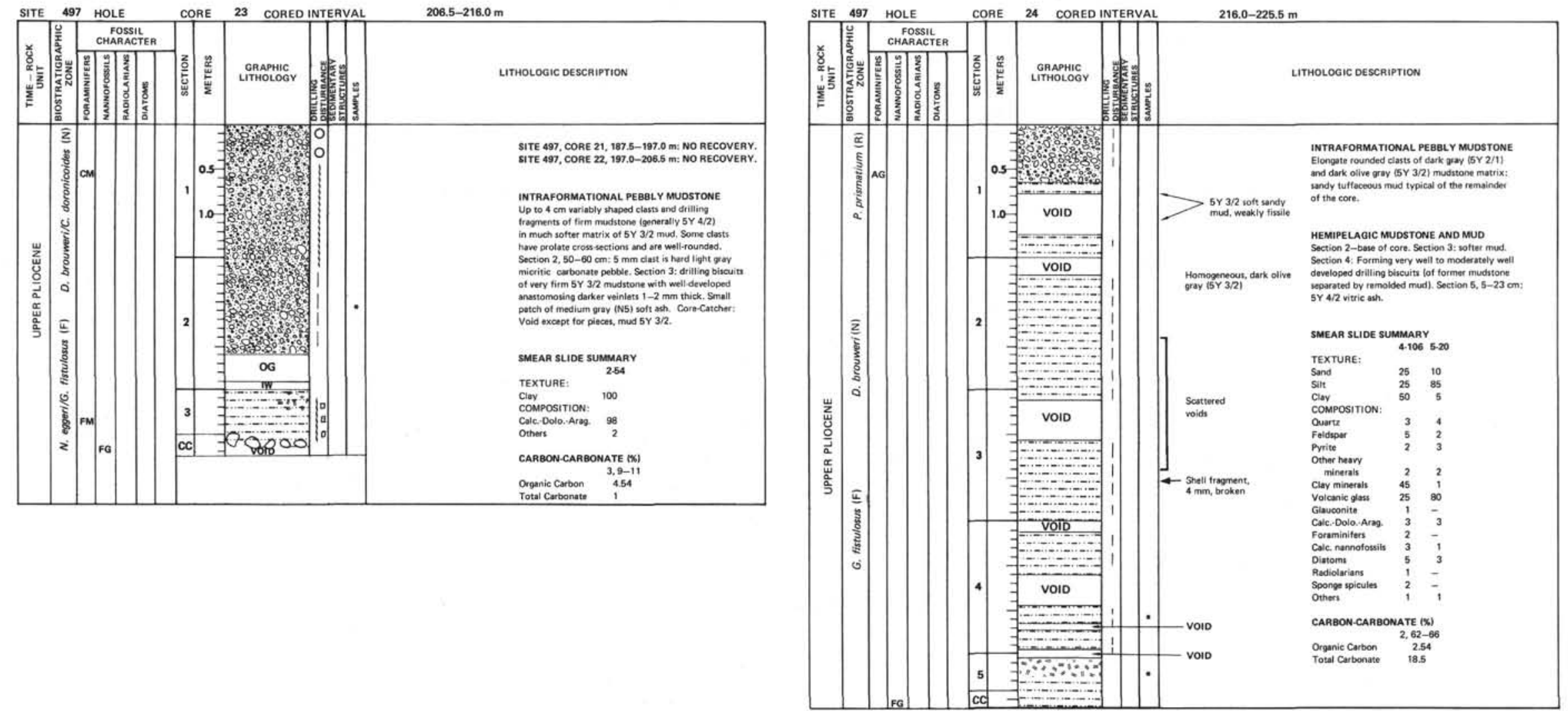

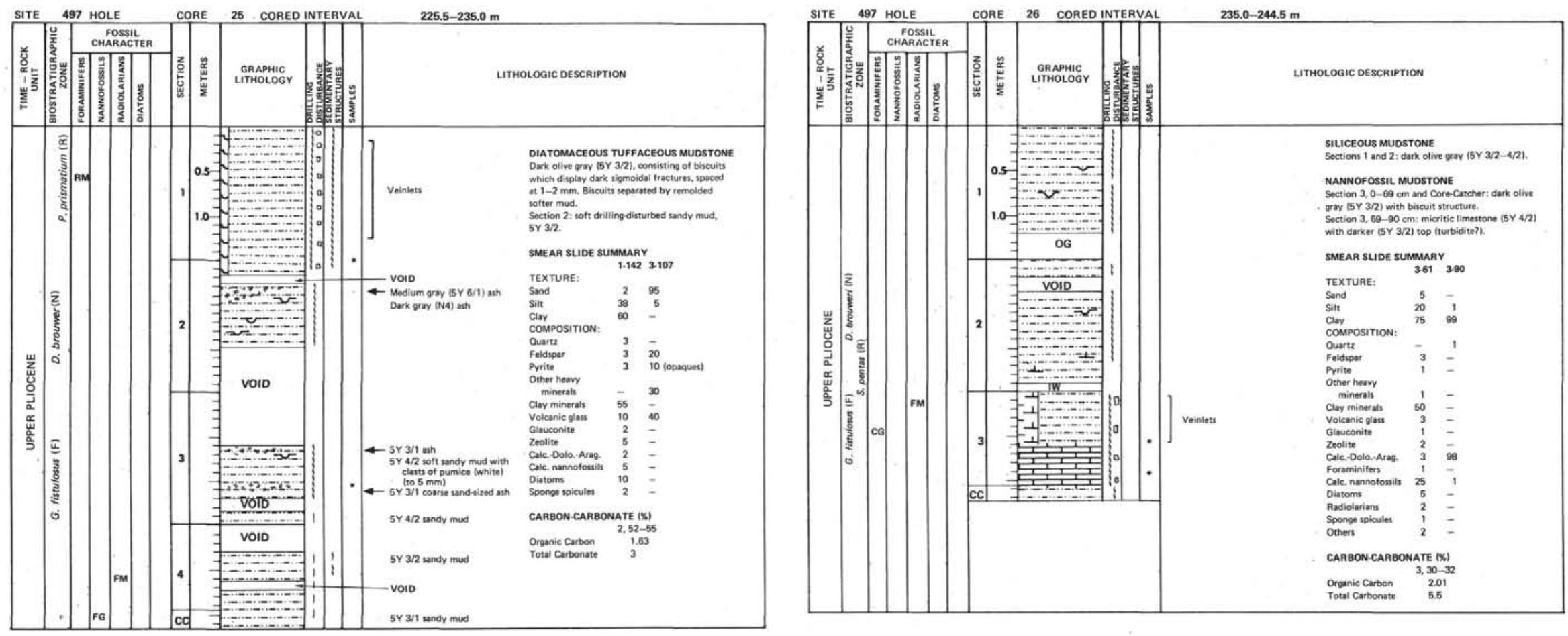


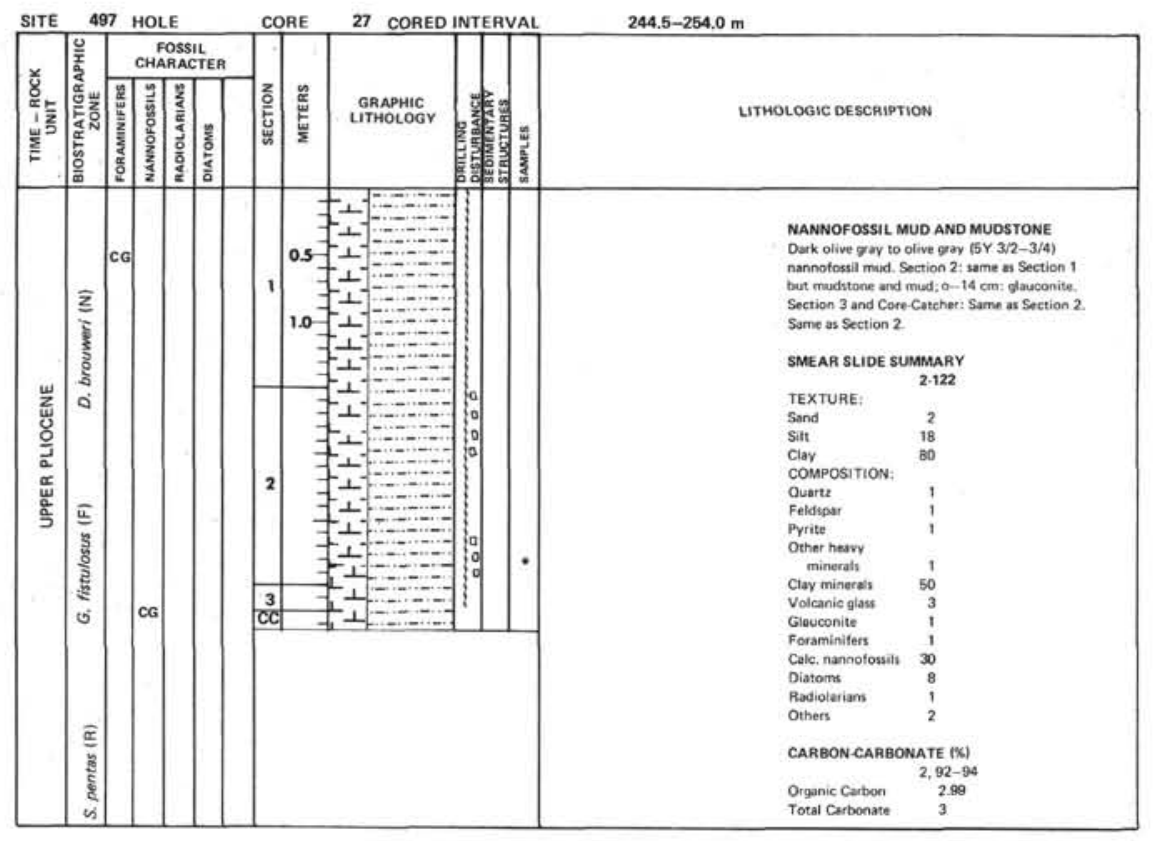

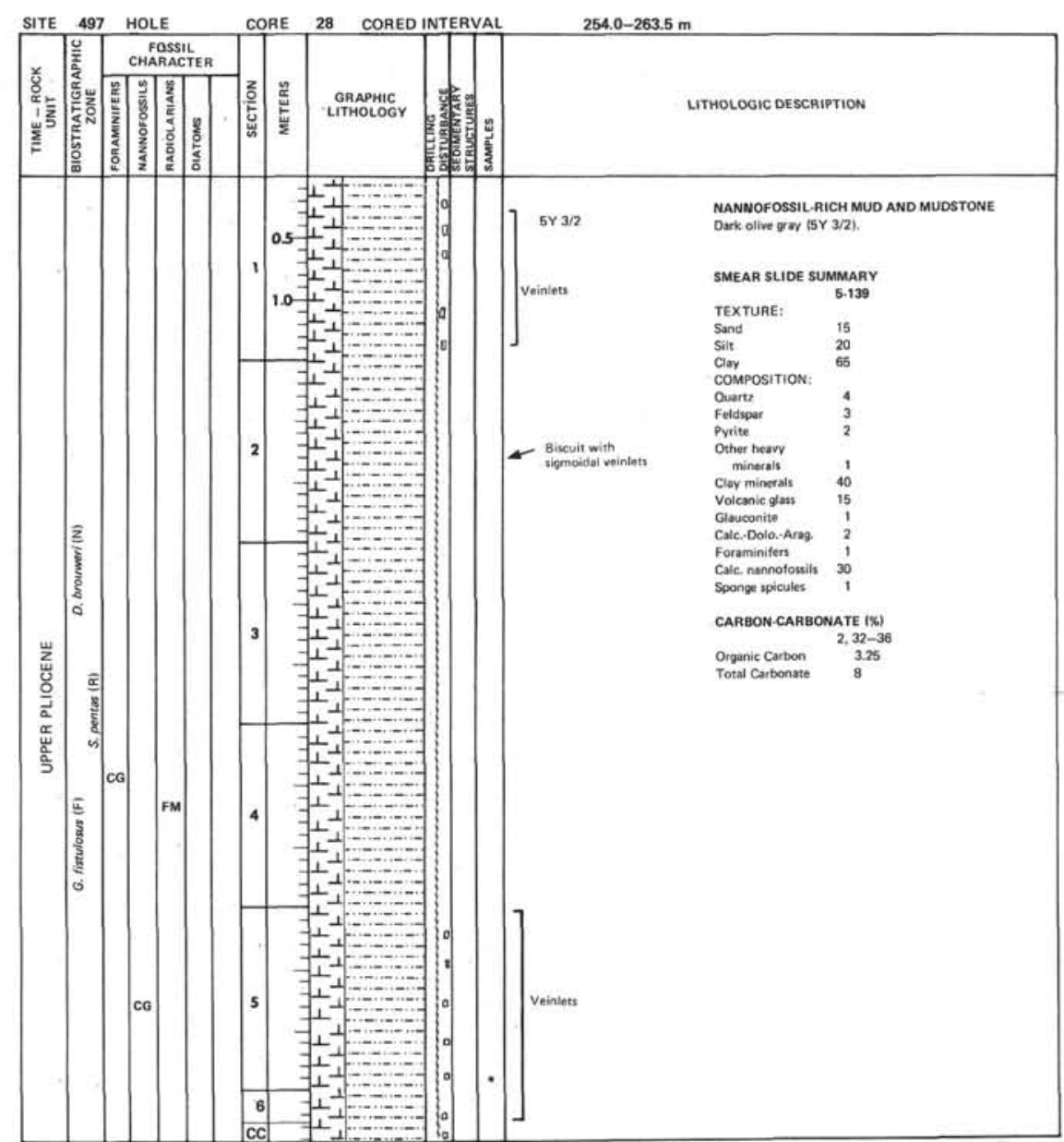



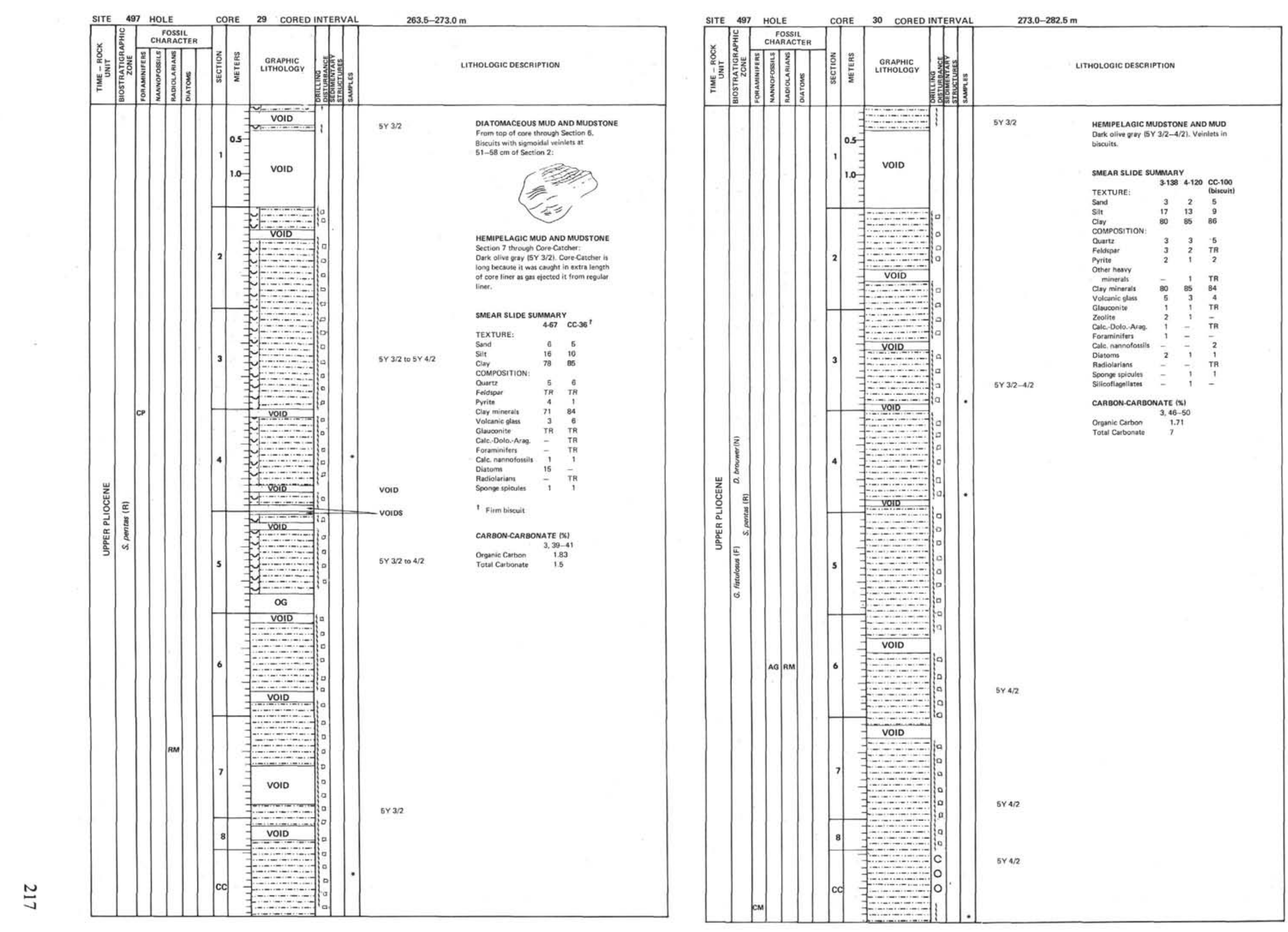

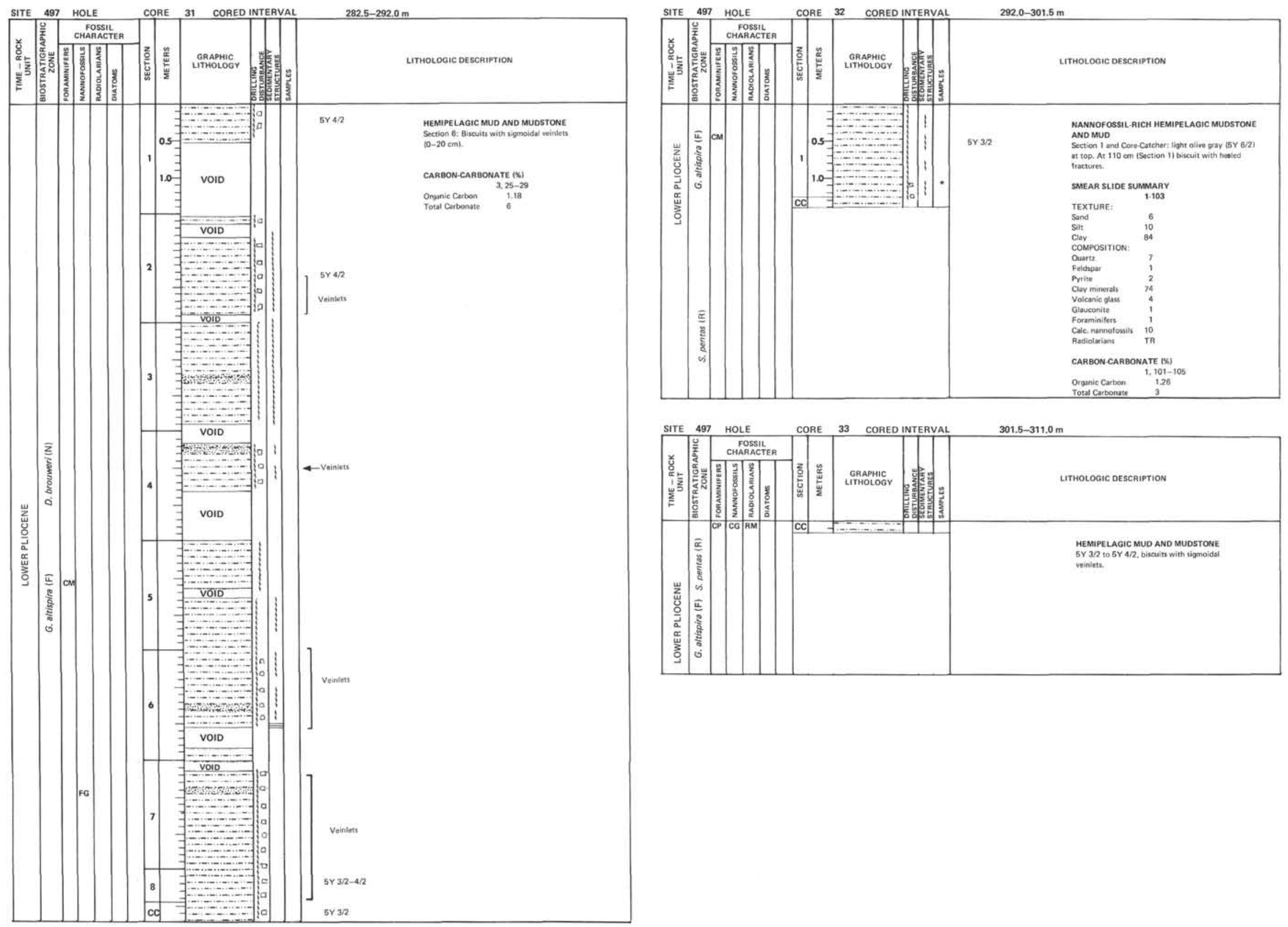

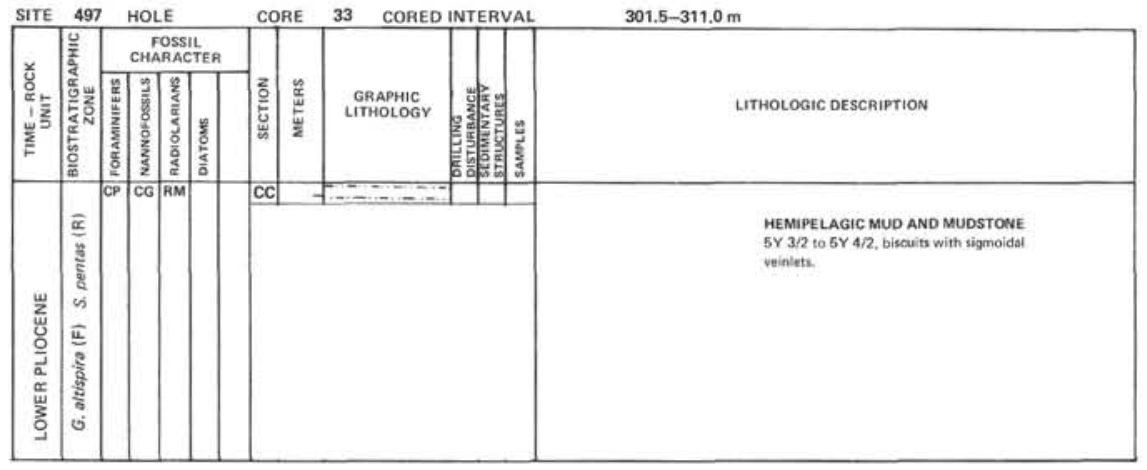



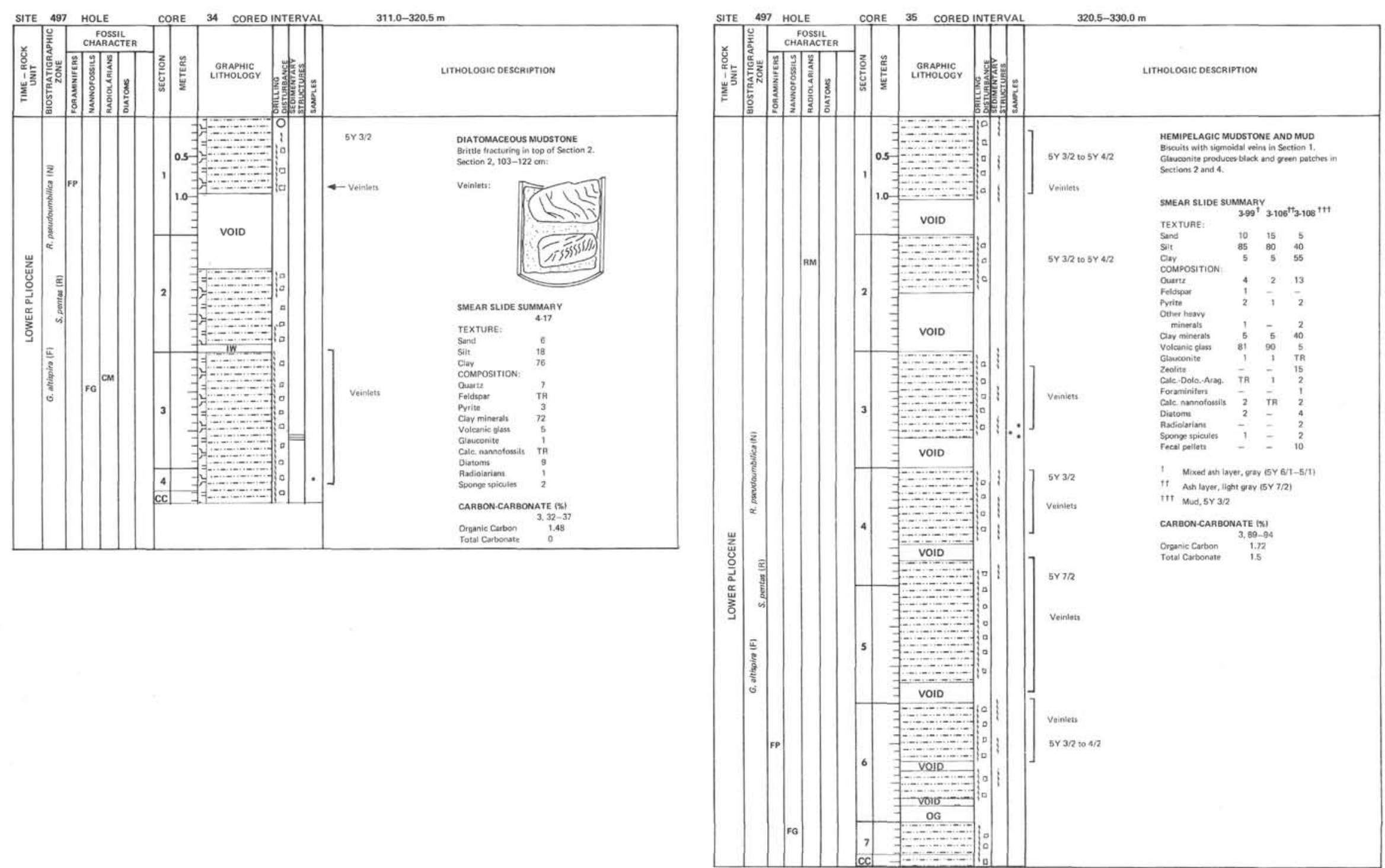

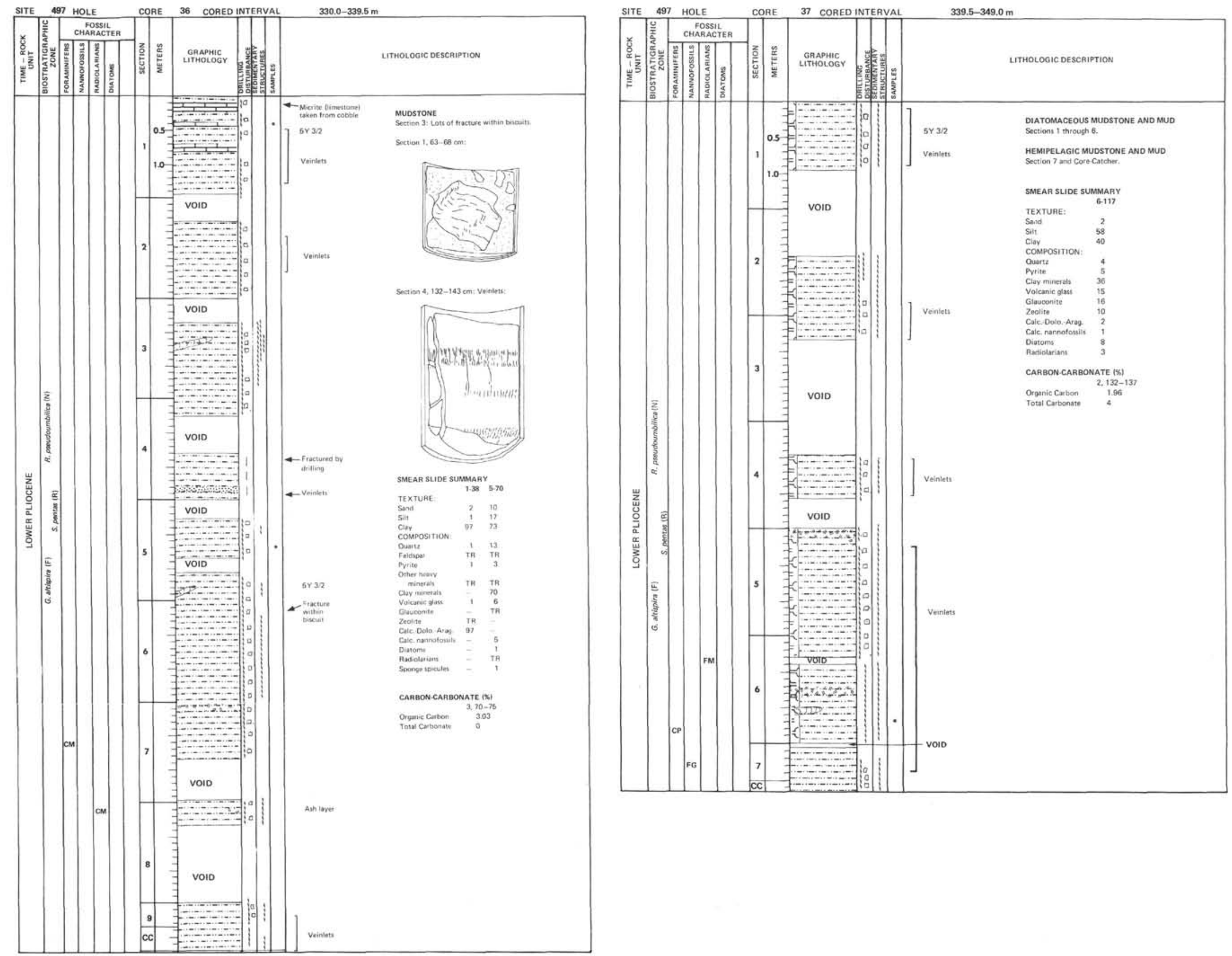

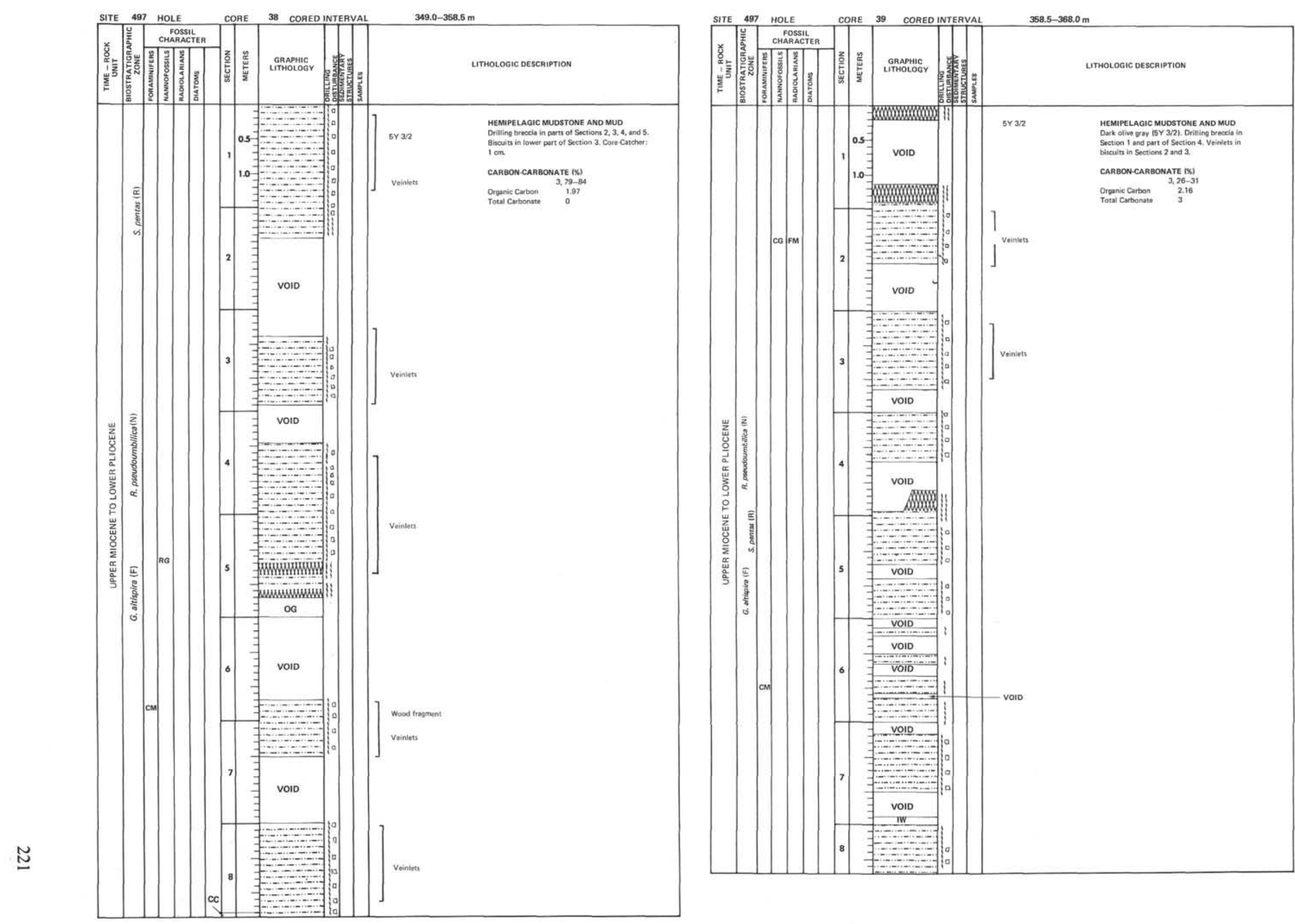

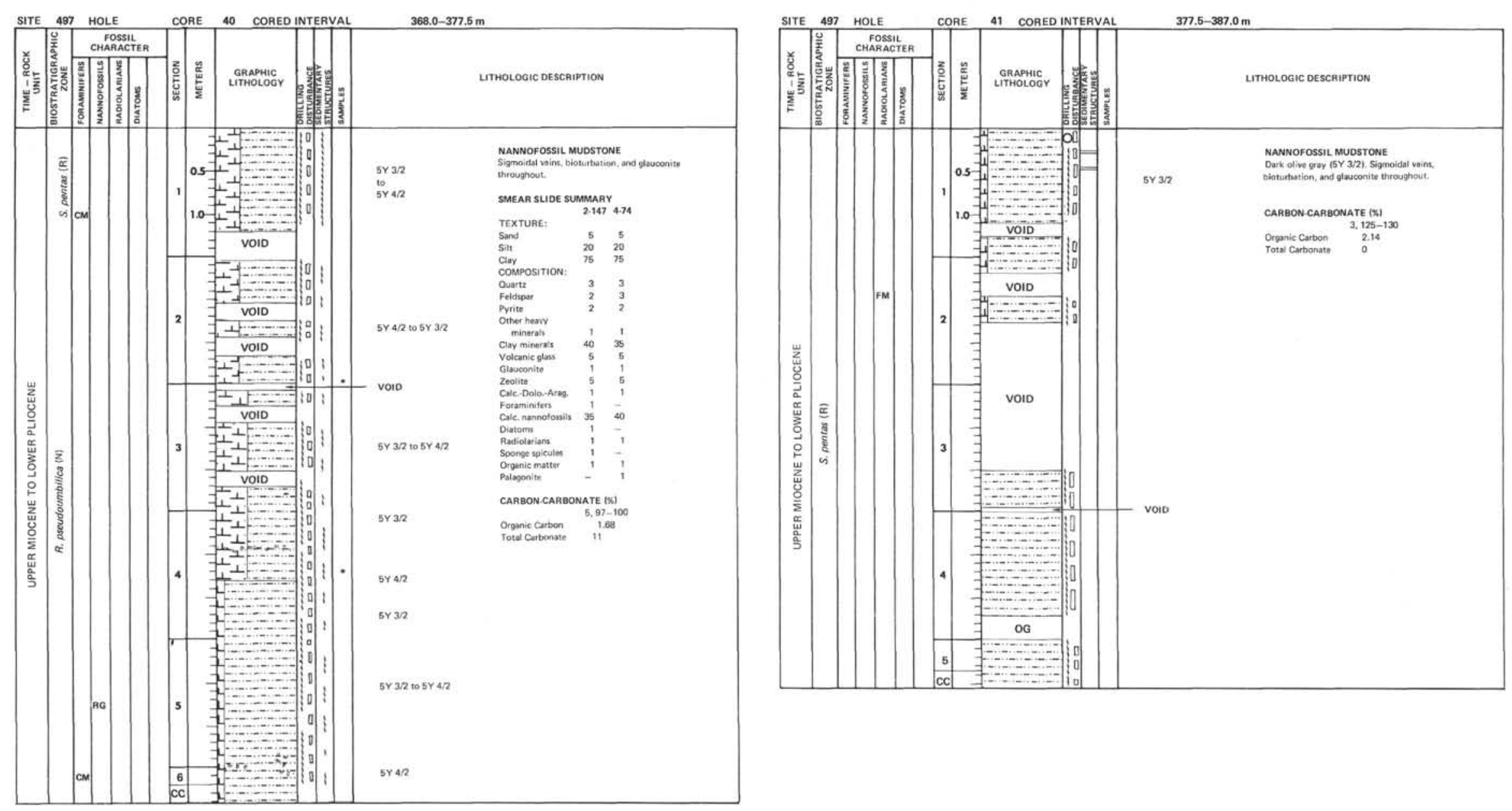


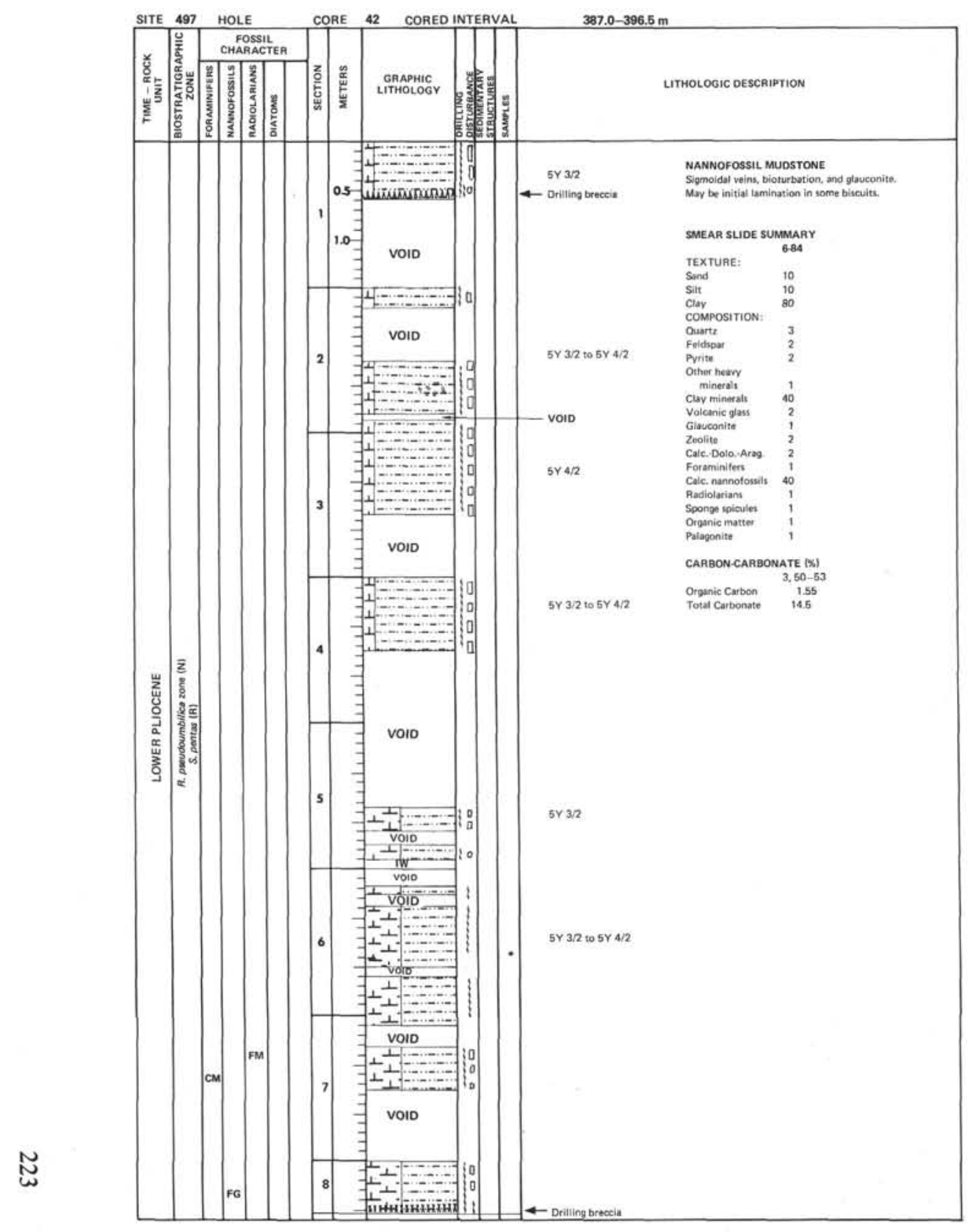




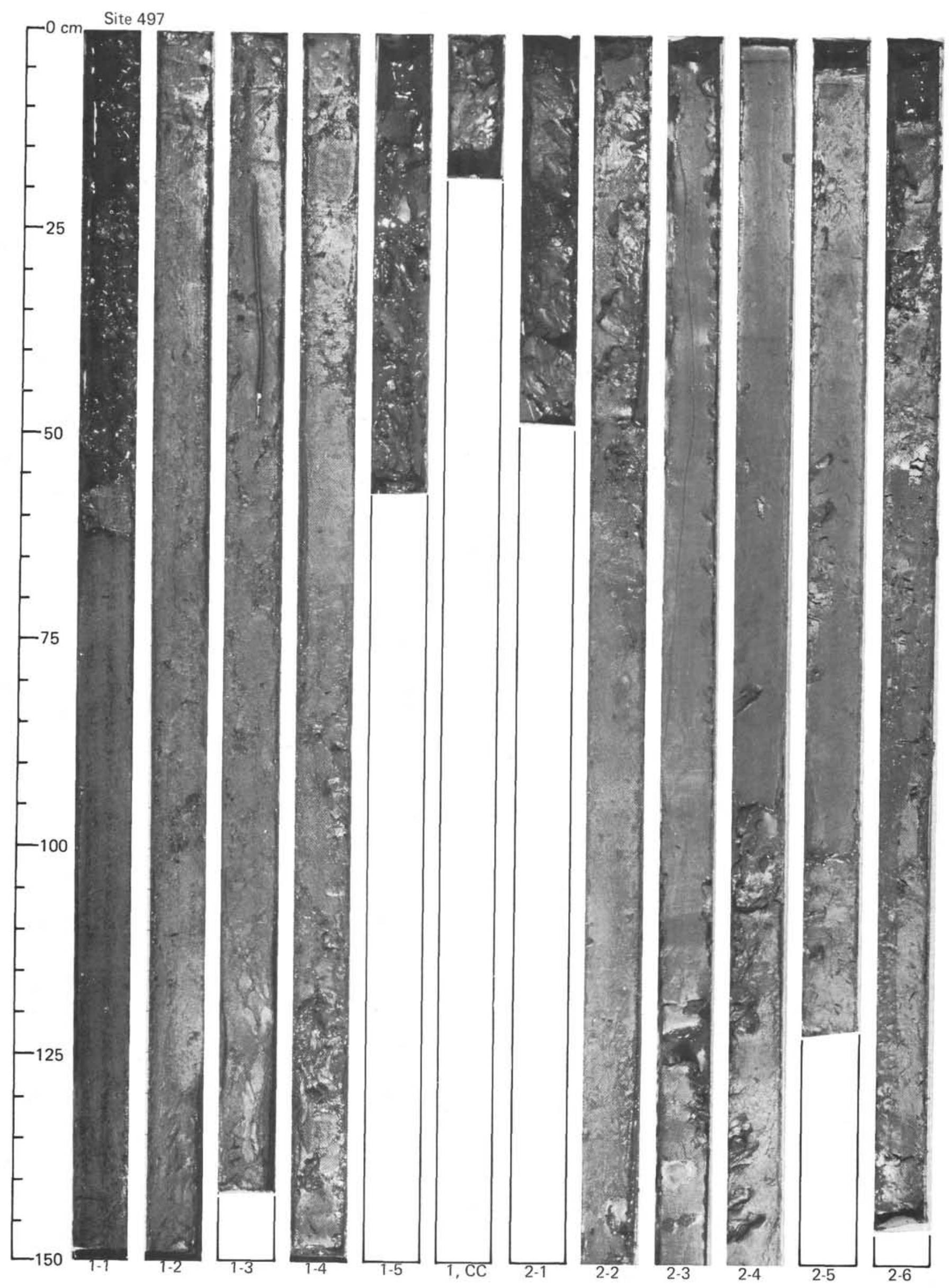




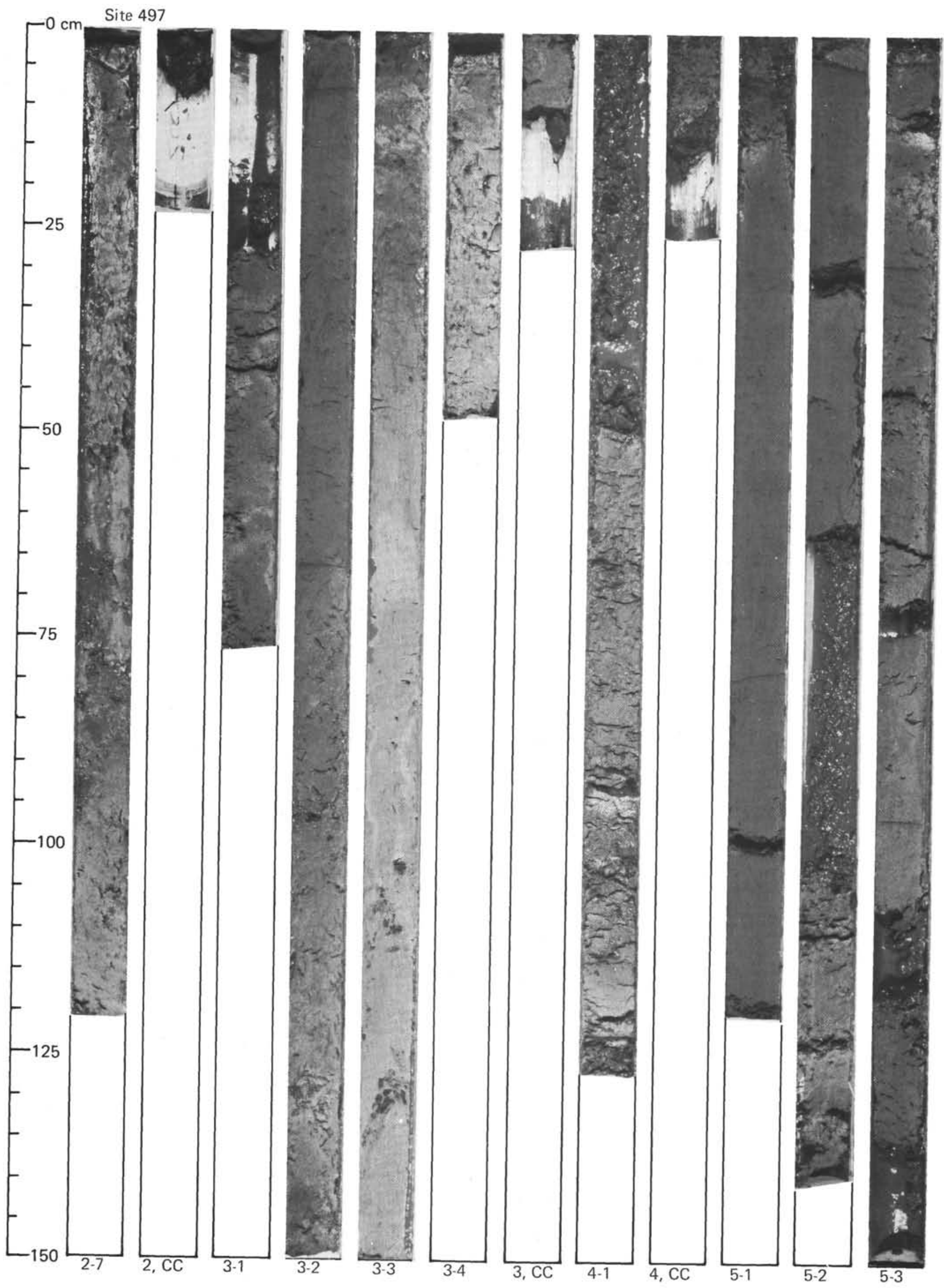




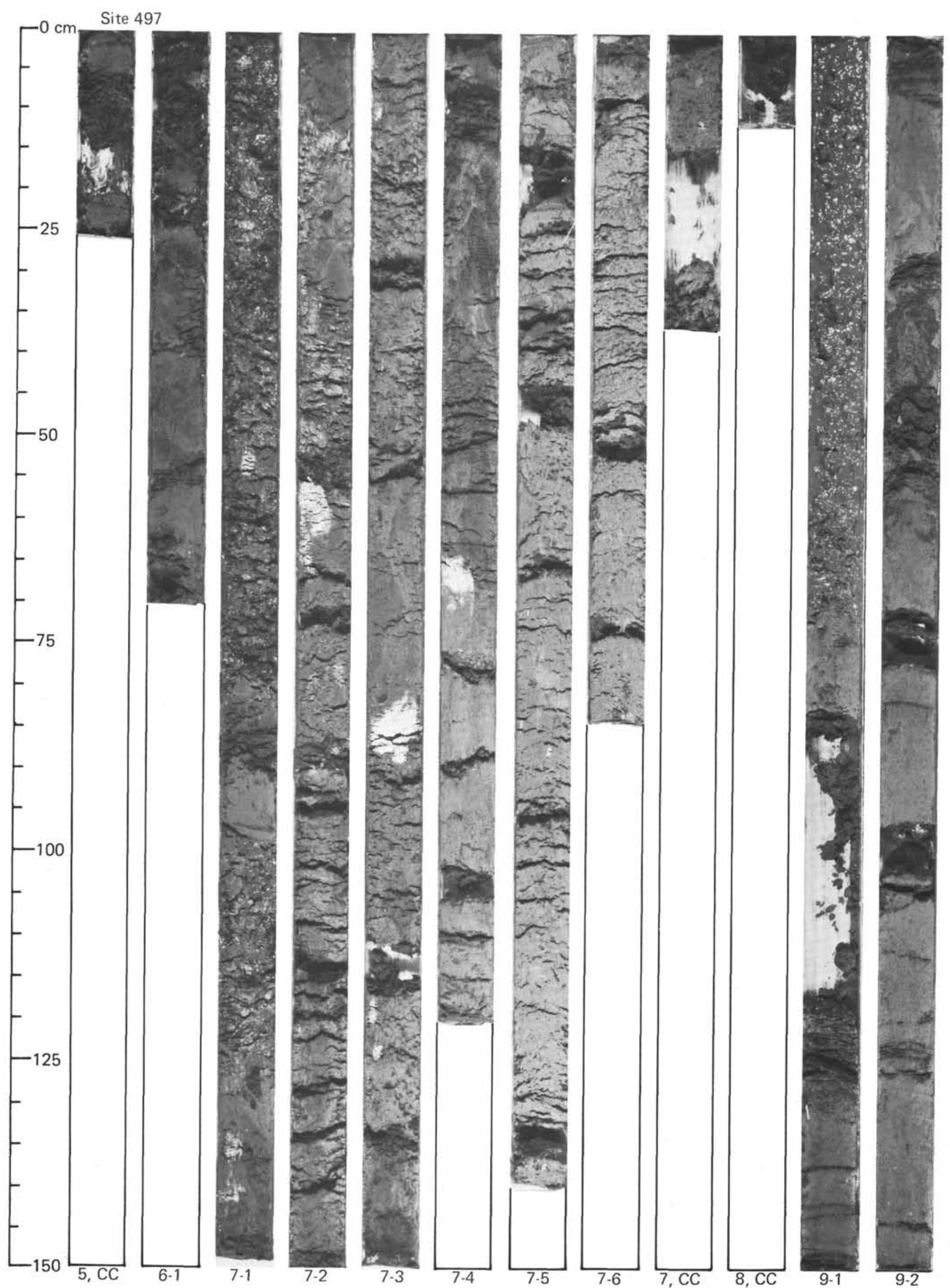




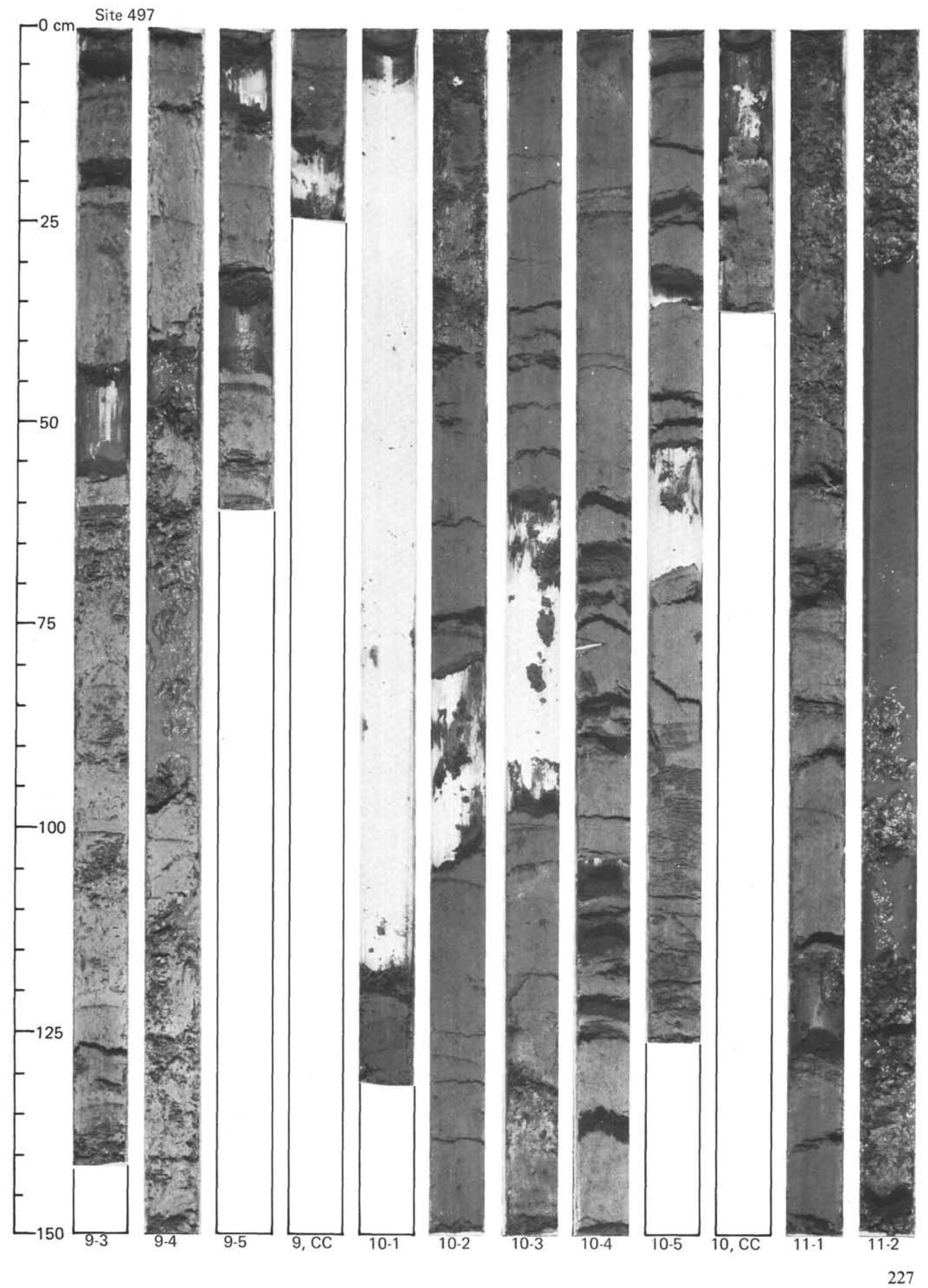




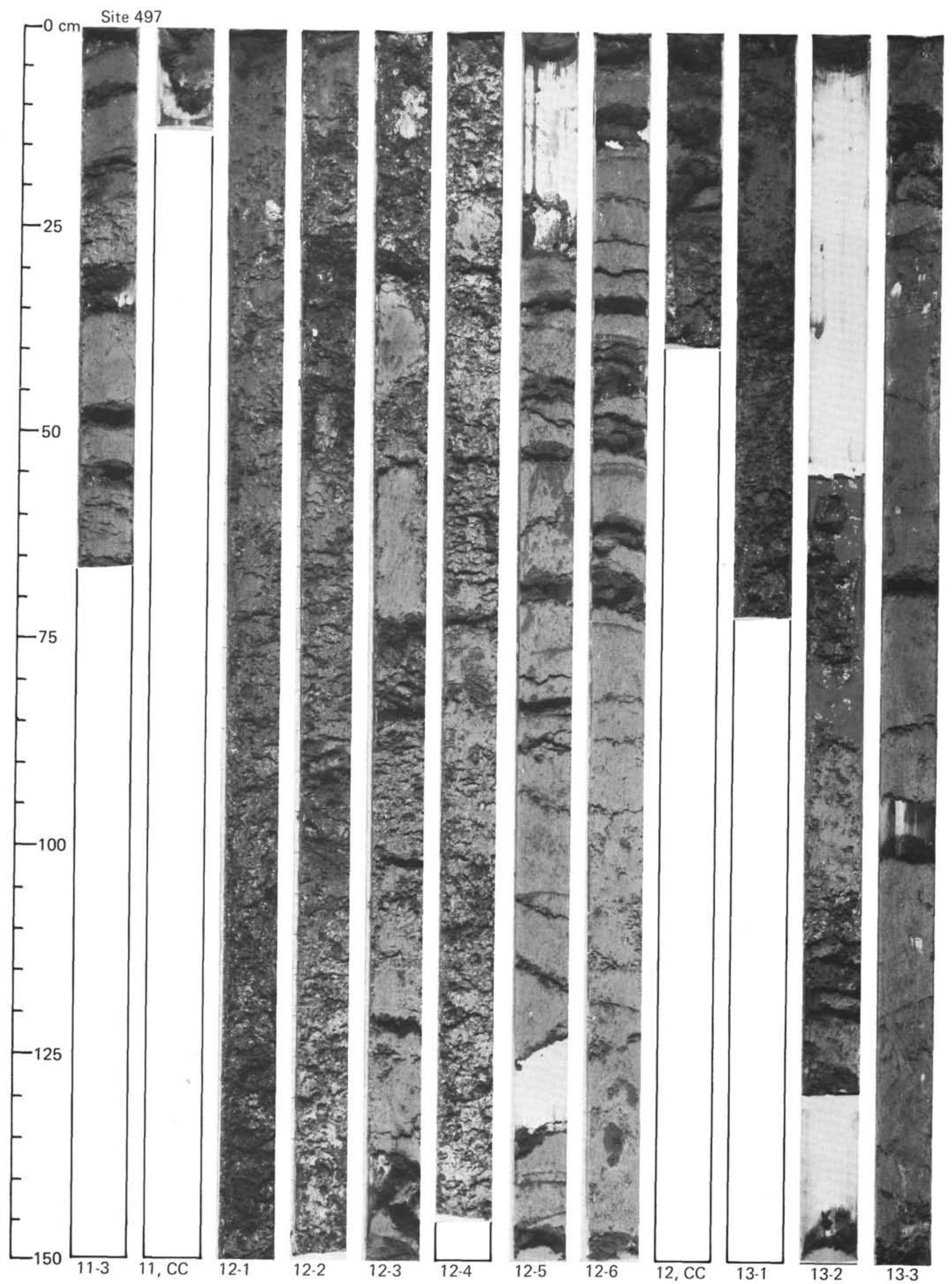




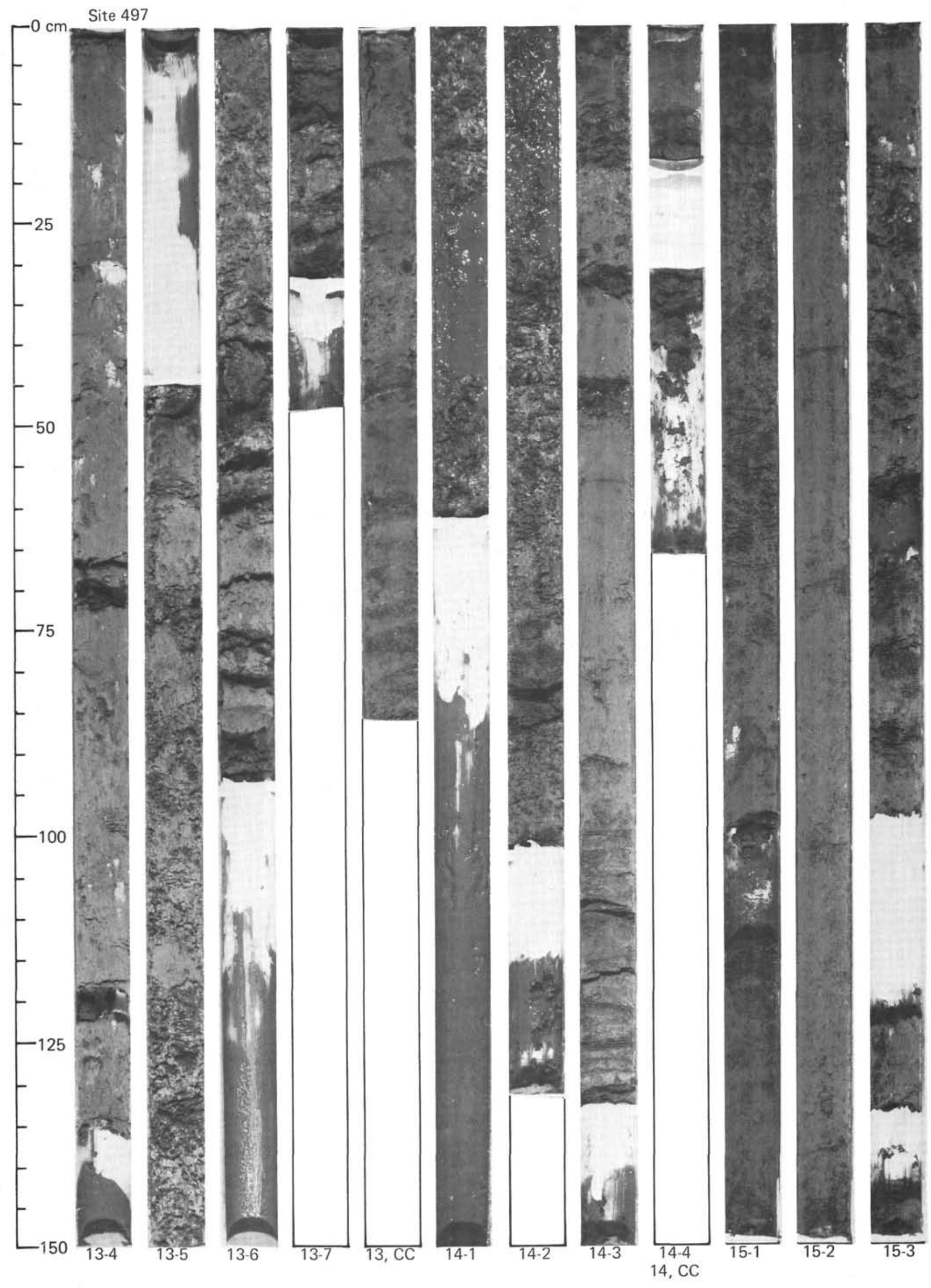




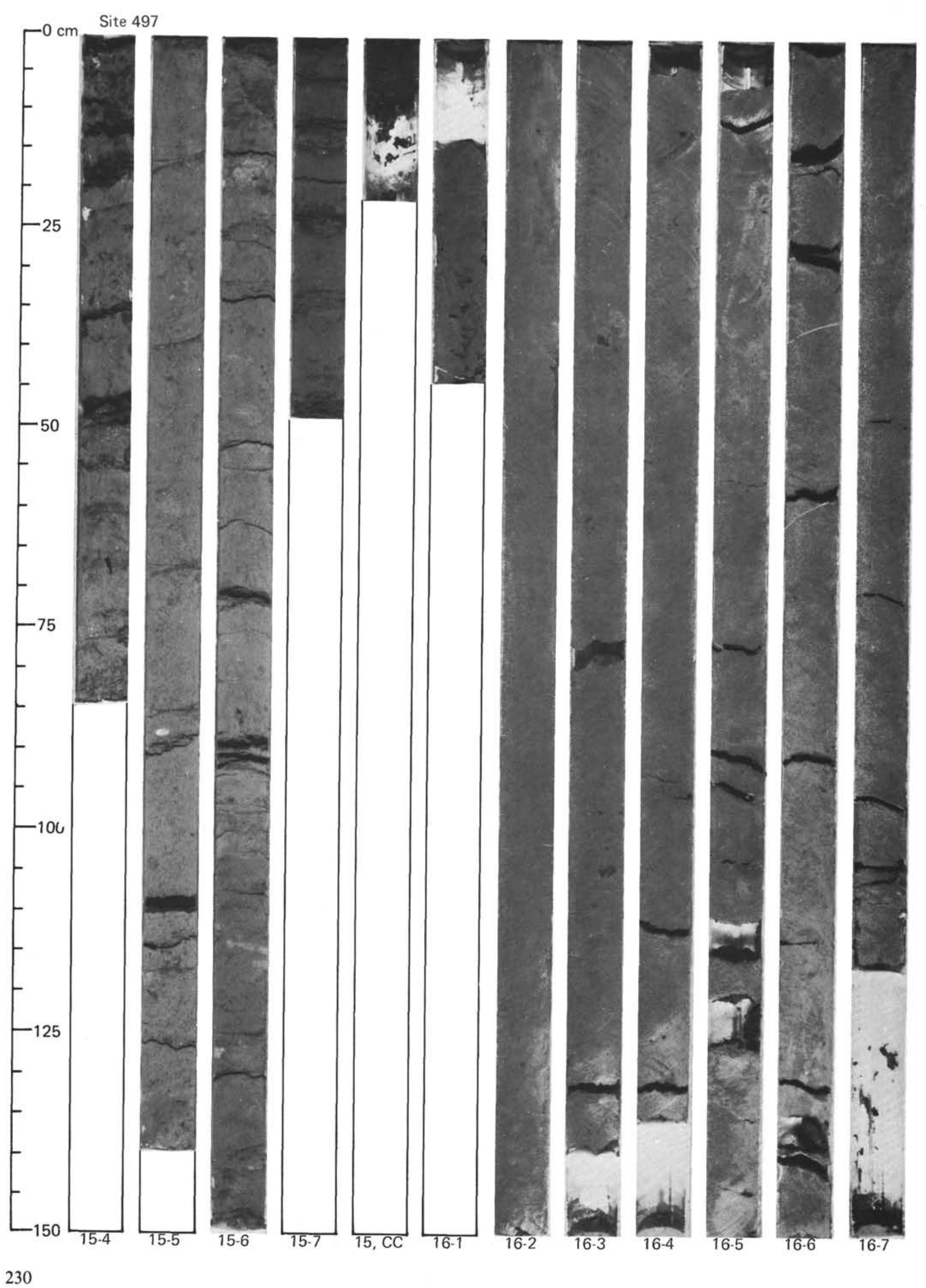



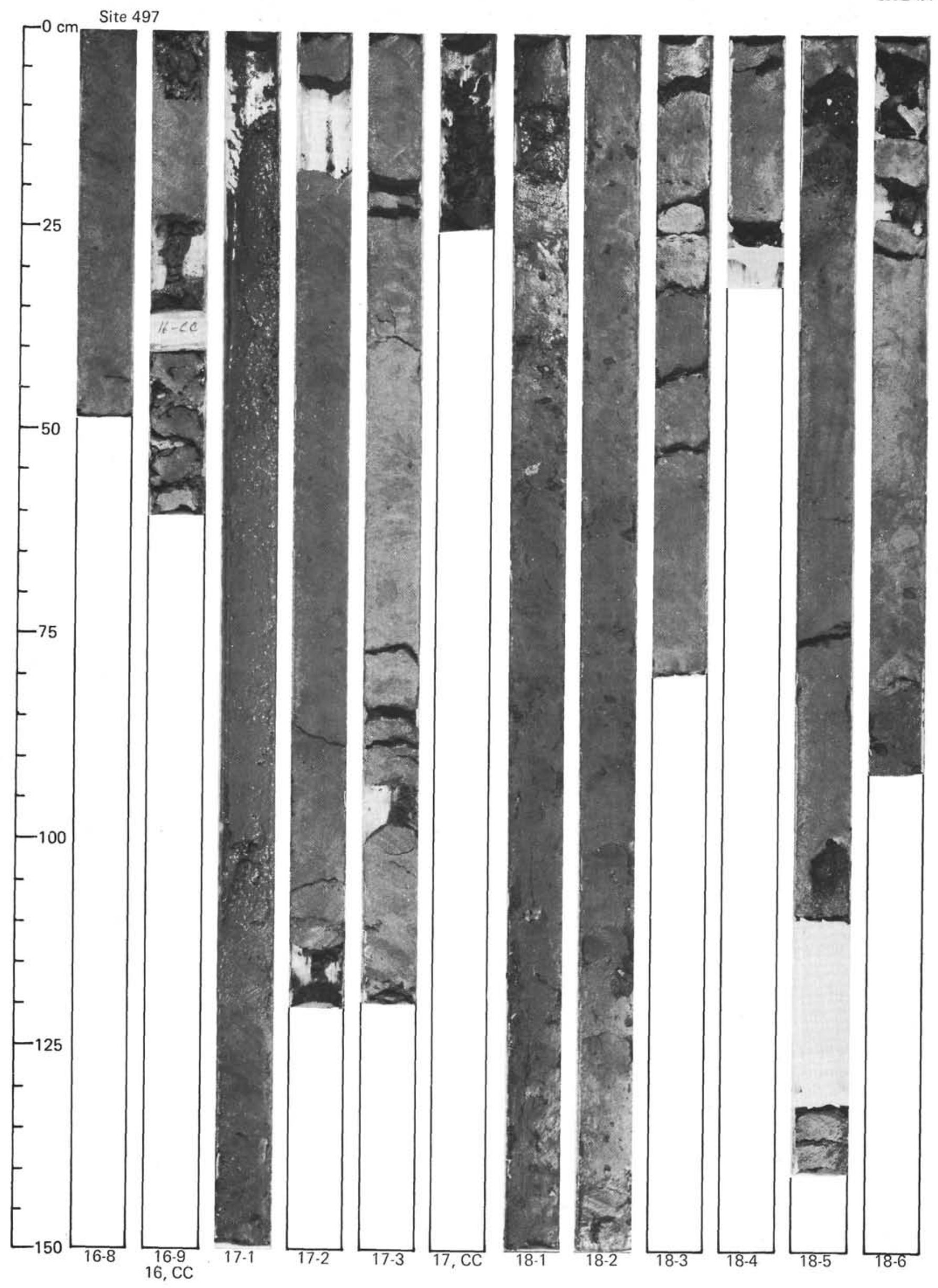


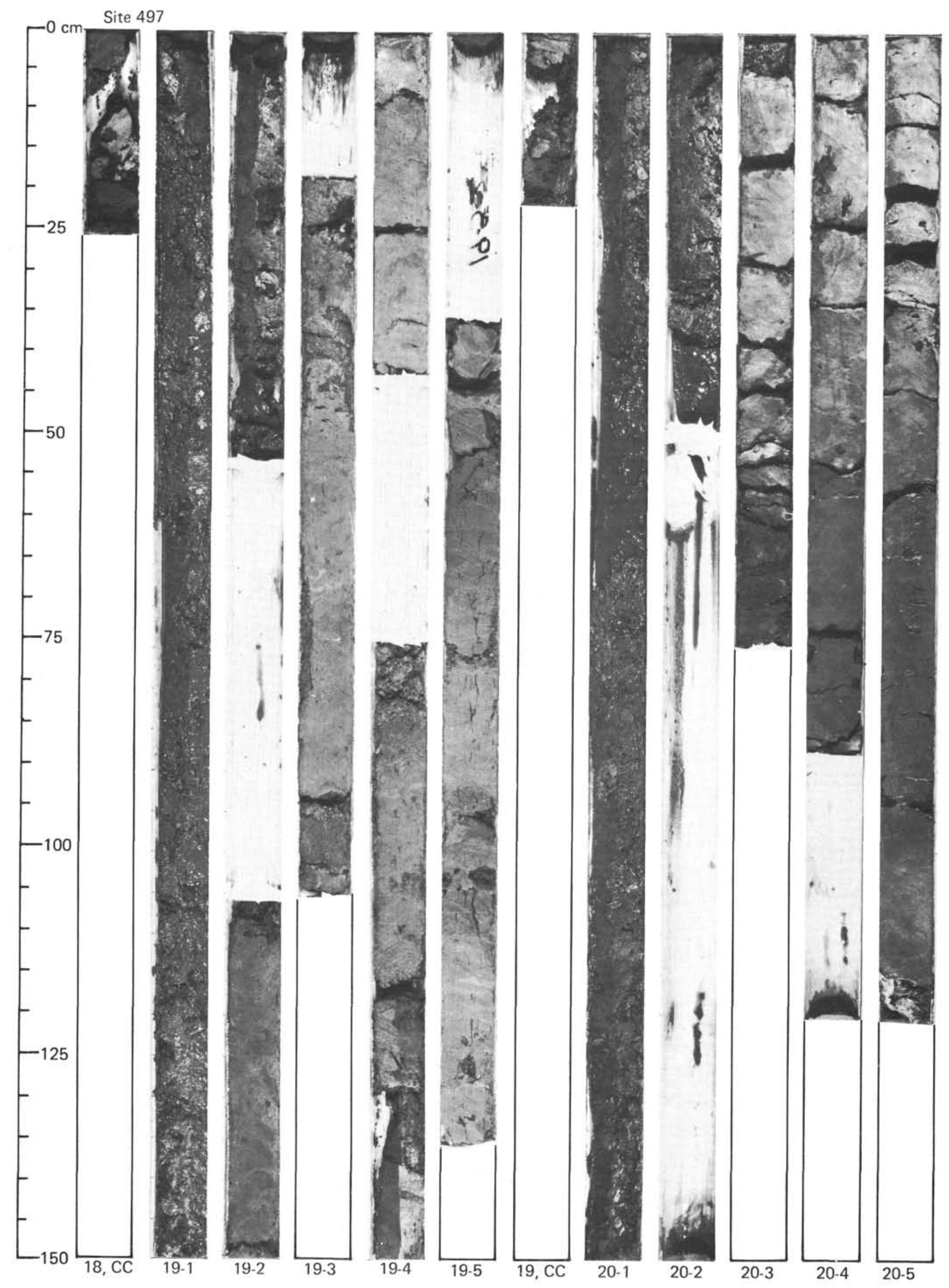



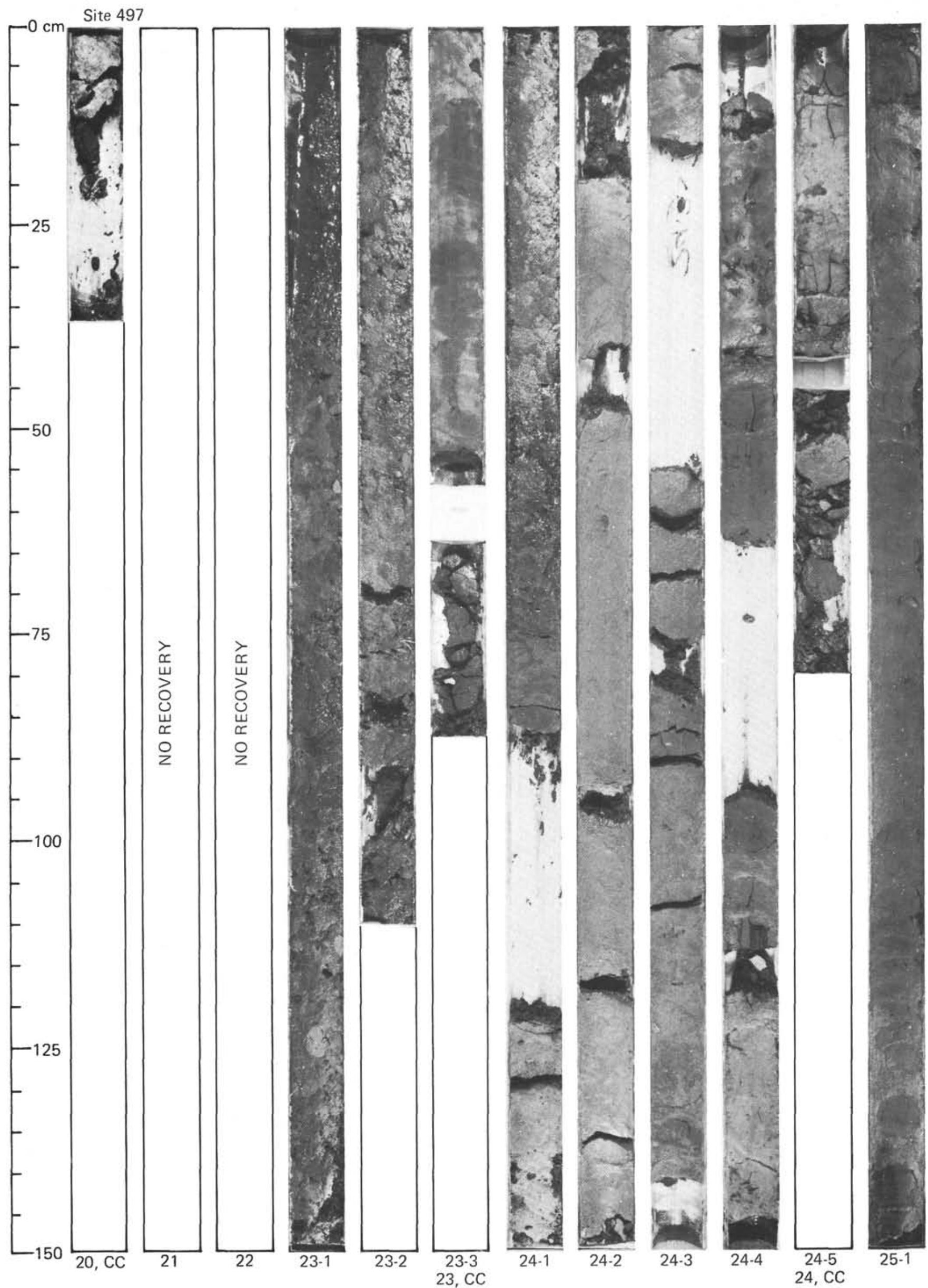


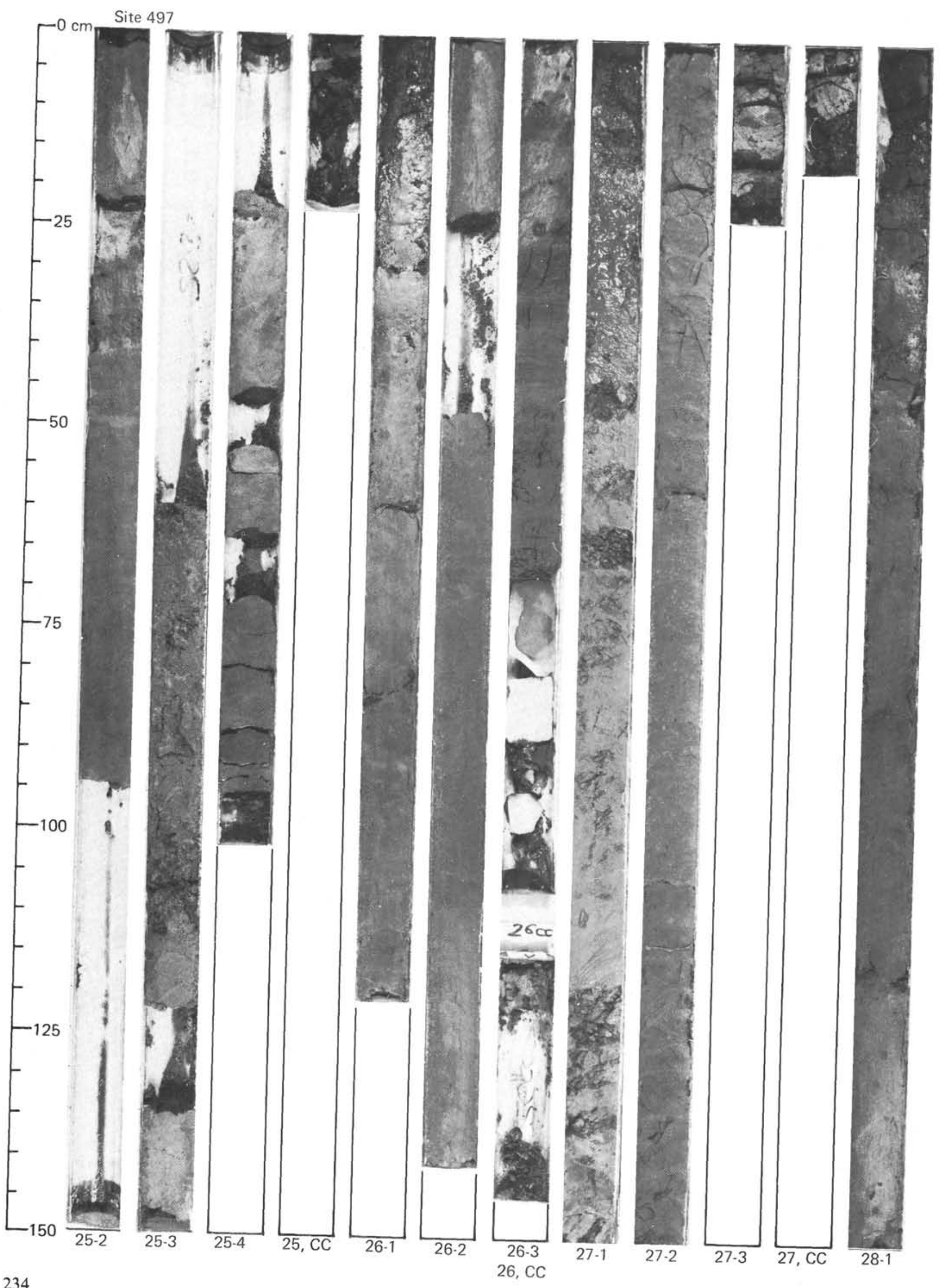




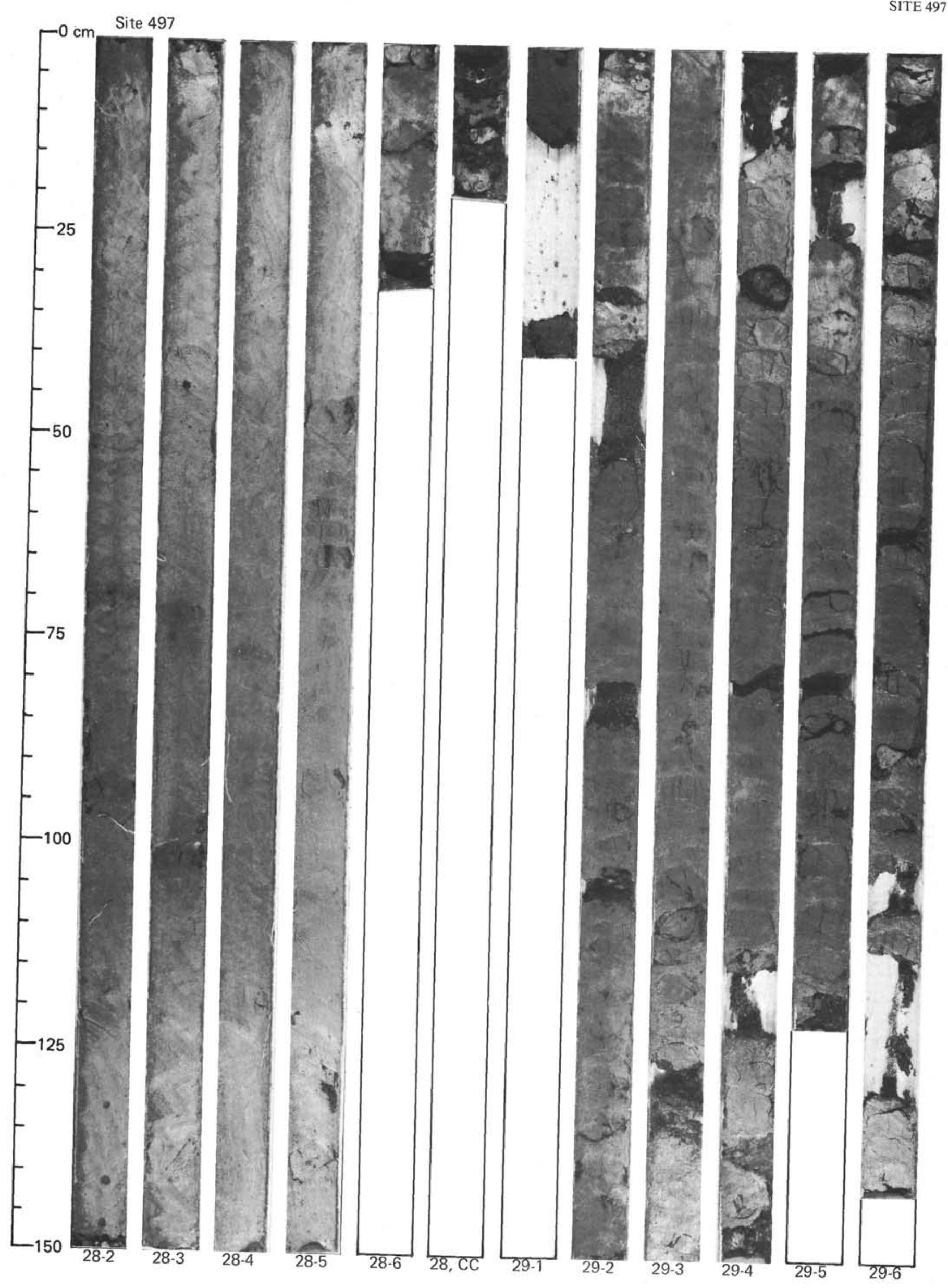




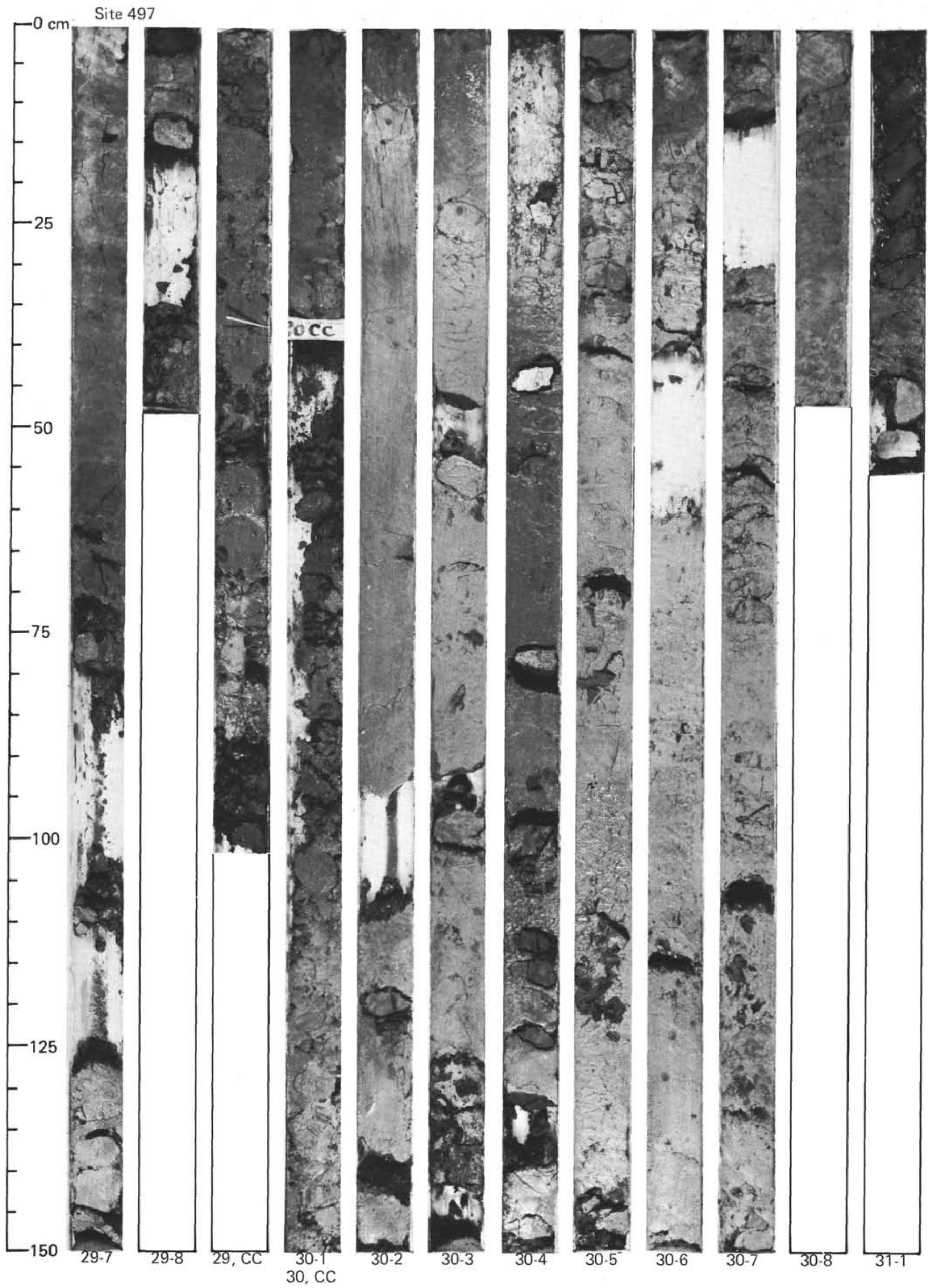




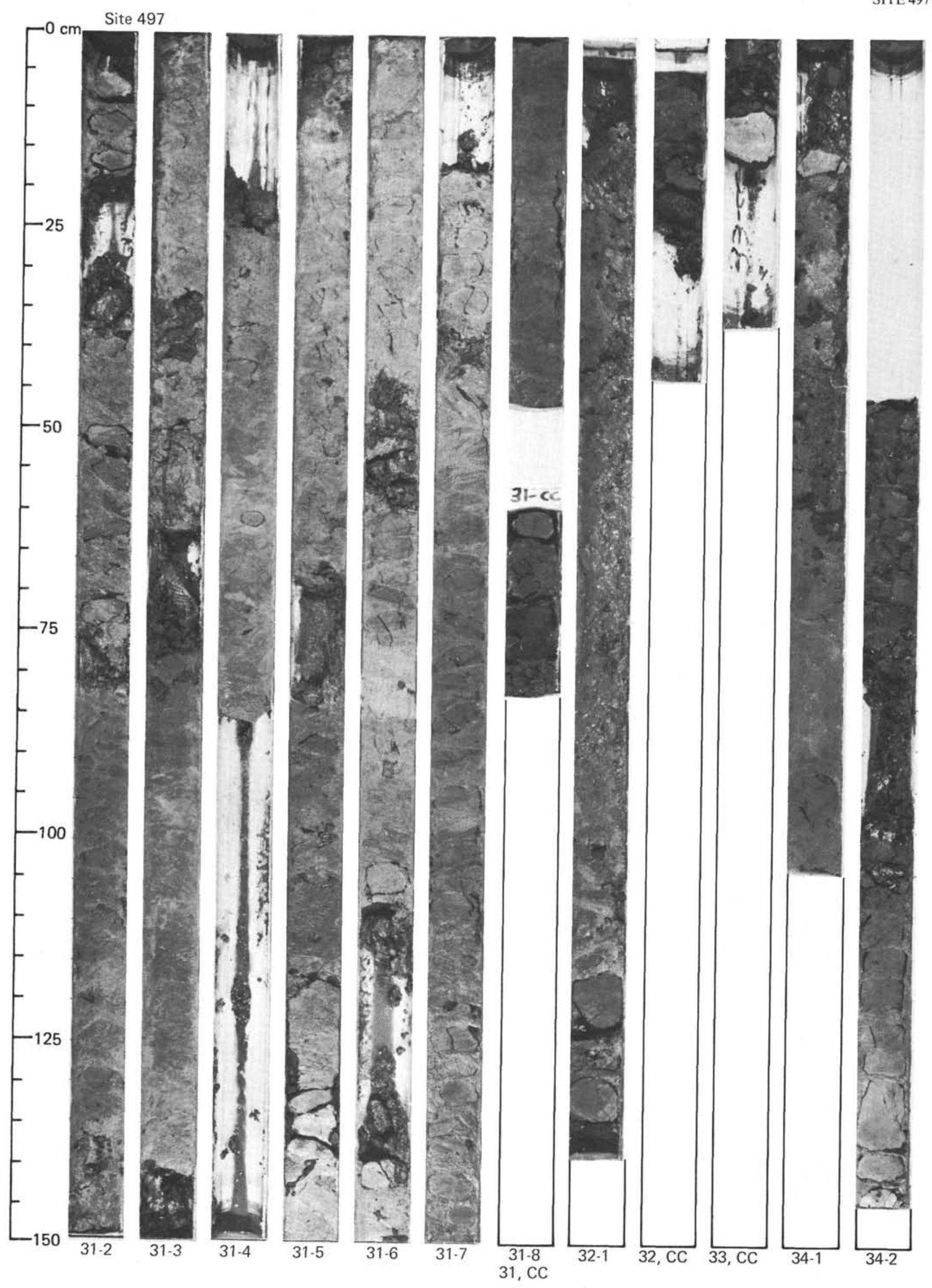

SITE 497 


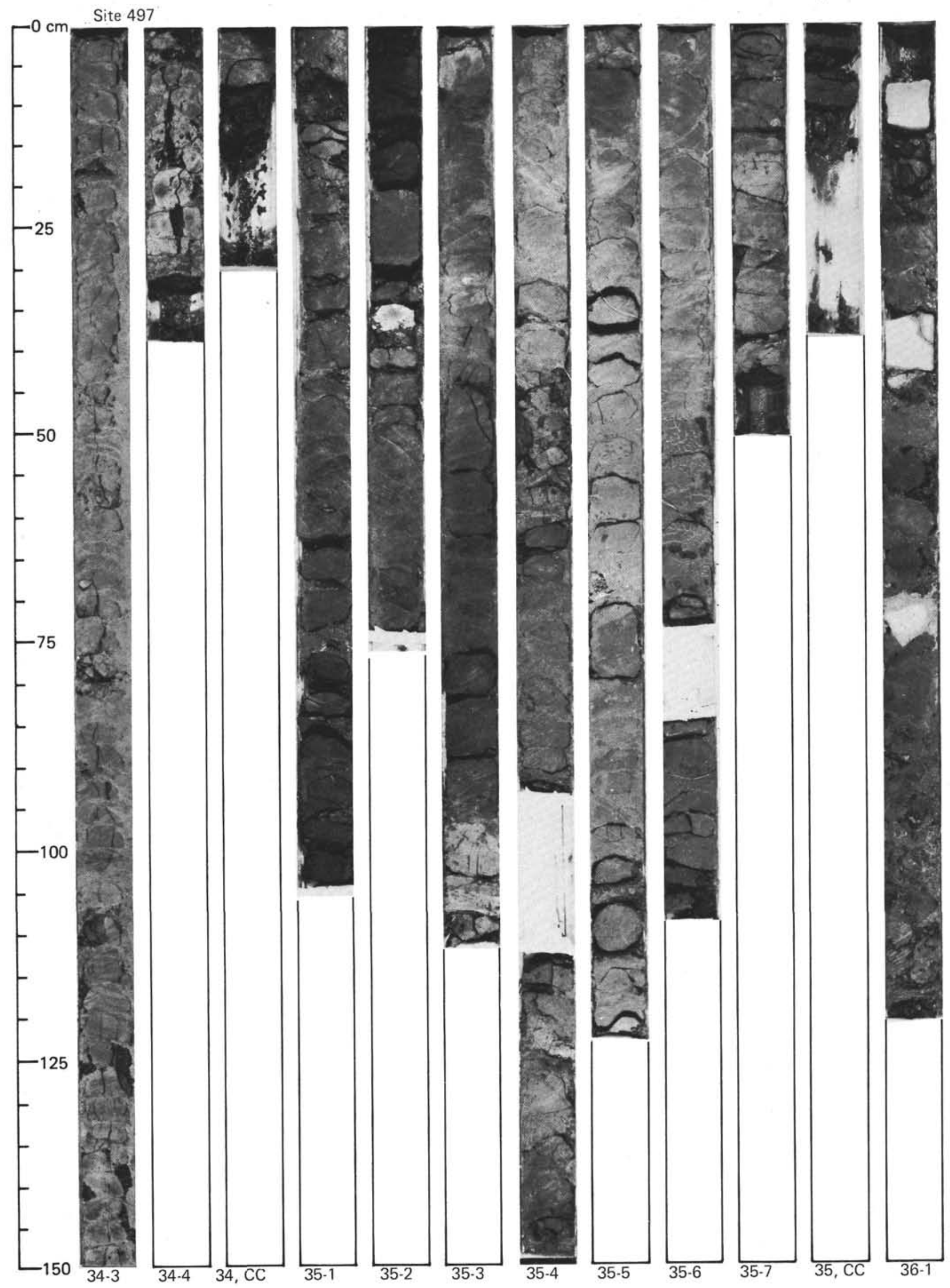



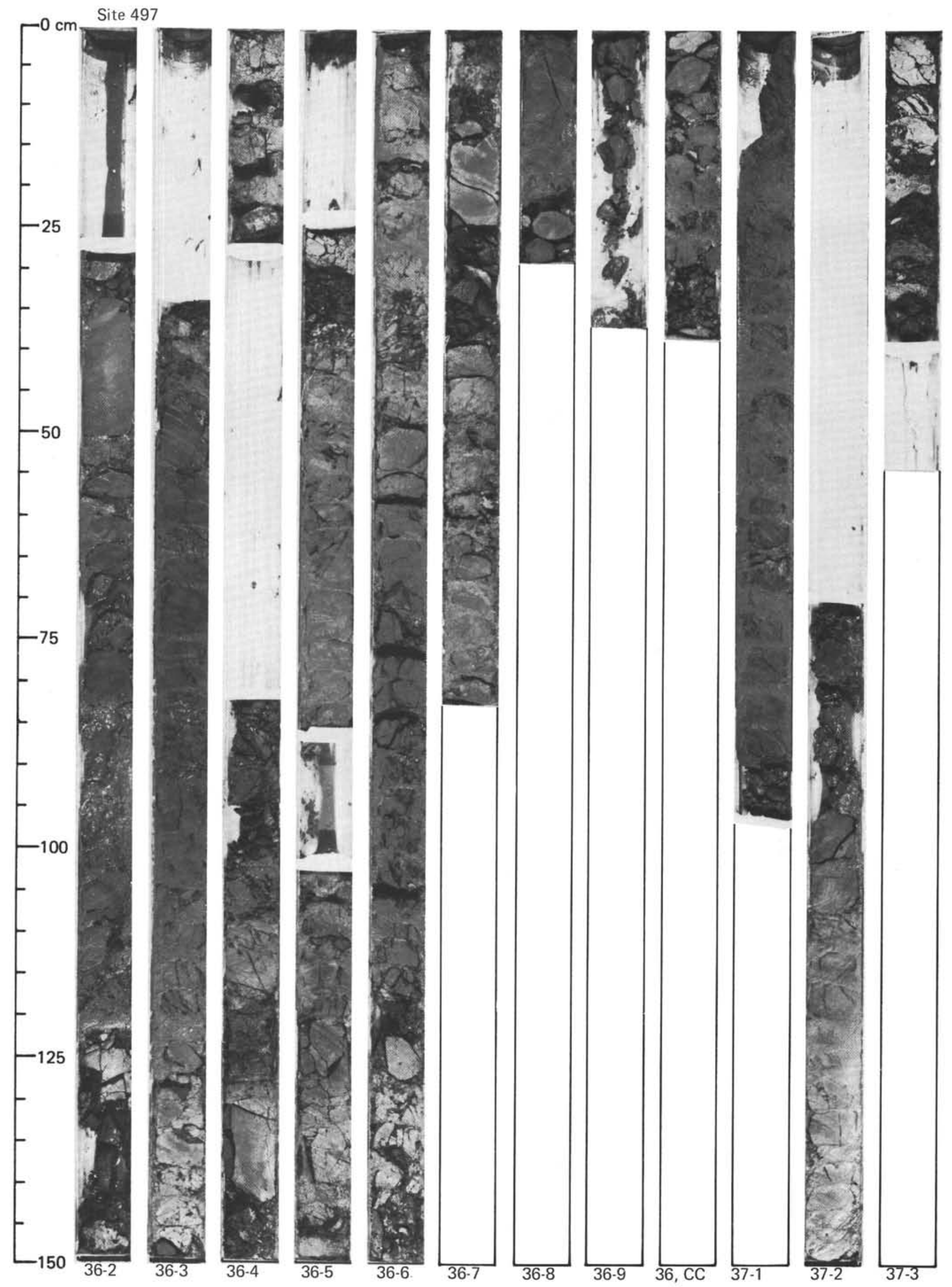


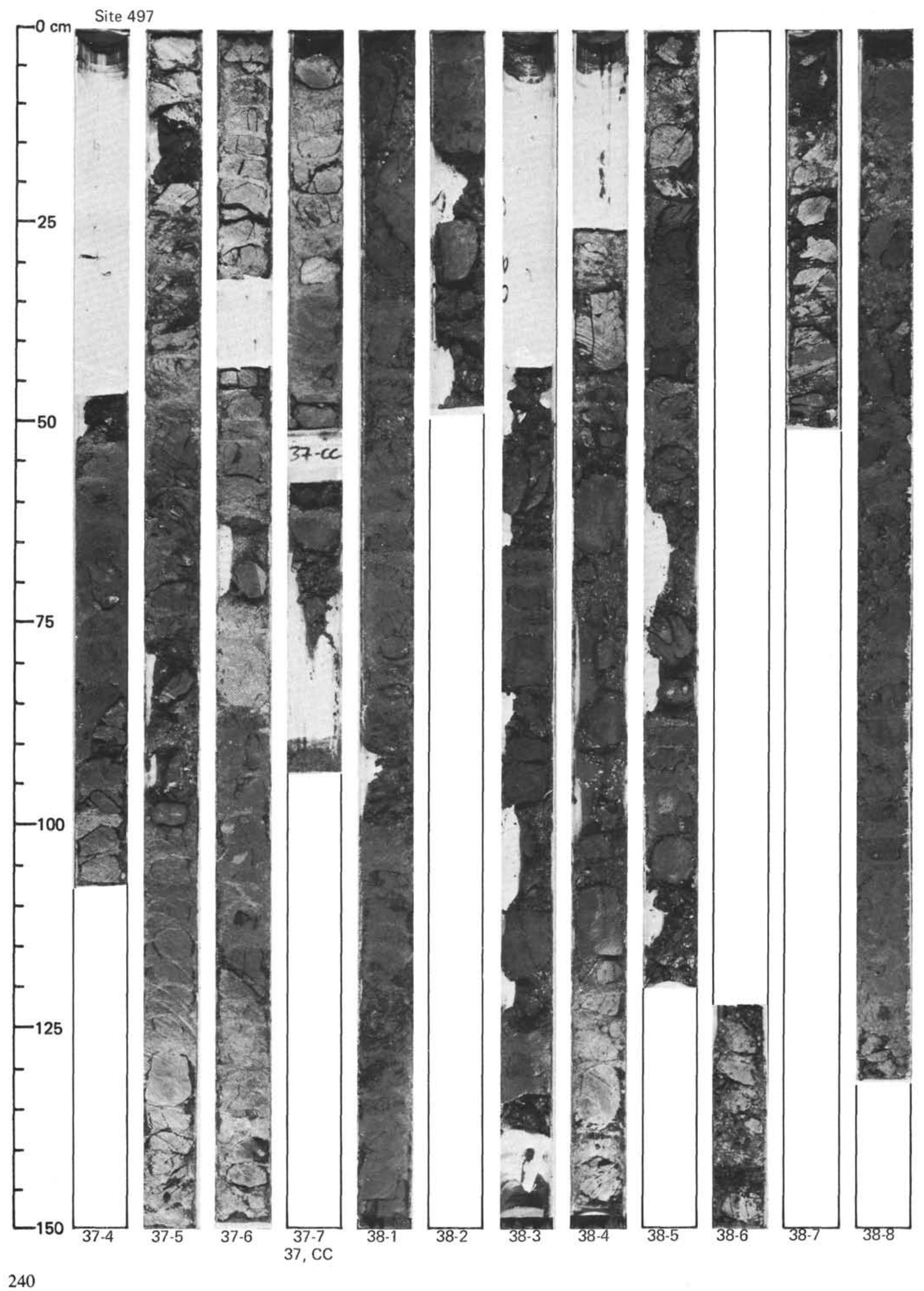



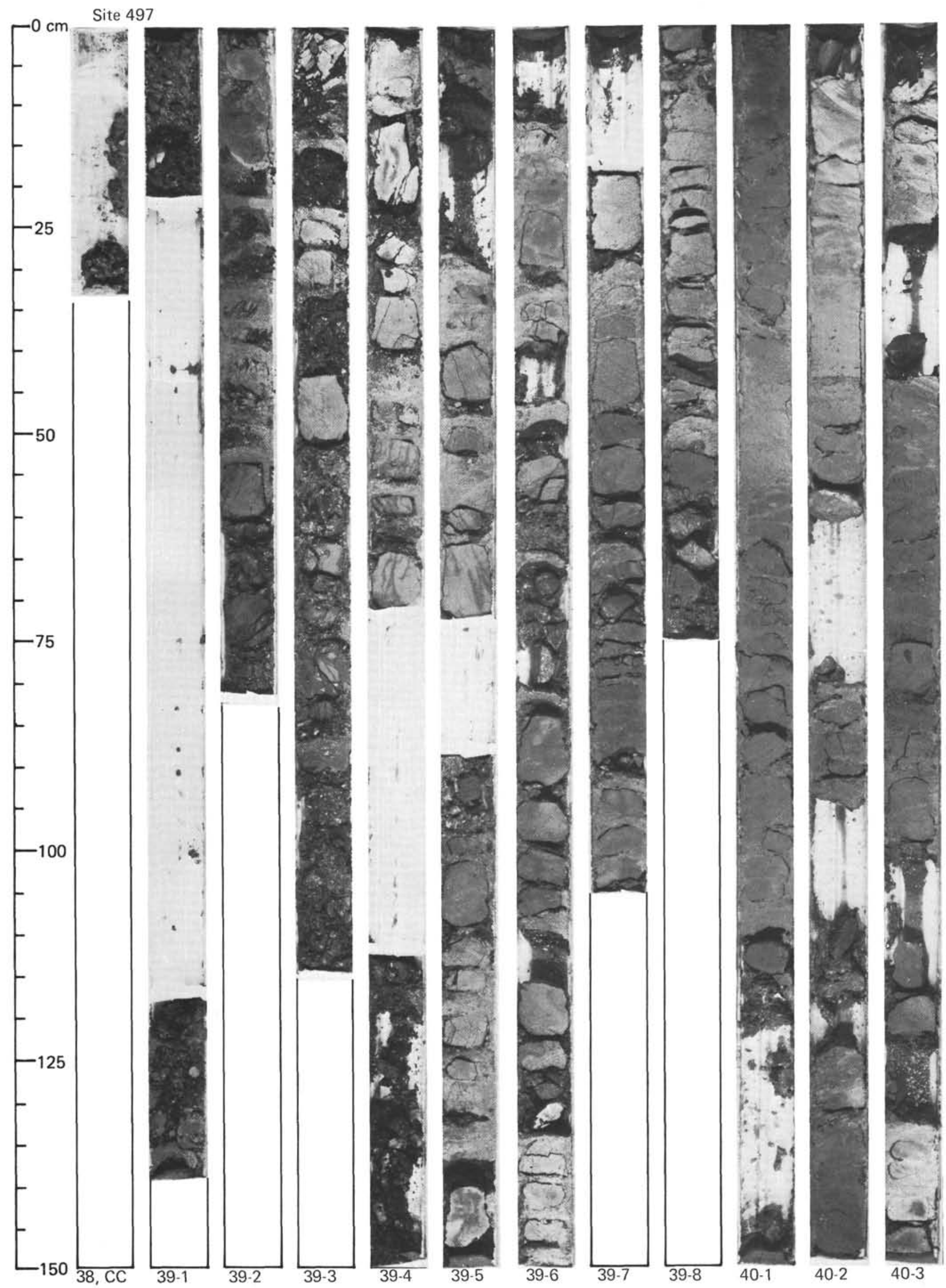


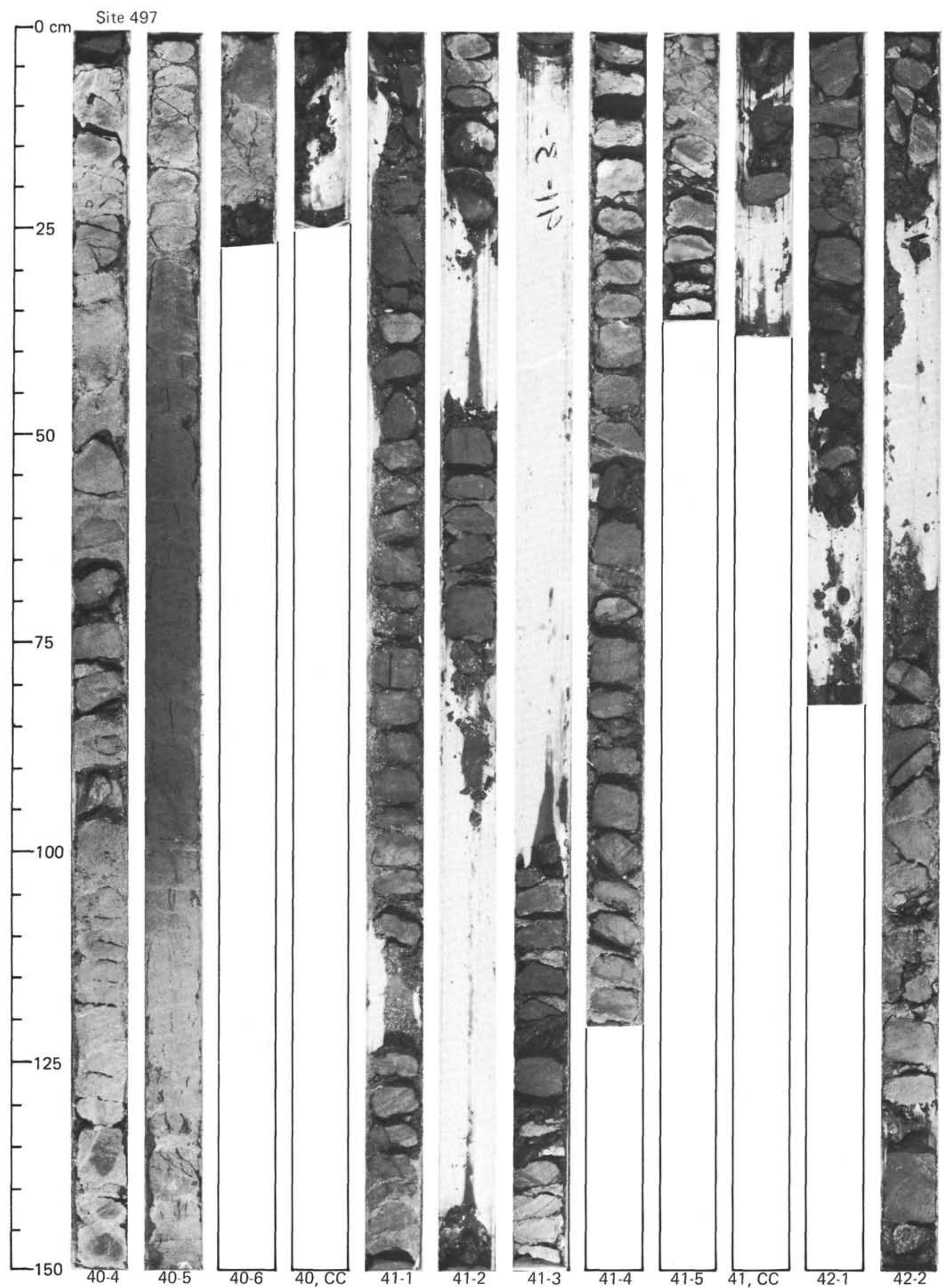



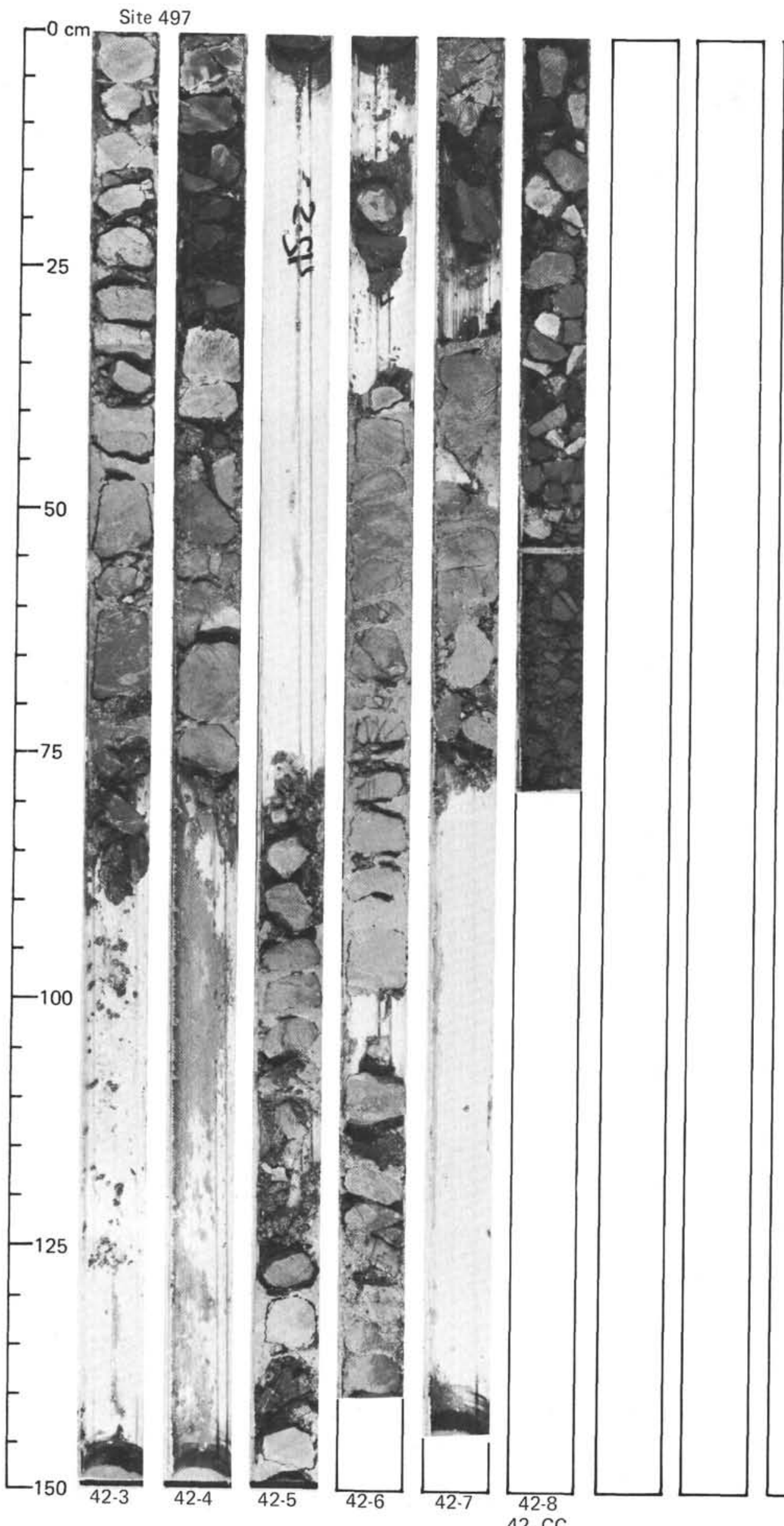